\title{
الوقف كوسيلة فعالة لنهضة المجتمع المسلم
}

\author{
كئية إعداد الدكتور

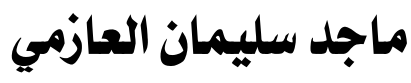

نائب مدير عام بيت الزكاة - دولة الكويت 


\section{الوقف كوسيلة فعالة لنهضة المجتمع المسلم}

$$
\text { قاجد سليمان العازمي }
$$

الملخص:

يتناول هذا البحث الوقف الإسلامي كوسيلة فعالة لنهضة المجتمع المسلم، وقد المدان

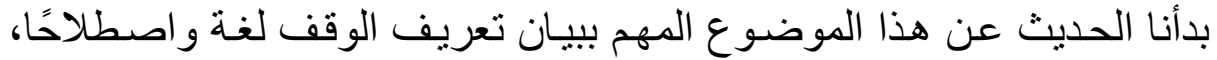

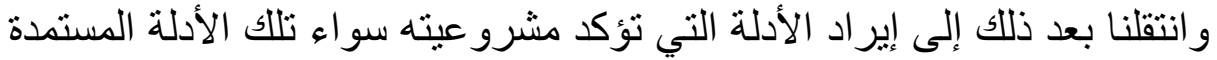

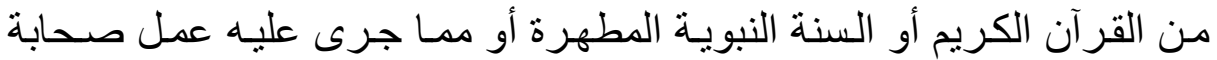

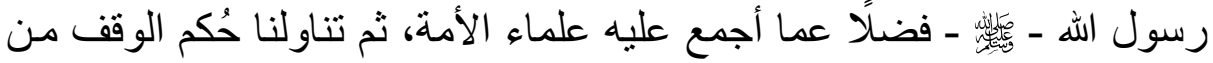

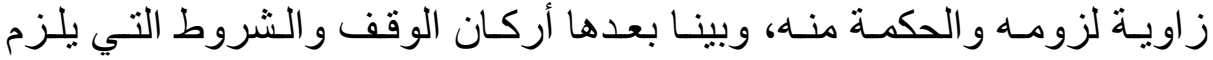

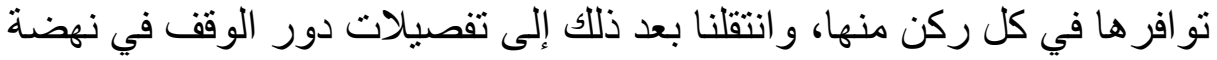

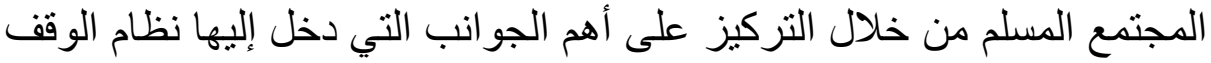

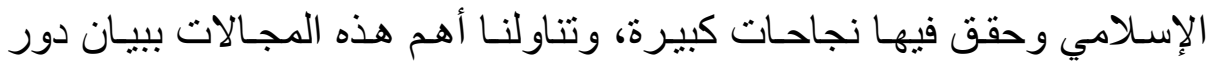

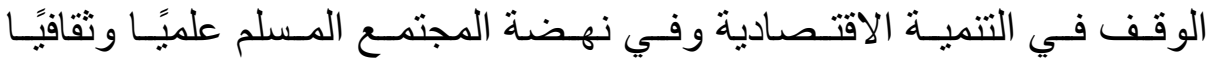

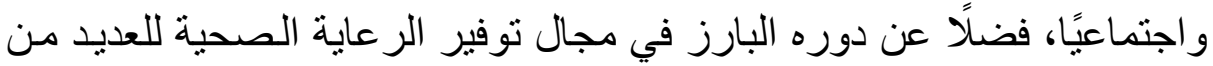
طو ائف المجتمع.

وخلص البحث إلى العديد من النتائج أهمها أن الوقف الإسلامي أثرى حياة

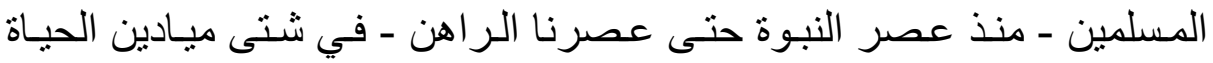
الاقتصادية و العلمية و الثقافية و الاجتماعية و الصحية، وكذللك تبين أنه نظام بتميز

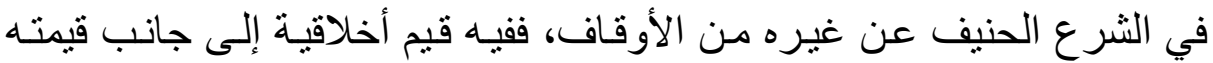
المادية، وفيه الاهتمام بالجانب الديني إلى جانب الناحية الحياتية.

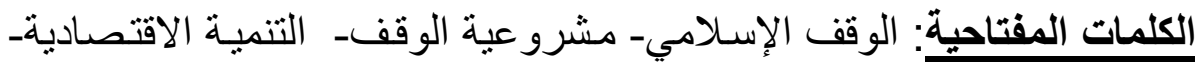
نهضة المجتمع الرعاية الصحية. 
=

الوقف كوسيلة فعلة لنهضة المجتمع المسلم

Endowment as an effective way to revive the Muslim

community

Majed Sulaiman Al-Azmi

Jurisprudence Department - Deputy General Manager of

Zakat House - State of Kuwait

Email: Majed123@yahoo.com

\section{Abstract:}

This research deals with the Islamic endowment as an effective means for the renaissance of the Muslim community, and we started talking about this important topic by explaining the definition of the endowment in language and terminology, and then we moved on to clarify the evidence that confirms the endowment of the endowment, whether those evidence is derived from the Noble Qur'an or the pure Prophet's Sunnah or from what happened He has to do the companions of the Messenger of God, may God's prayers and peace be upon him, as well as what the nation's scholars unanimously agreed upon, then we dealt with the ruling on the endowment from the angle of the obligatory to the endowment and the wisdom from it, and then we clarified the pillars of the endowment and the conditions that are required in every corner, and then we moved to the details of the endowment role in the renaissance of society Muslim through the focus on the most important aspects that entered the Islamic waqf system and achieved a great success, and we dealt with the most important areas of a statement on the role of the endowment in economic development and in the renaissance of the Muslim community scientifically, culturally and socially, as well as a prominent role in the provision of health care for many of the communities of society. 


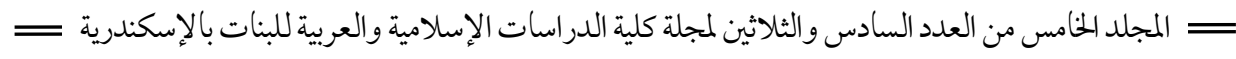

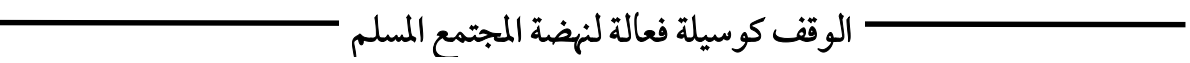

qThe research concluded many results, The most important of them is that the Islamic endowment enriched the lives of Muslims - From the time of the prophecy until our time - In all fields of economic, scientific, cultural, social and health life, It was also found that it is a system that is distinguished in Islamic law from other endowments In this system, moral values as well as its material value, And it has an interest in the religious aspect Beside Life aspect.

Keywords: Islamic endowment - endowment legitimacy economic development - community renaissance health care. 


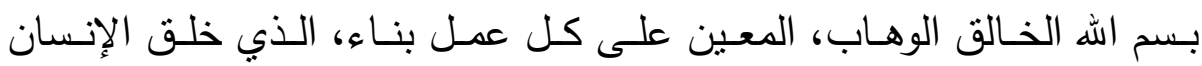

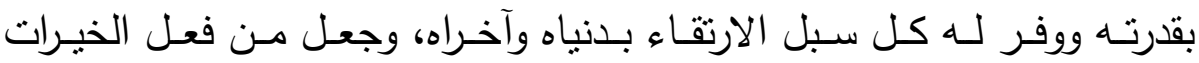
تطهيرًا لنفسه من الزلل ومواطن النقص رفعًا لثأنه في الدنيا والأخرة.

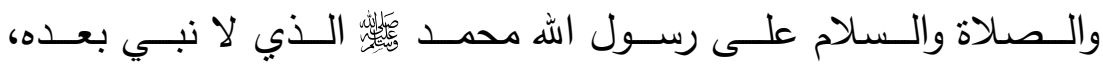

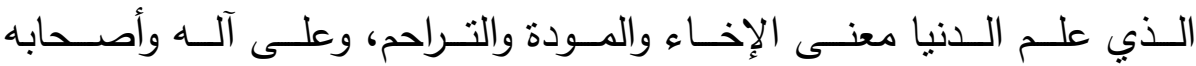
الأطهار الطييين، الذين اقتتوا به وساروا في هديه حتى أناهم اليقين.

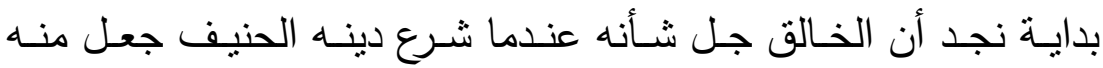

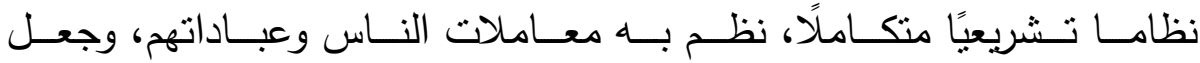

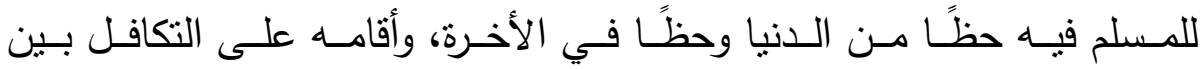

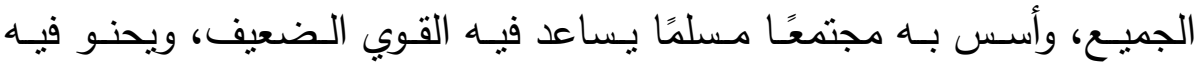

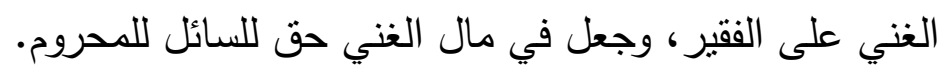

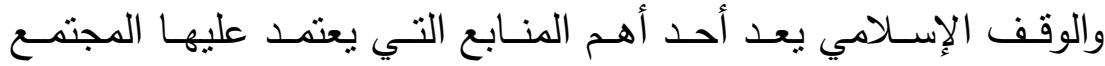

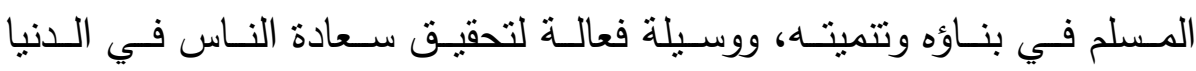
والأخرة، وهو شعيرة من أجل الثعائر وأعظمها.

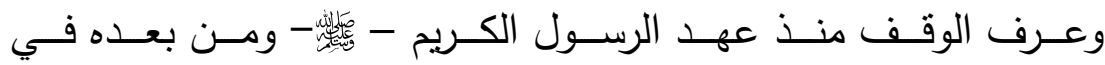

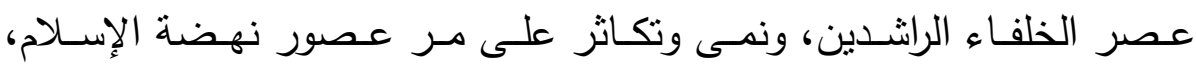

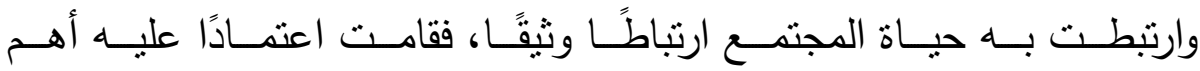

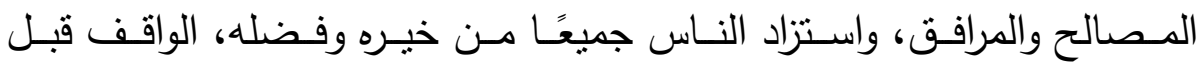

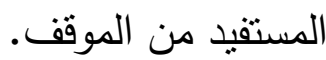

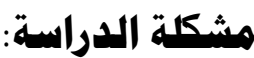

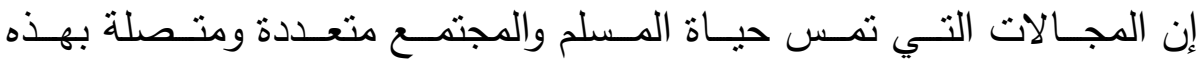

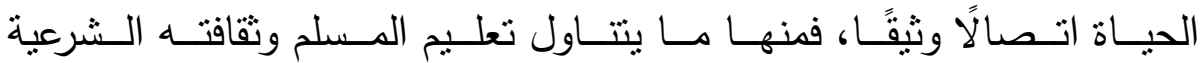


والدنيويـة، ومنهـا مـا يتتـاول حياتـه الـصحية، إضـافة إلـى ظروفـه المعيـثية والاقتصادية والاجتماعية وغير ذلك. وملائ.

وهـذه المجـالات جميعًا تحتـاج إلـى نفقـات كبيـرة، ولا يمكـن أن يتـرك

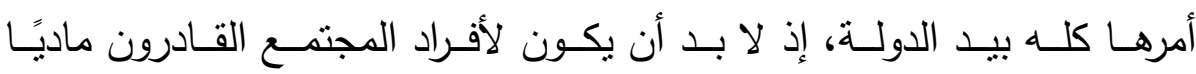

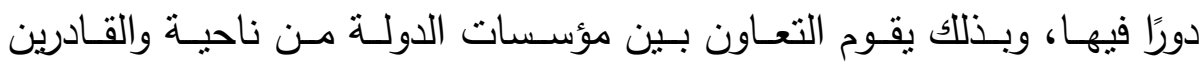

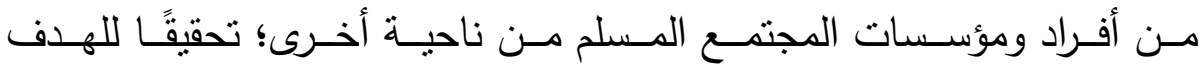

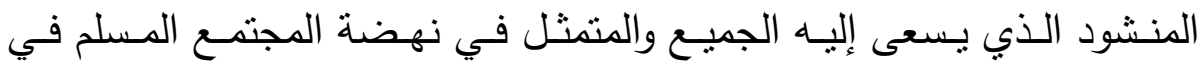
شتى جوانب حياته.

على مـا تقدم؛ فـإن مسثكلة الدراسـة تتمثل في النفقات الباهظـة التي

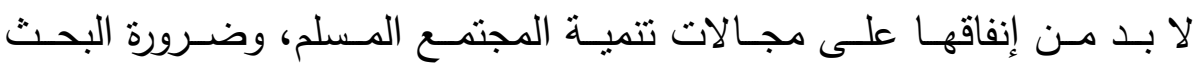
عن ألية مناسبة لتمويل هذه النفقات.

ويمكـن إجمـال الإشـكاليات التـي تثيرهـا الدراسـة المانلــة فـي صــورة بعض التساؤلات، وذللك على الوجه التالي:

1- مـا هـو مفهوم الوقف الإسـلامي ومـا هـي أدلـة مـشروعيته، والحكمـة من تقريره؟

r- ما هي الأركان التي لا يتصور قيام الوقف بغيرها؟

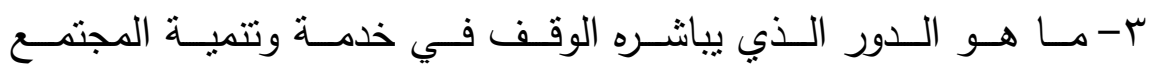

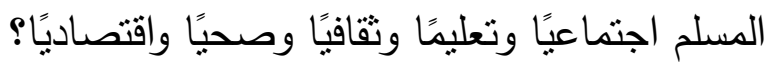

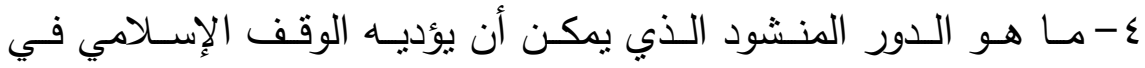
تمويل مشروعات التتمية المجتمعية؟ هئ

لأهميـة نظـام الوقـف الإســلامي فقـد عنـي بدراسـات وتحلـيلات وشـروحات

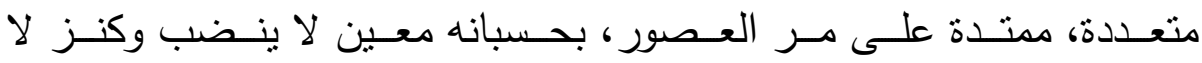

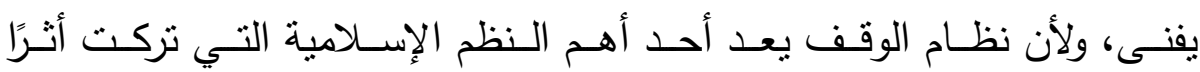

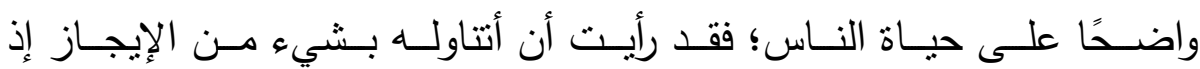
الحديث فيه يطول ولا ينتهي. 


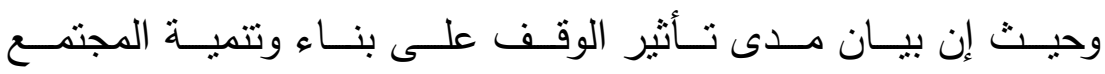

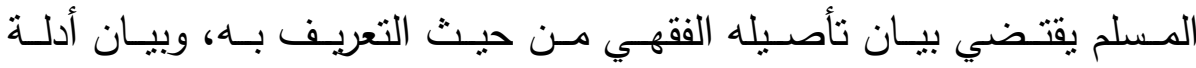

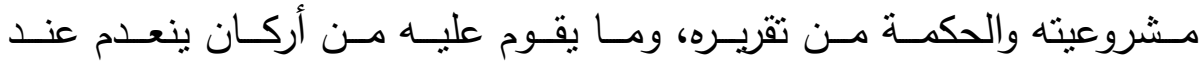

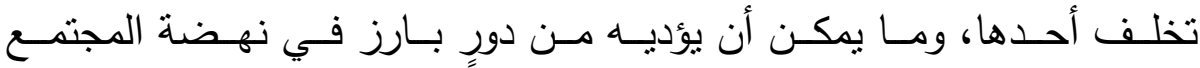

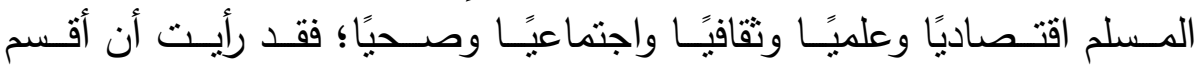

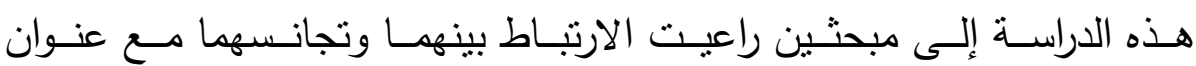

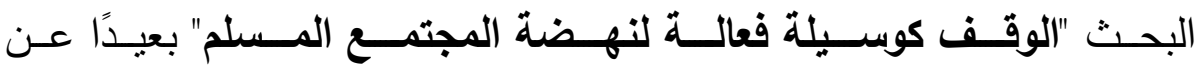

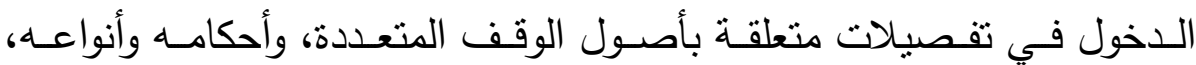
مما لا يتماس مع عنوان موضوعنا، وذللك كله على الوجه التالي:

\section{المبحث الأول : التأصبل الثقهي للوقث}

المطلب الأول: تعريـف الوقـف ويــان مسشروعيته وحكمـه مـن زاويـة لزومه وحكمته. المطلب الثاني: أركان الوقف وشروطها. المبحث الثاذي : دور الوقف في ذهضلة المجتمع المسلم. المطلب الأول: الوقف والتنمية الاقتصادية. المطلب الثاني: الوقف والنهضة التعليمية والثقافية. المطلب الثالث: الوقف والارتقاء بالحالة الاجتماعية. المطلب الرابع: دور الوقف في توفيز الرعاية الصحية.

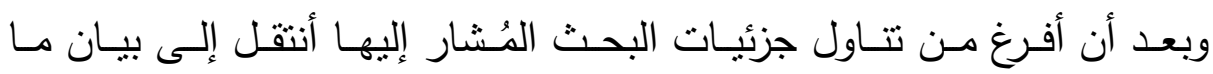

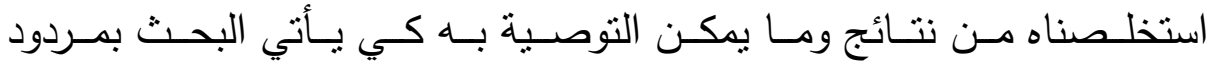
إيجابي على المجتمع. - اهن.

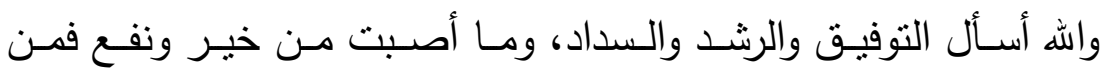

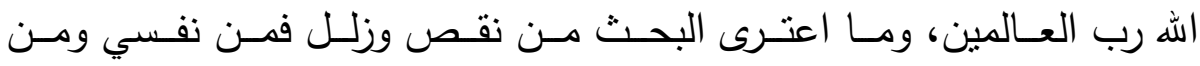
الثيطان 


\title{
البمحث الأول \\ التأصيل الفقهي للاوقف
}

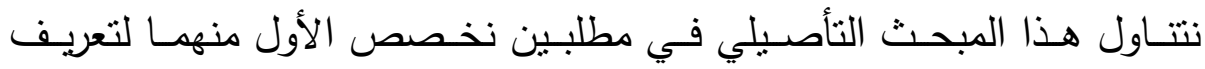

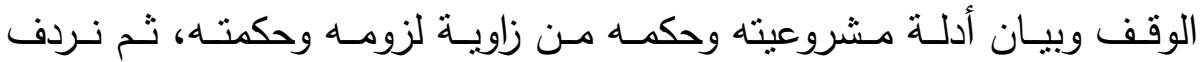

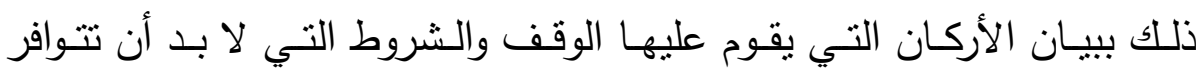
فيها، وذللك في المطلب الثاني.

\author{
المطاب الأول \\ تعريف الوقف وبيان أدلة هشروعيته \\ وحكمه هن زاوية لزوهه وحكمته \\ ونتتاوله في ثلاثة فروع على النحو التالي: \\ 1- في التعريف بالوقف.

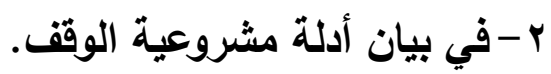 \\ r- في حكم الوقف من زاوية لزومـه وحِكته.
}




\section{الفرع الأول}

\section{في التعريف باللوقف}

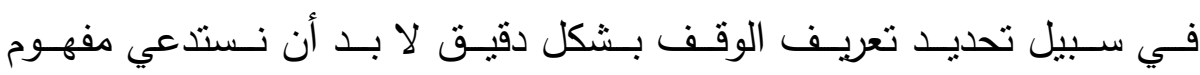
الوقف في اللغة ومفهومه في اصطلاح الفقهاء

\section{أولًا - تعريف الوقف في اللغة:}

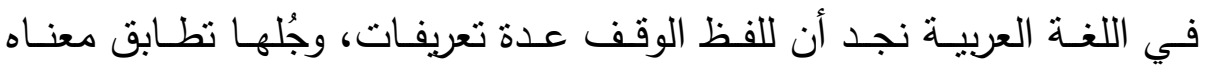

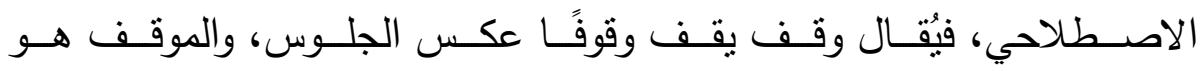
موضع الوقوف، ووقف بمعنى سكن ولم يتحرك من مكانه (').

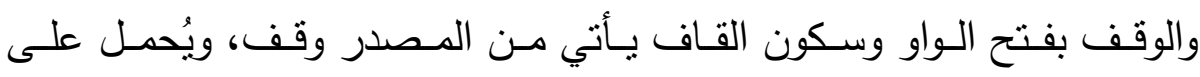

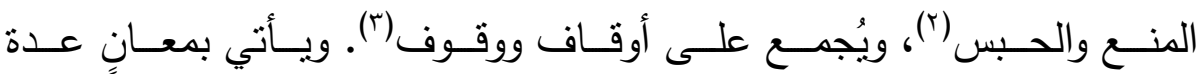

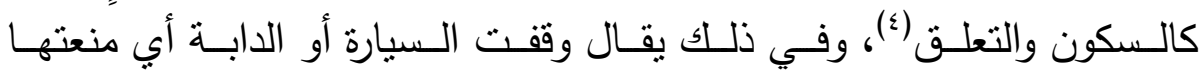

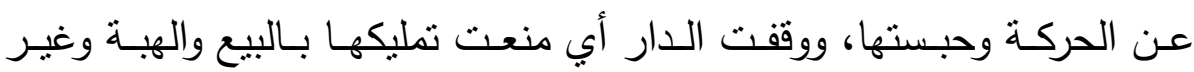

( (1) د. عكرمة سعيد صبري، الوقف الإنسلامي بين النظرية والنطبيق، دار النفائس للنشر

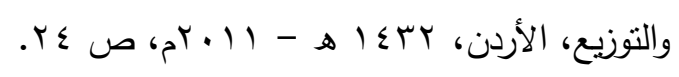

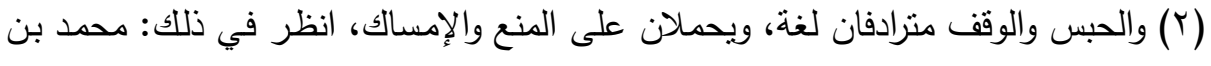

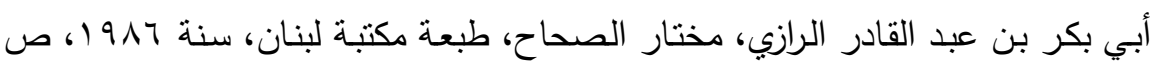

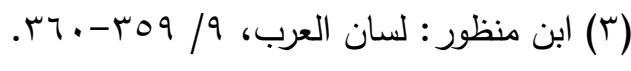

(ع) كامل محمد حسين حامد، اثر الوقف في دعم وتطوير التعليم الشرعي وتطبيقاتها

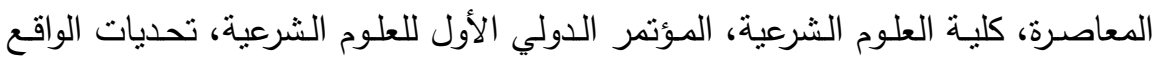

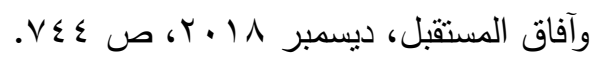




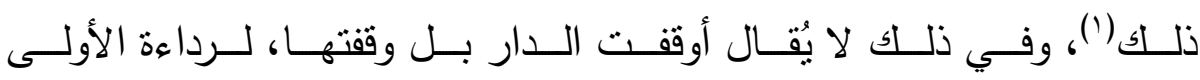
وشذوذها لغة)(ب)

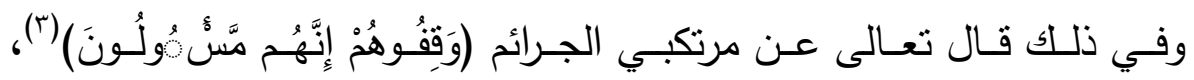

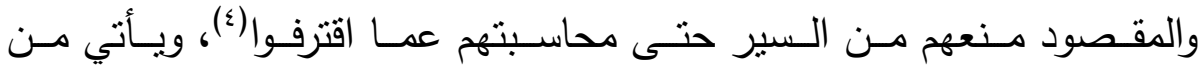

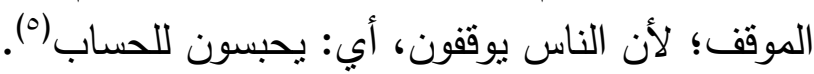

\section{ثانيًا - تعريف الوقف في الاصطلاح:}

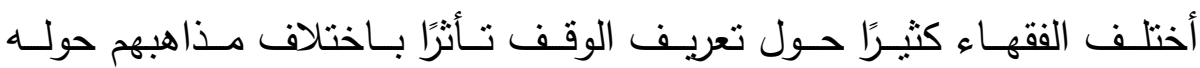

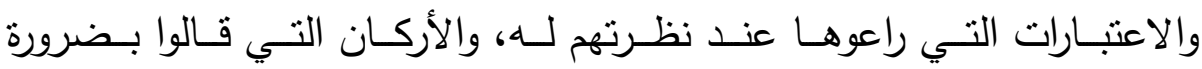

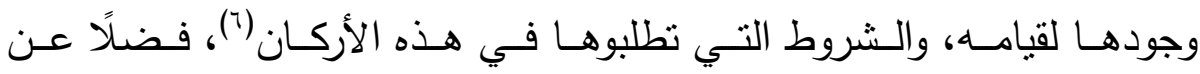

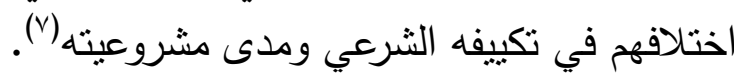

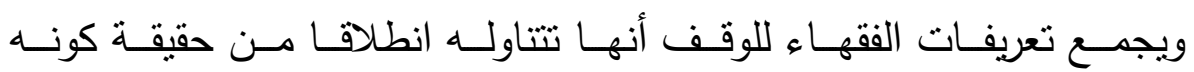

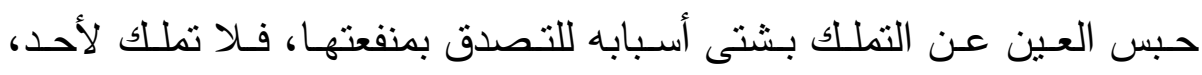

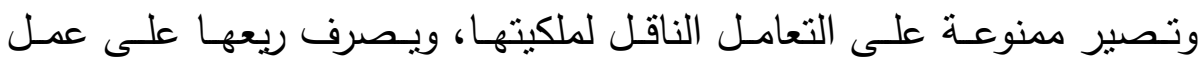

( (1) د. محمد حفني يوسف، أحكام الوصية والوقف في الفقه الإسلامي والقانون، دراسة فقهية كانية

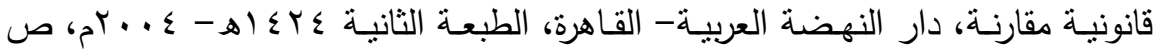

(0) برهان الدين إبراهيم موسى علي الطرابلسي، الإسعاف في أحكام الأوقاف، دار الرائد

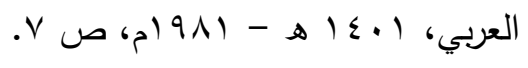

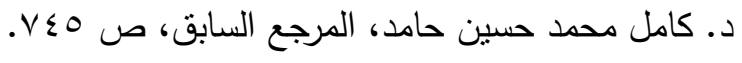

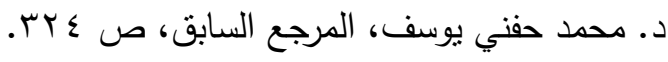




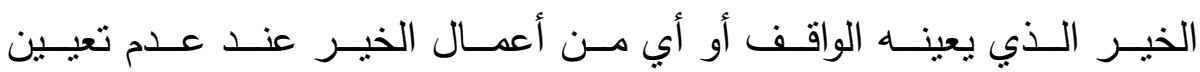
الواقف لعملٍ بعينه (').

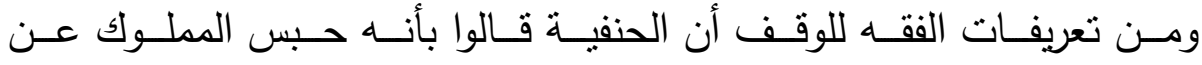

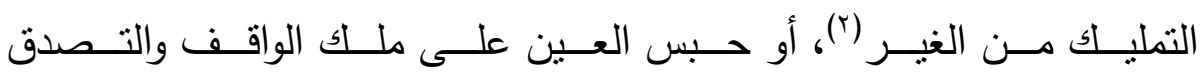

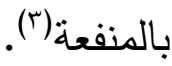

وعلى مـا تقدم بمكن تعربـف الوقف بأنـه "حبس العـين عـن التصرف فيهـا

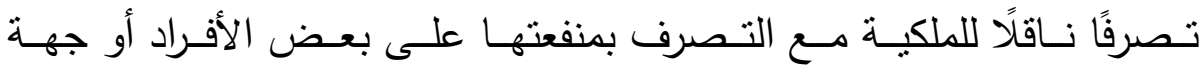

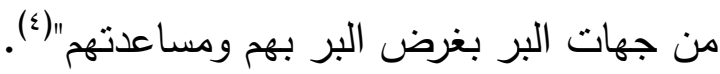

(1) الإمـام محمد أبو زهرة، محاضرات في الوقف، دار الفكر العربي بالقاهرة الو9 (، ص

(Y) محمد بن أحمد بن أبي سهل السرخسي، المبسوط، دار المعرفة، بيروت، ب99 ام، ج (r)

(r) زين الدين بن إبراهيم بن محمد بن نجيم، البحر الرائق شرح كنز الدقائق، دار الكتب

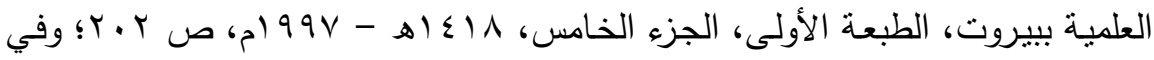
مزيدٍٍ من تعريفات الفقهاء للوقف اصطلاحًا، أنظر : د. عكرمسة سعيد صبري، المرجهع

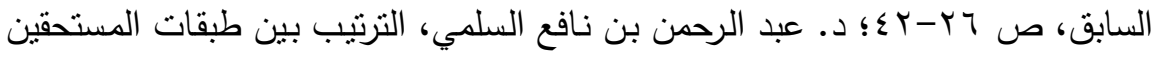
للوقف في الفقه الإسلامي، دراسة فقهية مقارنة تطبيقية على أحد صكوك القضايا الصادرة

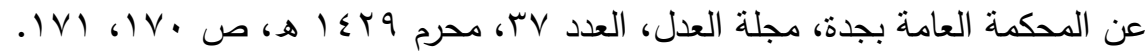

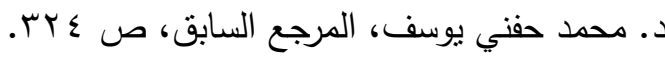




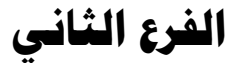

\section{أدلة مشروعية الوقف}

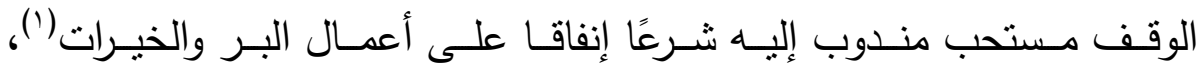

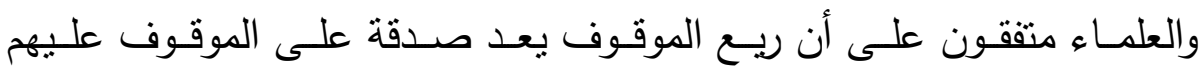

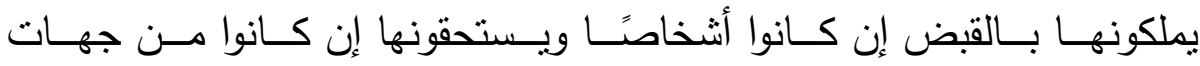

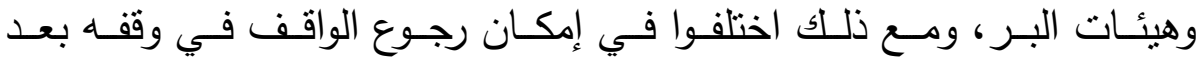

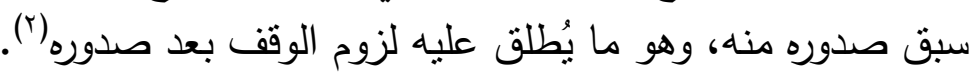

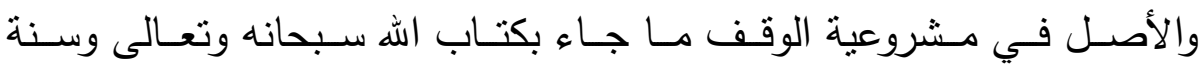

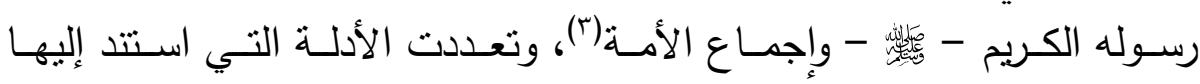
الفقهاء في القول بمشروعية الوقف، وذللك على التقصيل التالي:

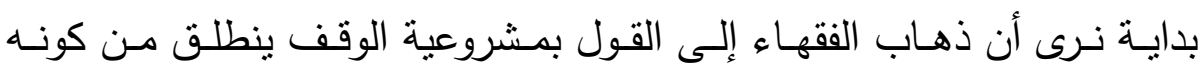

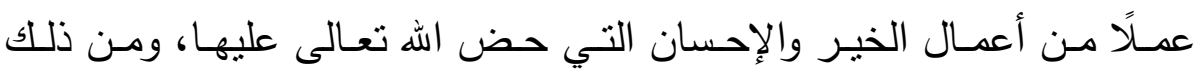

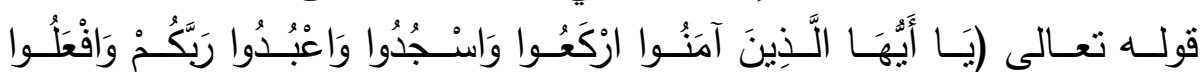

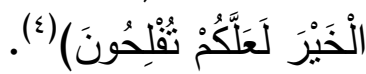

(1) عبد الله بن أحمد بن محمد بن قدامة المقدي، المغني، الجزء الثامن، دار عالم الكتب،

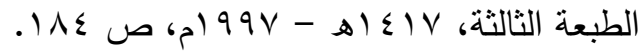

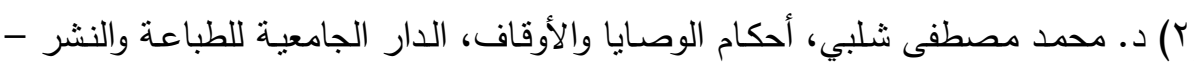

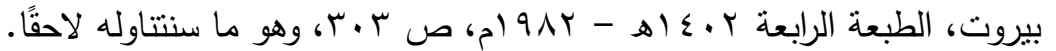

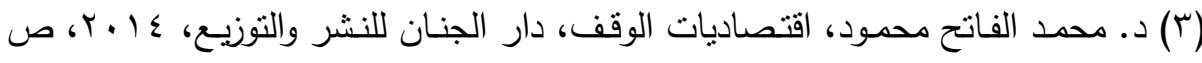
1ا؛ بل إن الوقف على معناه المقصود في ديننا الحنيف عُرف منذ أزمان بعيدة سابقة

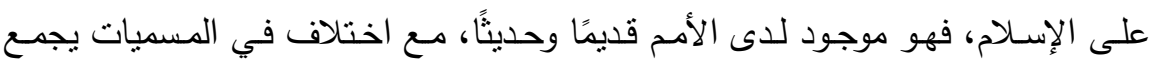

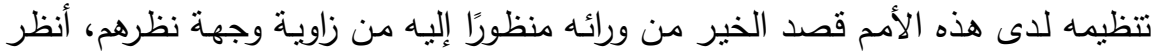

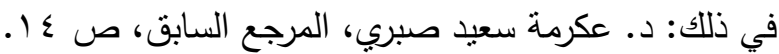

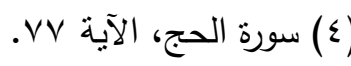




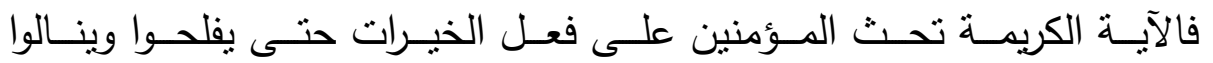

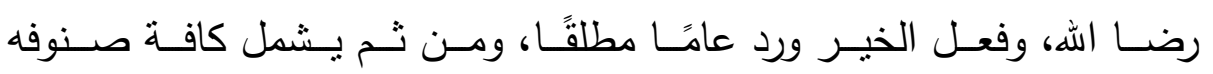

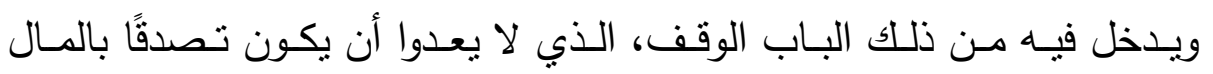
خدمة لمصالح مشروعة ومساعدة على البر (').

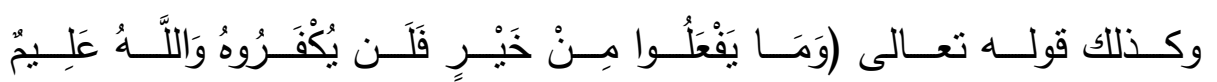

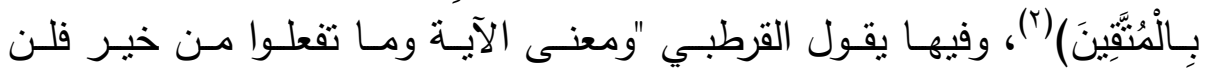
تجحدوا ثوابه بل يشكر لكم وتجازون به"("). وفئ.

أولَا- أدلة مشروعية الوقف من القرآن الكريم:

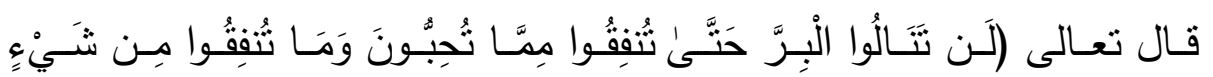

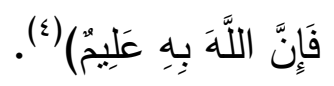

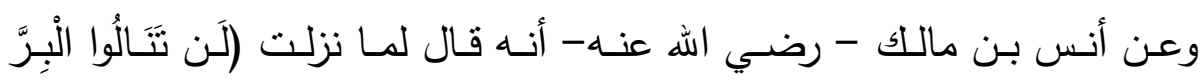

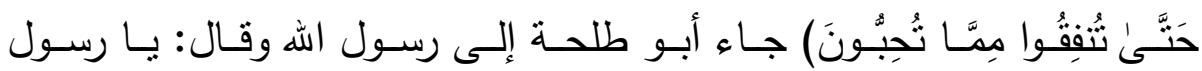

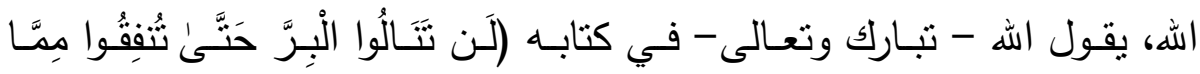

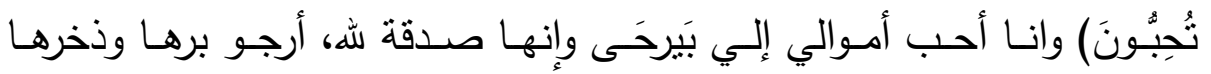

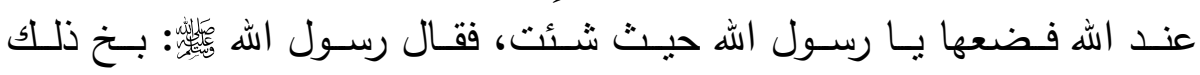

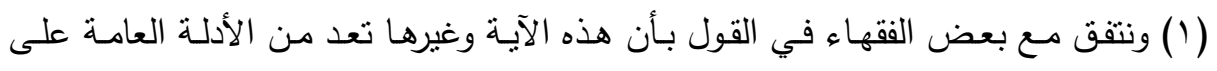

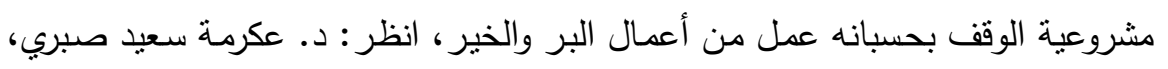

$$
\begin{aligned}
& \text { الوقف، المرجع السابق، ص ع ــ }
\end{aligned}
$$

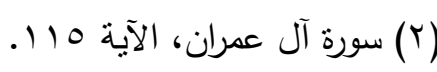

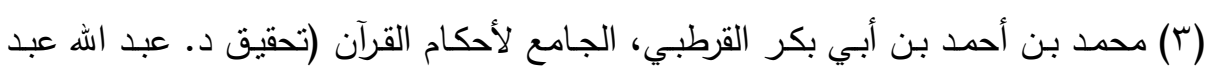

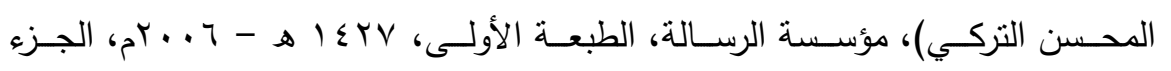

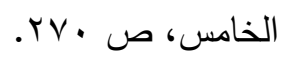

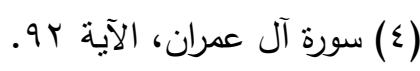




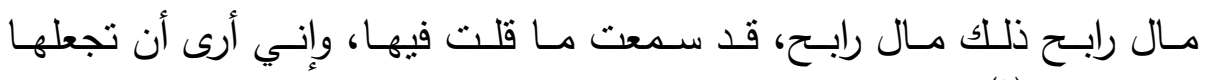
في الأقربين (').

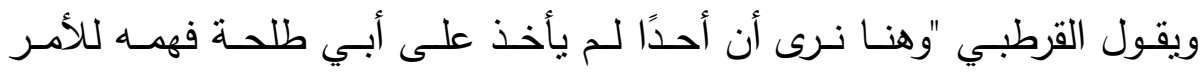

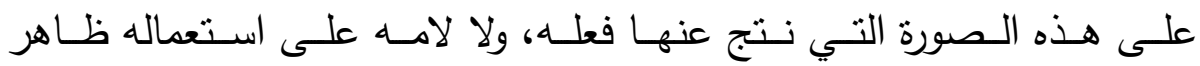

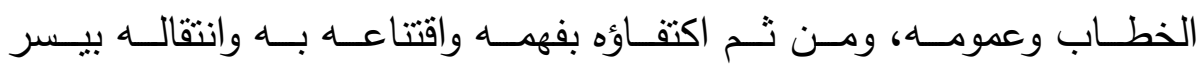

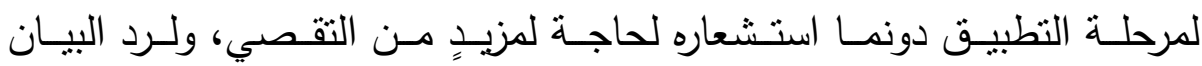

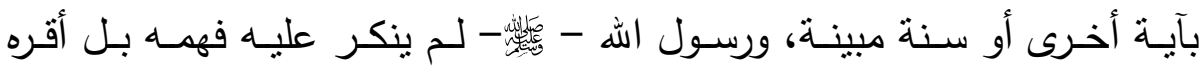

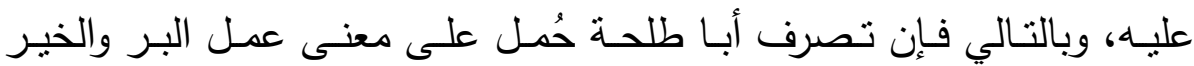

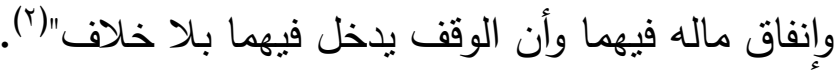

\section{ثانيًا - أدلة مشروعية الوقف من السنة النبوية:}

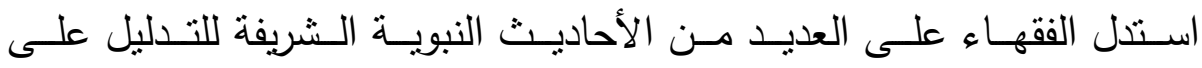

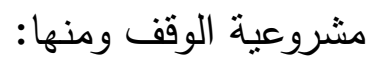

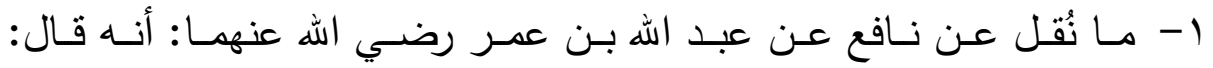

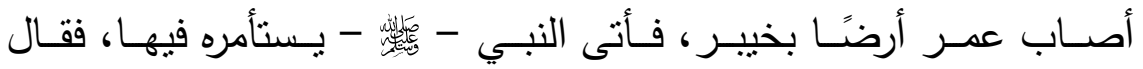

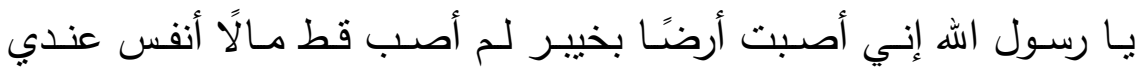

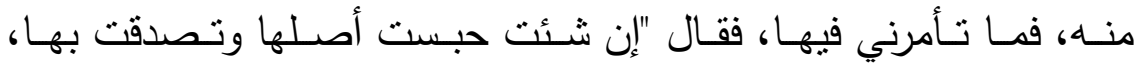

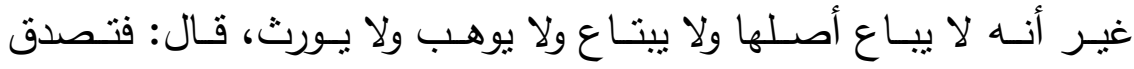

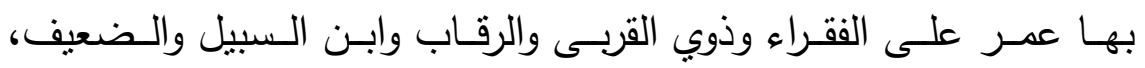

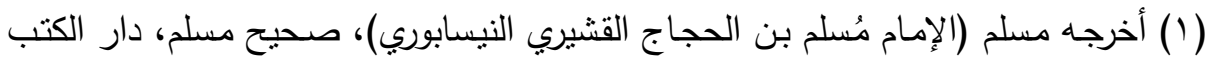

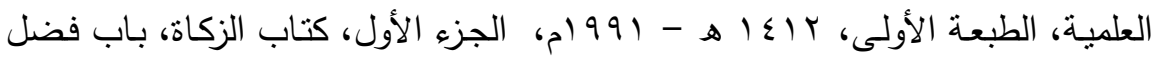
النفقة والصدقة على الأقربين والزوج والأولاد والوالدين ولو كانوا الهوا مشركين، رقم $991 ،$ 


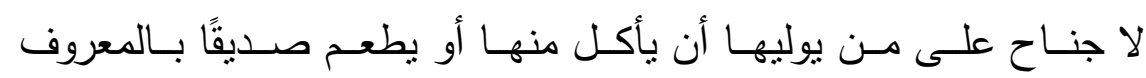

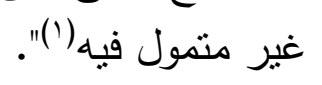

والحـديث الـشريف المتقـدم يـضع القواعـد الأصـولية للوقف، ويبـين ماهيتهـ، ويرده إلى الصدقات، وبالتالي يقيم نظامه على أساس منين.

Y- عـن ابـن عبـاس رضـي الله عنهمـا أن سـعد بـن عبـادة رضـي الله عنـهـ

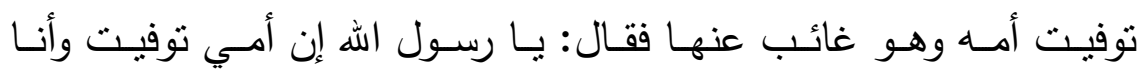

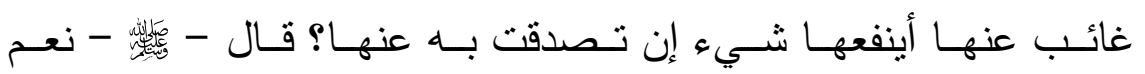

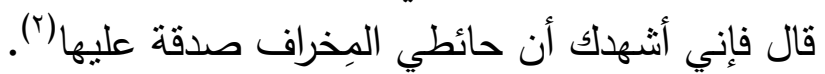

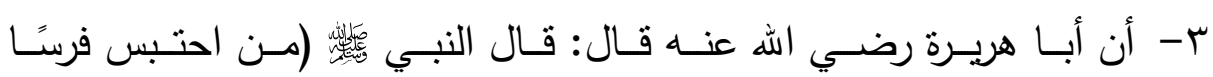

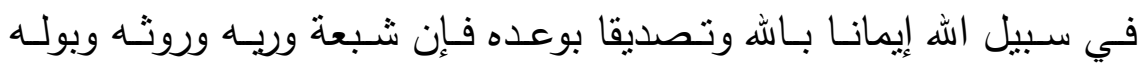

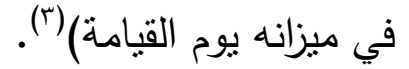

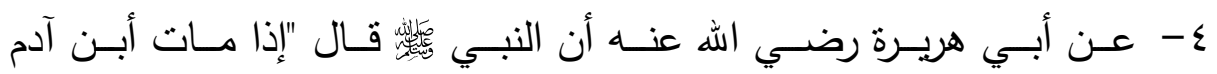

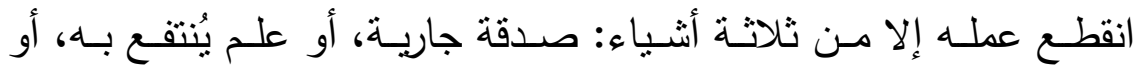

$$
\text { ولد صالح يدعو لله (أ)". }
$$

(1) محمد بن علي بن محمد بن عبد الله الصنعاني الشوكاني، نبل الأوطار شرح منتقي

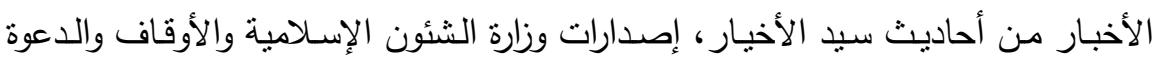

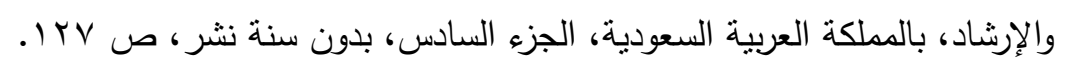

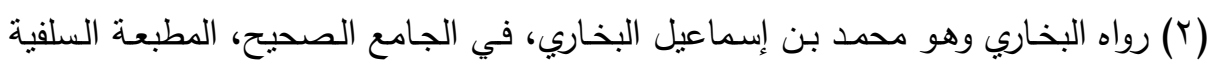

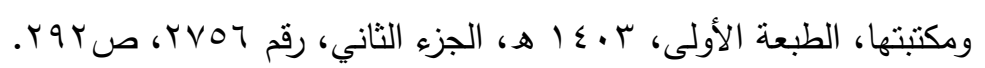

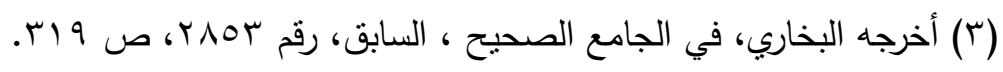

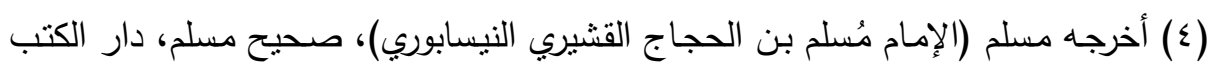

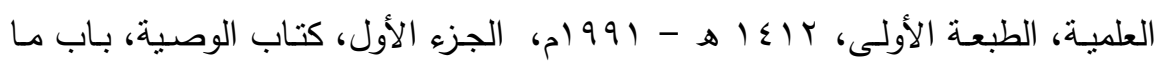

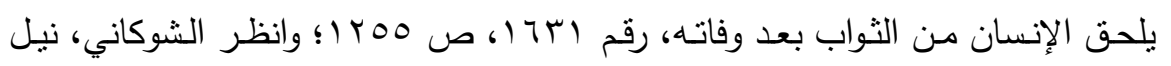

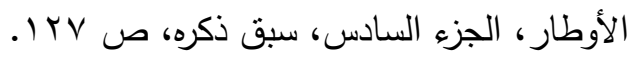




\section{ثالثًاً - الإجماع على مشروعية الوقف:}

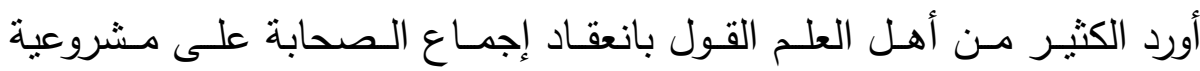

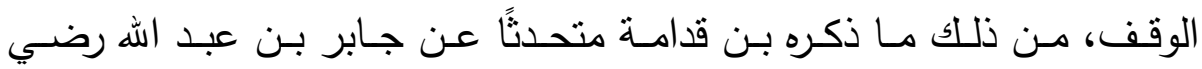

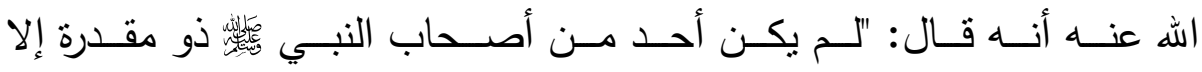

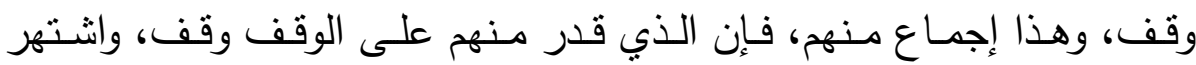

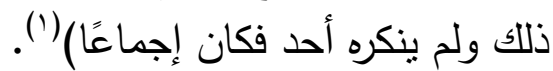

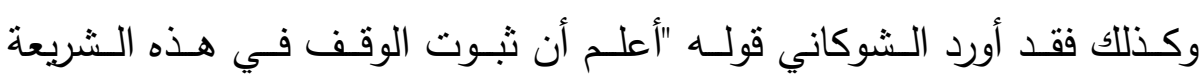
وثبوت كونه قربة أظهر من شمس النهار "(r).

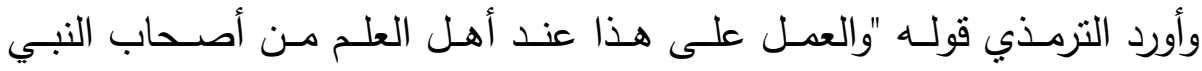

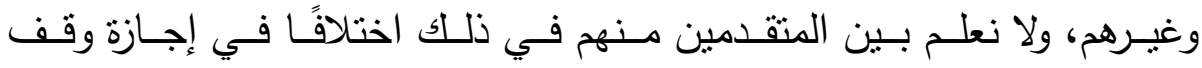

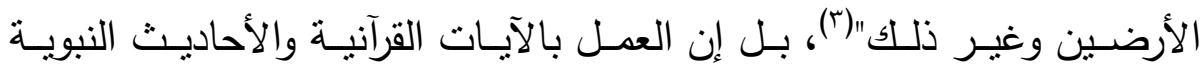

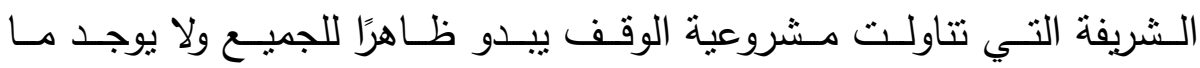

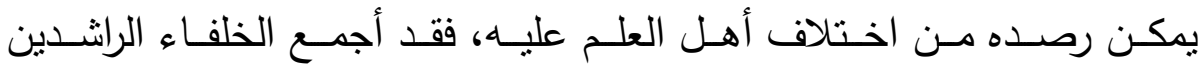

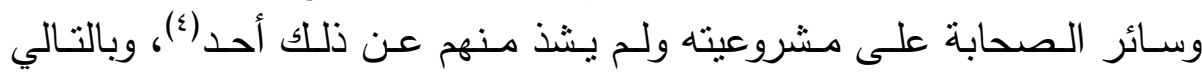

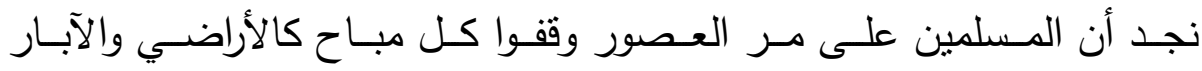

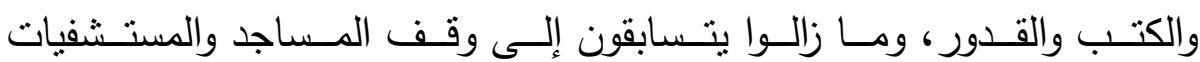

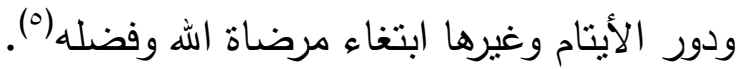

(1) عبد اله بن أحمد بن محمد بن قدامة المقسي، المغني، المرجع السابق، ص بـ1 ا.

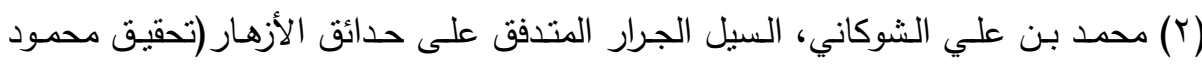

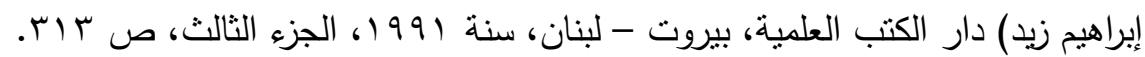

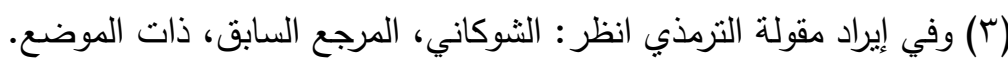

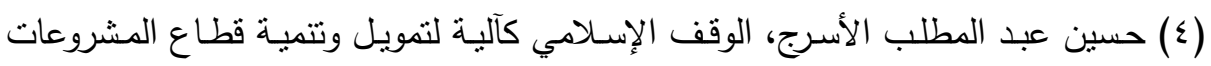

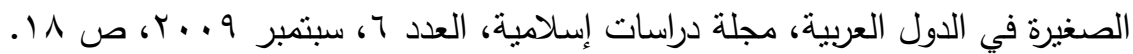

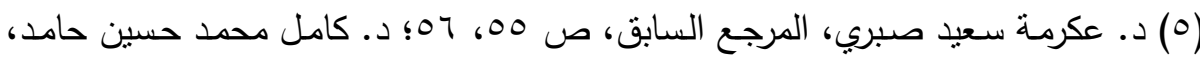

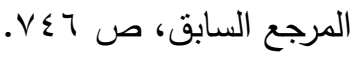




\section{هكم الهقف هن زاوية للزومهه والمكمة هنه}

حكم الوقف من زاوية لزومه:

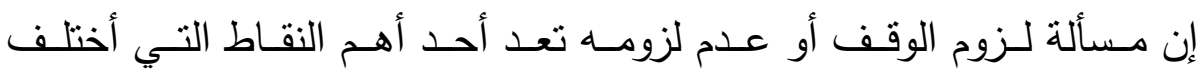

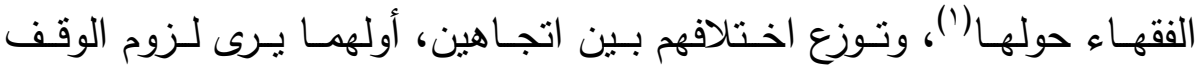

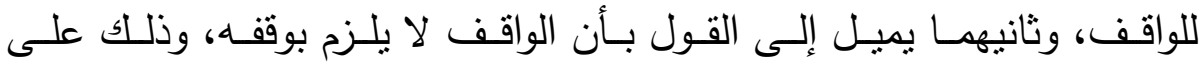
النحو التالي: - n

الـــرأي الأول: وفيـهـ جمهــور الفقهــاء مــن المالكيــة والـشافعية والحنابلــة

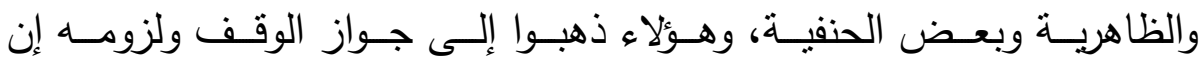
صدر (ץ)، وبالتالي ليس للواقف حق الرجوع فيه بمجرد صدوره عنه (ॅ).

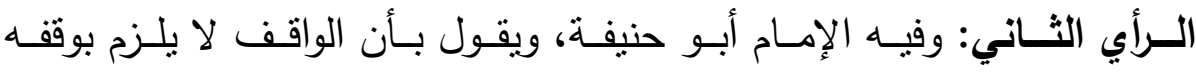

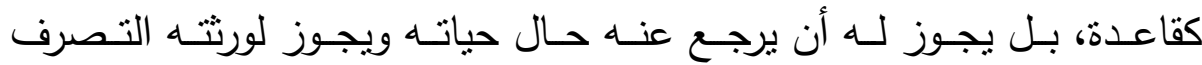

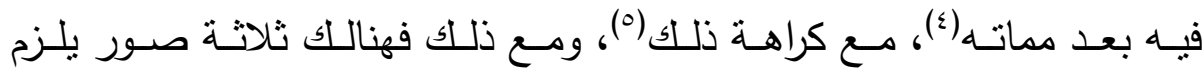

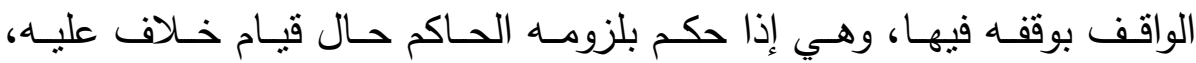
أو في حسال علـق الواقف وقفه على موتـه فهنـا يأخذ الوقف حكم الوصـية

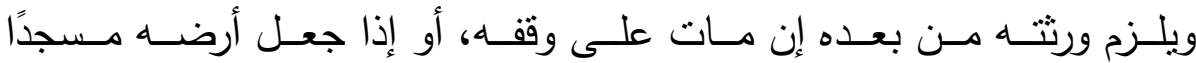

$$
\begin{aligned}
& \text { (1) د. محمد مصطفى شلبي، المرجع السابق، ص م • ؟ّ. } \\
& \text { د. دحمد حفني يوسف، المرجع السابق، ص OY OY. }
\end{aligned}
$$

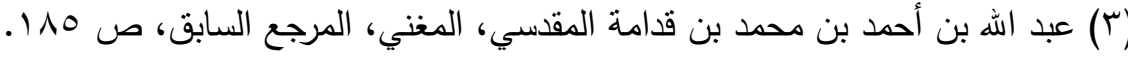

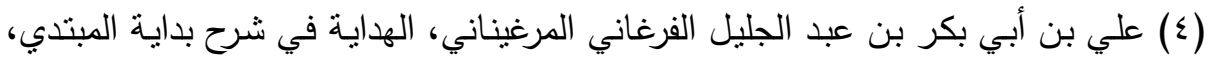
دار إحياء التراث العربي، بيروت، الجزء الثالث، ص 10.

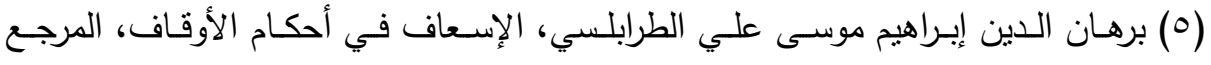

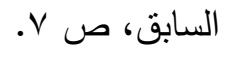




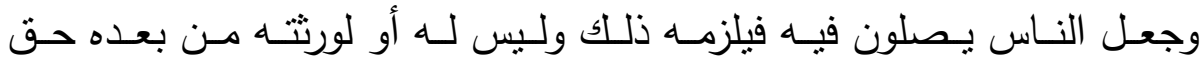

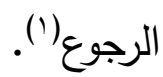

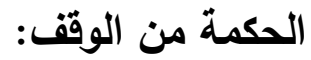

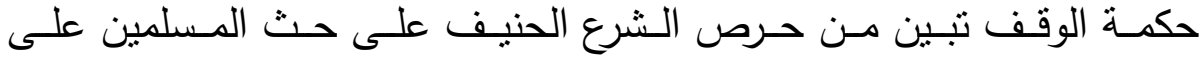

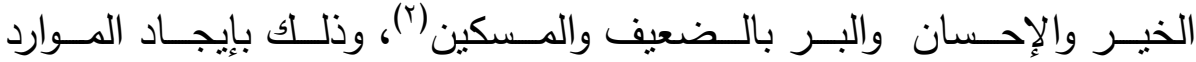

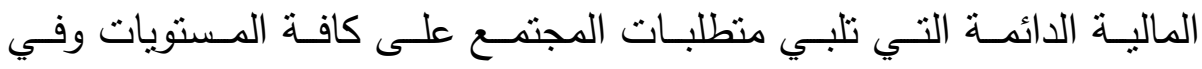

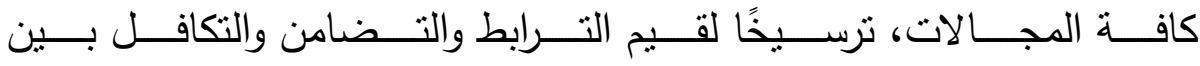

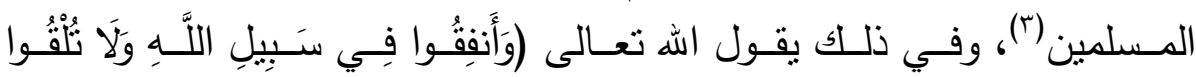

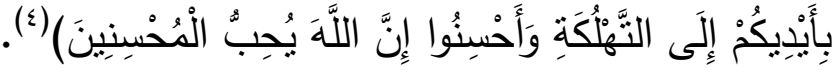

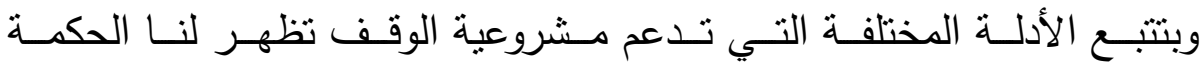

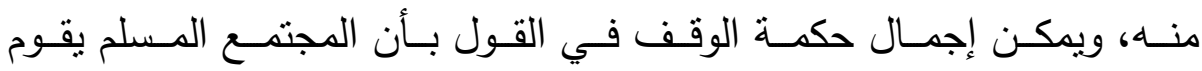

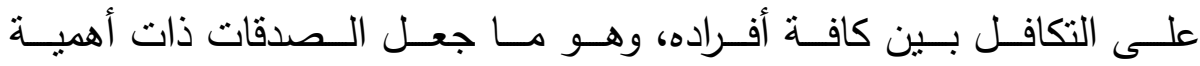

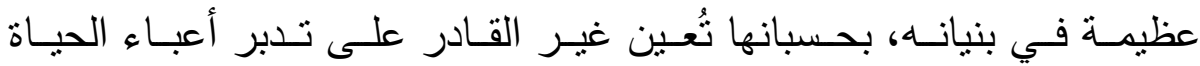

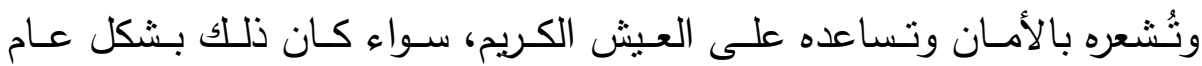

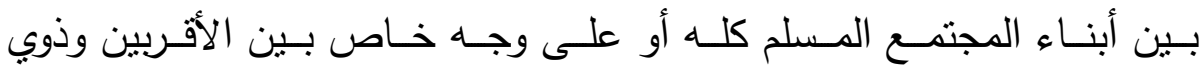

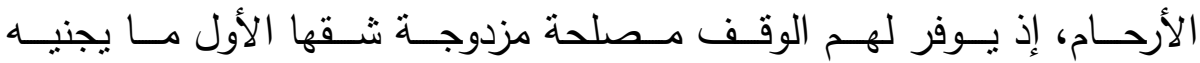

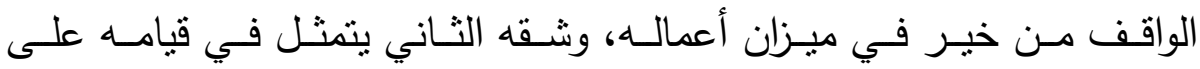
رعاية أقاربه وتقوية صلته بهر.

(1) في شرح ذلك وبيات تفصيلات تلك الصور الثلاثة راجع: د. محمد مصطفى شلبي،

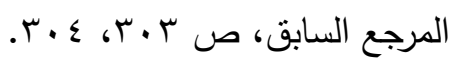

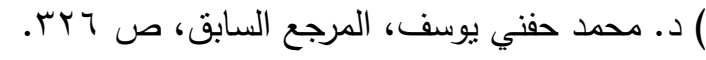

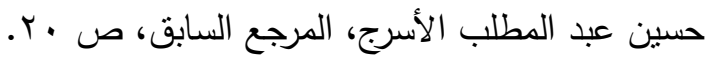




\section{الامطلب الثاني}

\section{أركان الوقف وشروطها}

أختلـف الفقهـاء فـي بيـان أركـان الوقـف، فبعـضهم يـرى أن للوقـف أربعـة

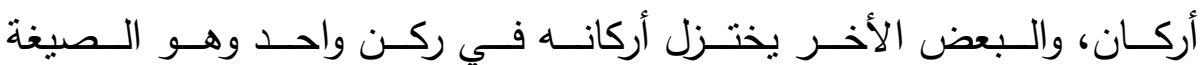

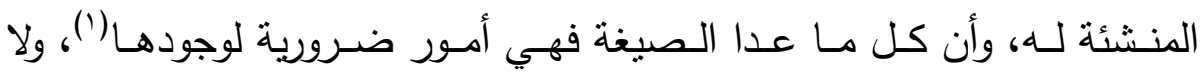

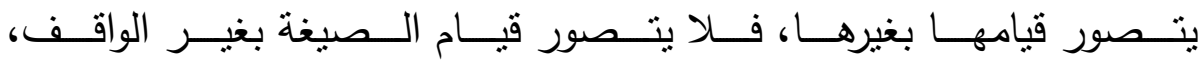

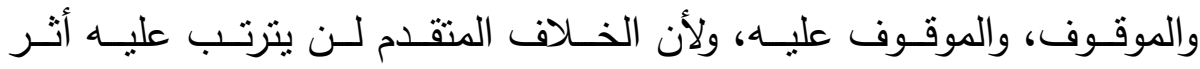

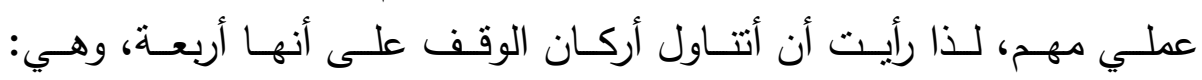

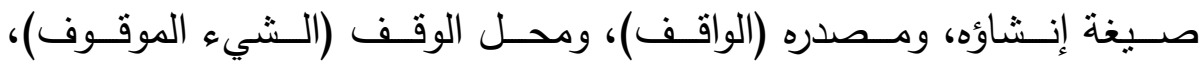

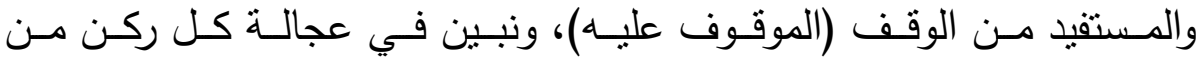

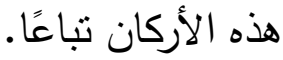

أولًا - صيغة الوقف:

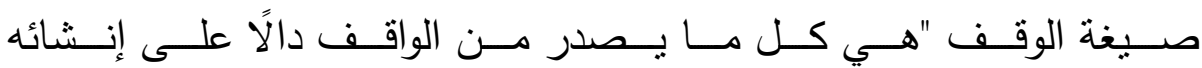

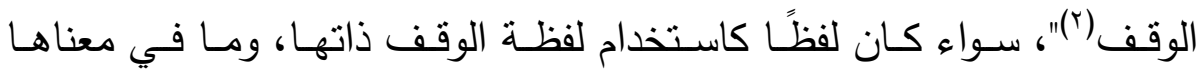

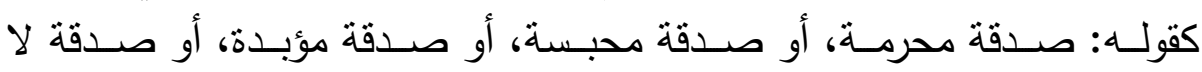

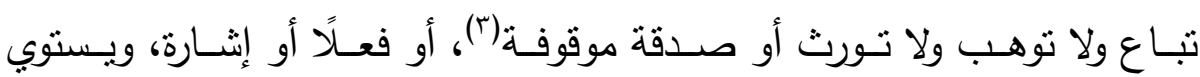

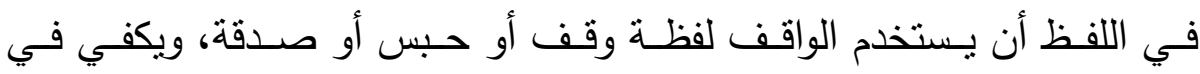

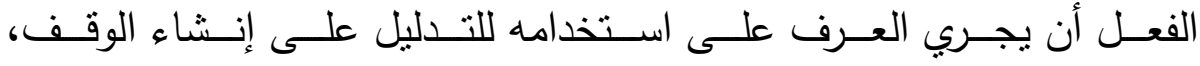

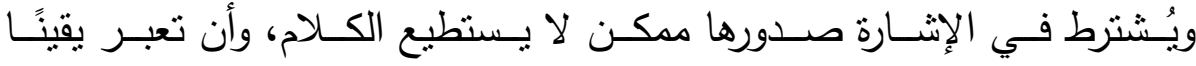

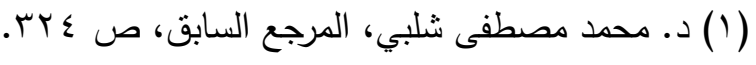

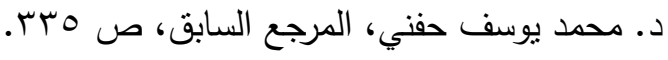

(ץ) برهـان الـين إبراهيم موسى علي الطرابلسي، الإسـعاف في أحكام الأوقاف، المرجـع

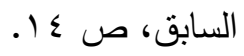




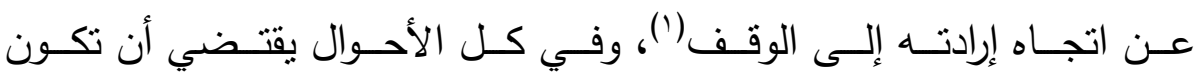

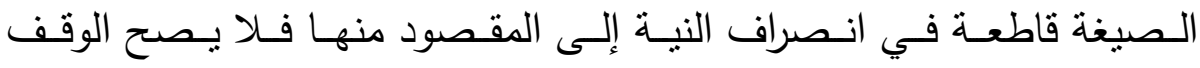
بغير صيغة أو بصيغة تحنمل التأويل واللبس (؟).

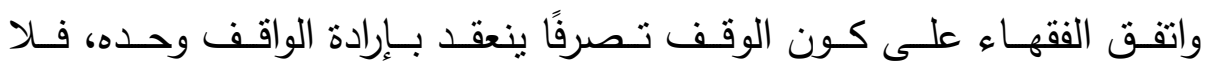

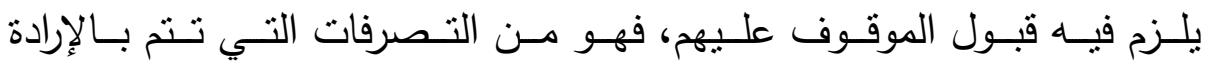

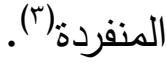

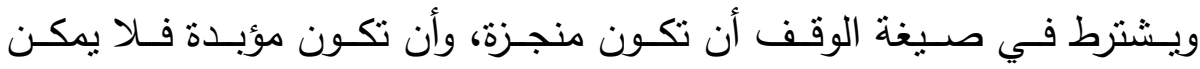

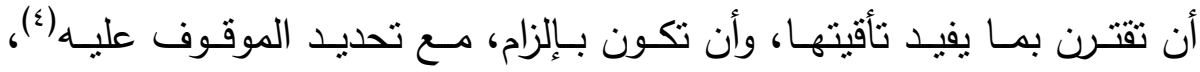
وعدم اقتران الصيغة بشرط يخل بمقصود الوقف بأنان.

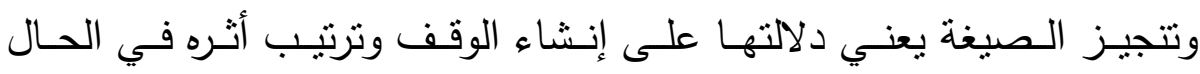

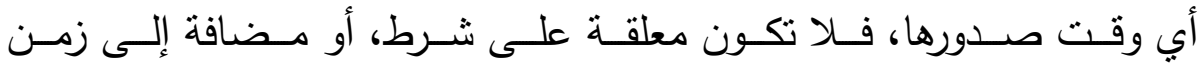
مستقبل، كقوله وققت قطعة الأرض هذه على على مسجد بلدتي (†).

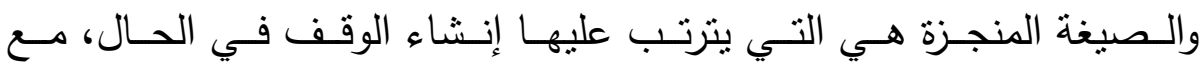

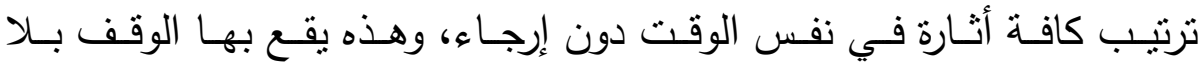

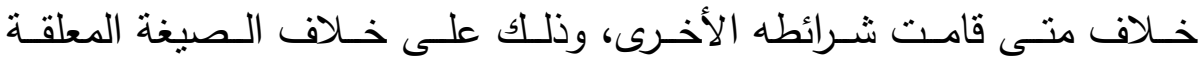

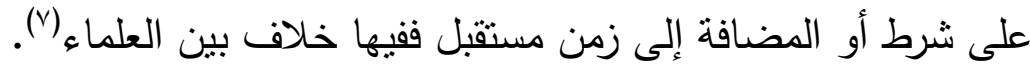

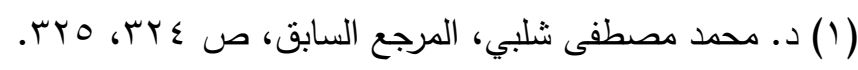

(Y) د. أحمد بن عبد العزيز الحداد، من فقه الوقف، دائرة الشئون الإسلامية والععل الخيري

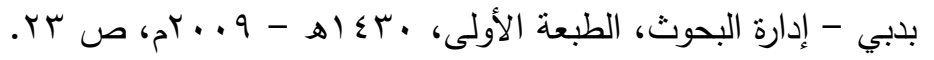

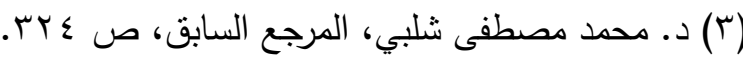
(ع) انظر : المرداوي، الإنصاف في معرفة الراجح من الخلاف، الجزء السابع، ص 1.

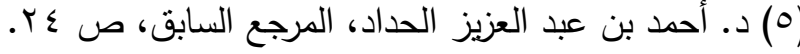

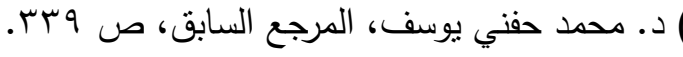

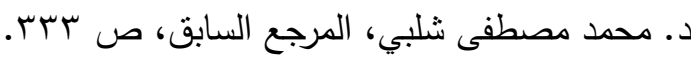


وعـن تأبيــد الـصيغة نجـــ أن جمهـور أهـل العلــم مـن الحنفيـة والـشافعية

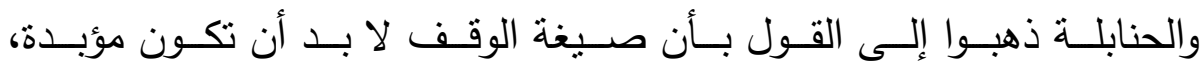

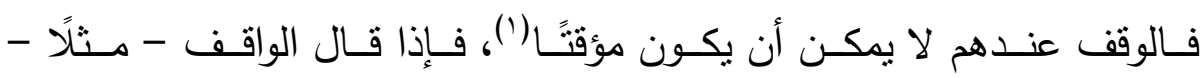

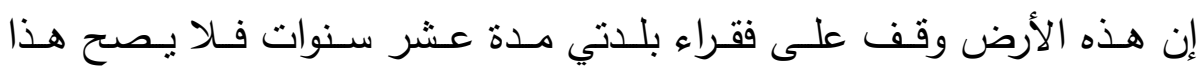

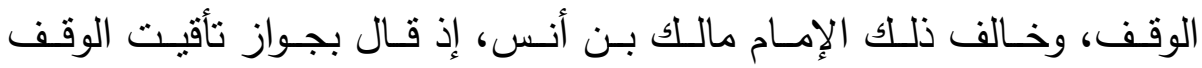

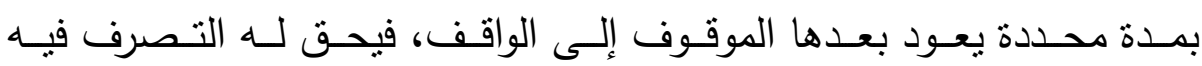
كيفما يشاء (r) ثانيًا - الواقف:

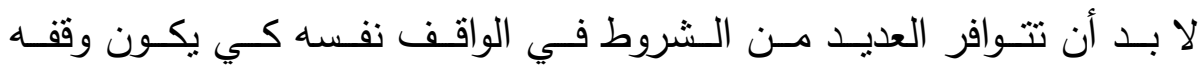

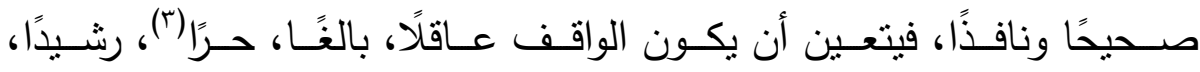

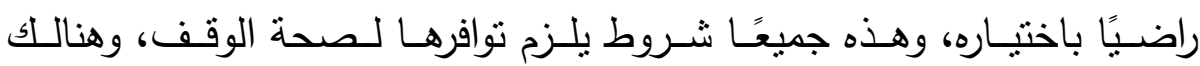

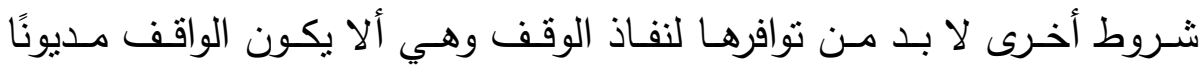

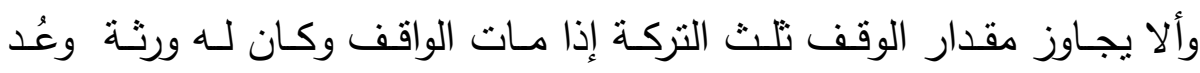

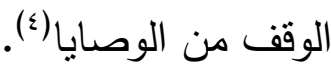

وعلـى ذلــك لا ينعقدـ الوقـف صـحيحًا إذا كـان الواقـف مجنونَـا أو معتوهًا،

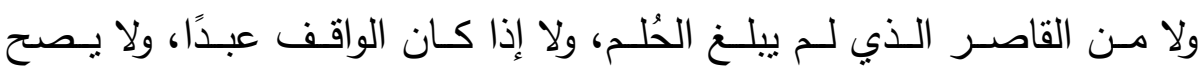

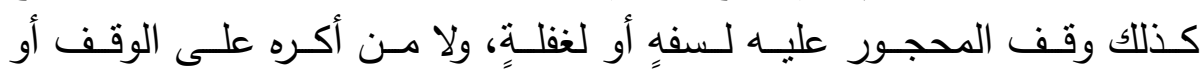

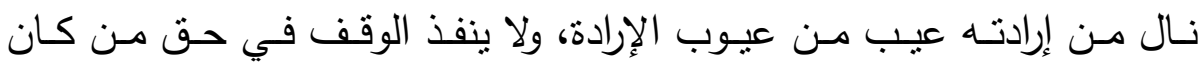

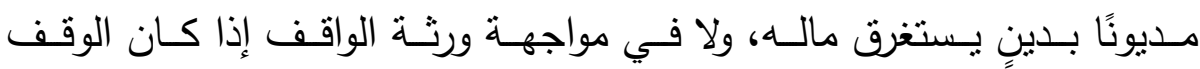

$$
\begin{aligned}
& \text { (1) د. محمد حفني يوسف، المرجع السابق، ص ب ؟ ب. }
\end{aligned}
$$

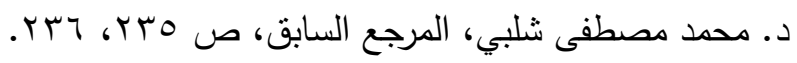

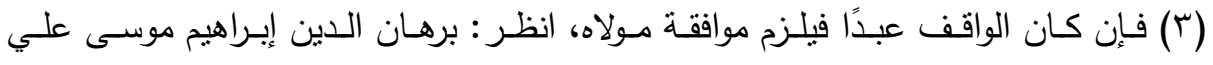

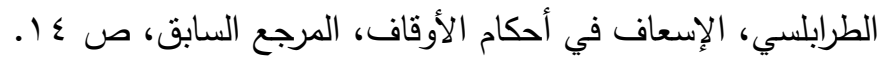

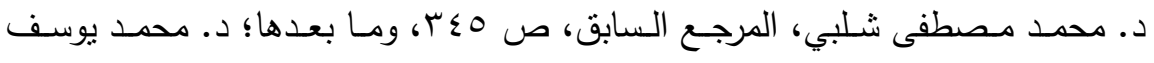

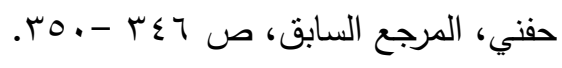


بمـا يزيد عن تلث التركـة إن كـان الوقف ينتج أثنره بعد الوفـاة، مـالم يوافق

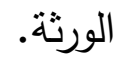

$$
\text { ثالثًا- الموقوف: }
$$

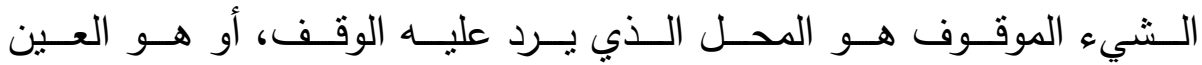

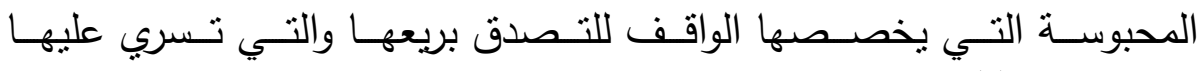

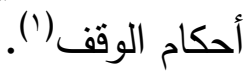

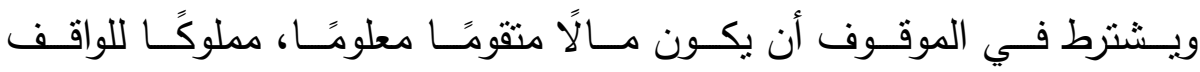
ملكية تامة مفرزة عند وقفه (؟).

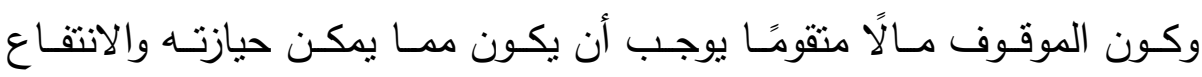

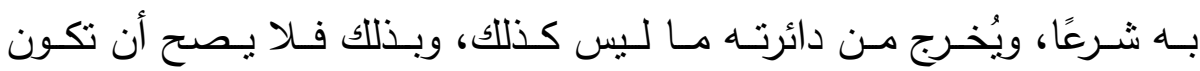

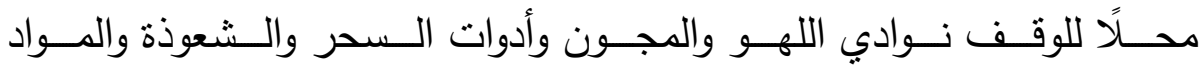
المخدرة أو مصانع إنتاج الخمور والمسكرات.

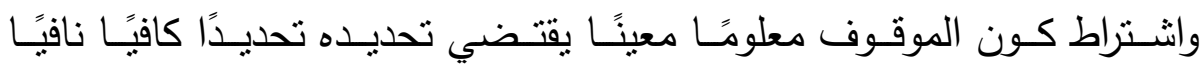

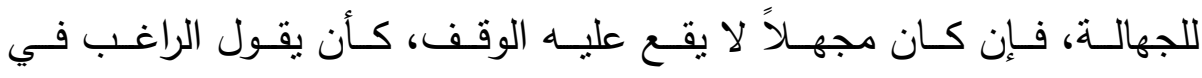

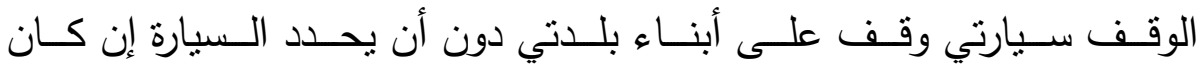
يمنالك العديد من السيارات.

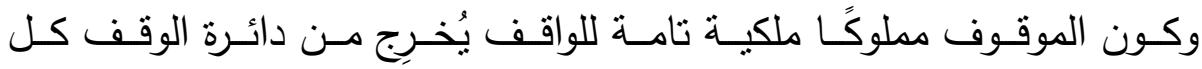

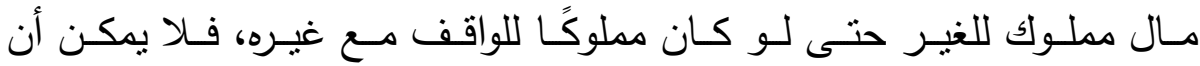
يقف المالك المشتاع قبل فرز نصيبه في المال وتحيده مفرزًا.

$$
\begin{aligned}
& \text { (1) د. محمد يوسف حفني، المرجع السابق، ص •ror. }
\end{aligned}
$$

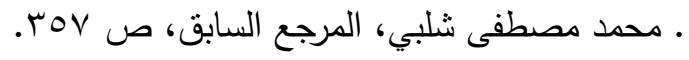


لابعًا - الموقوف عليه أو المستفيد:

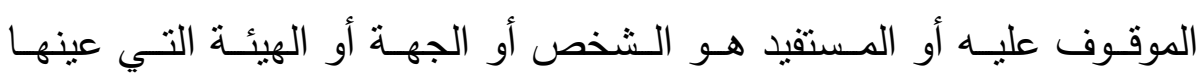
الواقف للاستفادة من ريع الموقوف ومنافعه.

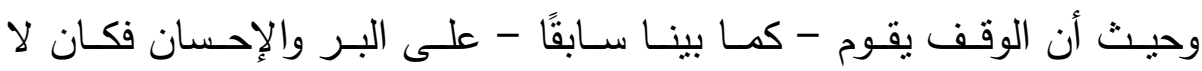

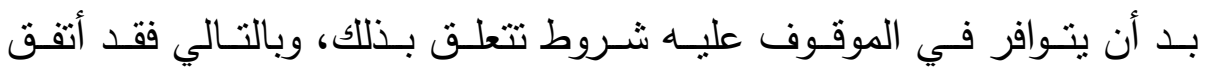

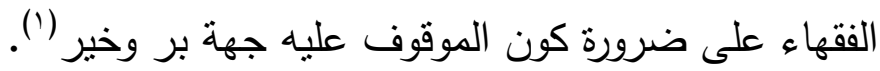

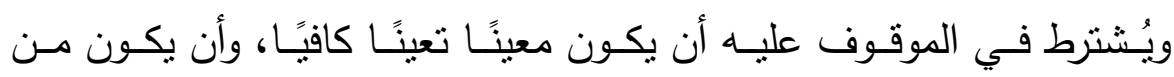

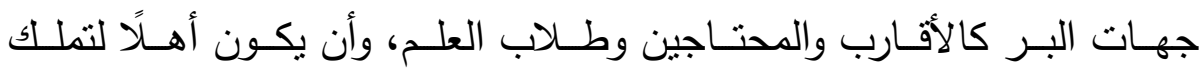

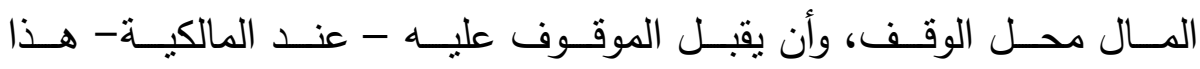

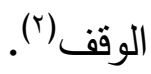




\section{المبحث الثاني}

\section{دور الرقف في نهضة المجتمع المسلم}

عبـر الوقف على مـر التـاريخ الإسـلامي المزدهـر عـن حالــة خاصـة فـي

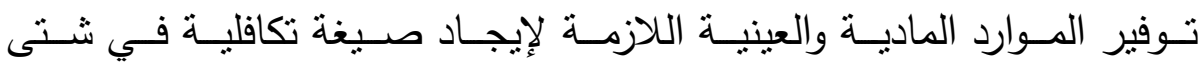

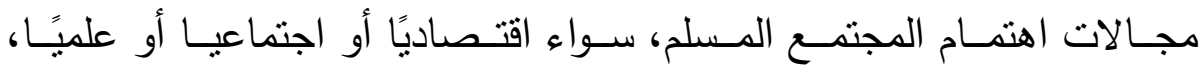

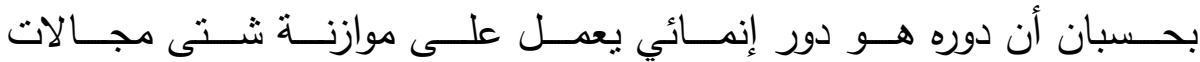

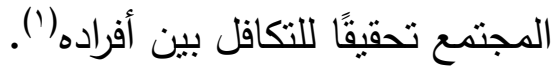
وحيـث إن المجـالات التـي يمكـن اسـتـعاء نظـام الوقـف الإســلامي

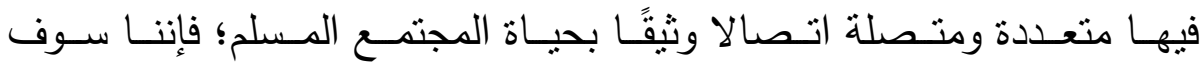

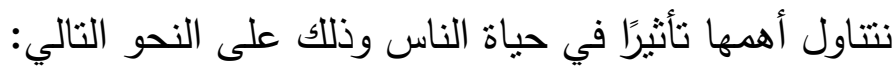
المطلب الأول: الوقف والتنمية الاقتصادية. المطلب الثاني: الوقف والنهضة التعليمية والثقافية. المطلب الثالث: الوقف والنهضة الاجتماعية. المطلب الرابع: دور الوقف في توفير الرعاية الصحية.

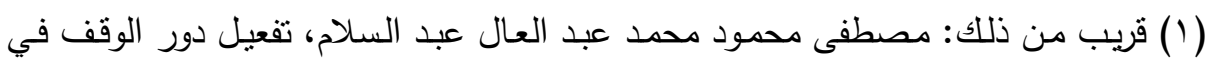

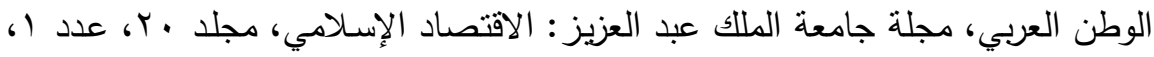

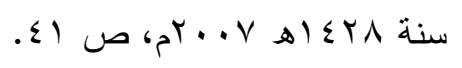




\section{المطلب الأول}

\section{الوقف والتنمية الاقتصادية}

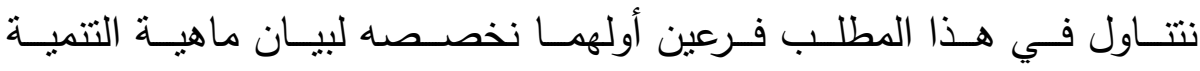

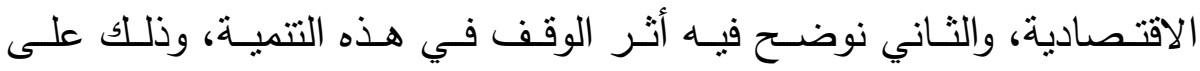

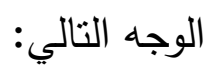

\section{الفرع الأول}

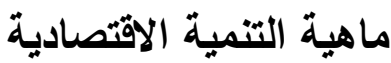

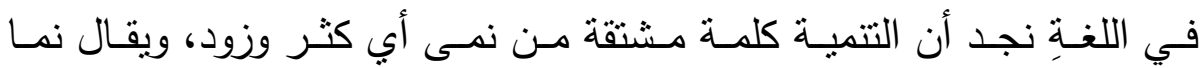

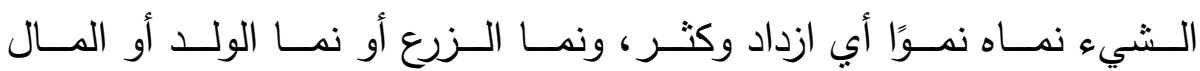
بمعنى الزيادة والكثرة، ونمى الثيء أني جعله ناميًا (').

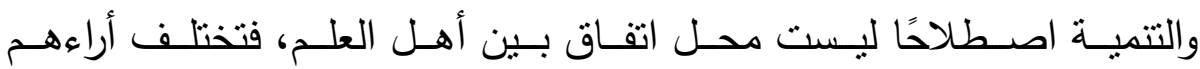

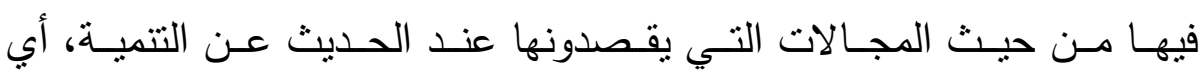

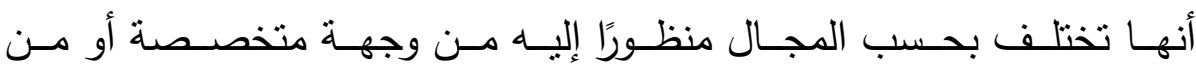

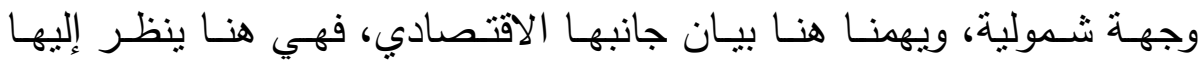

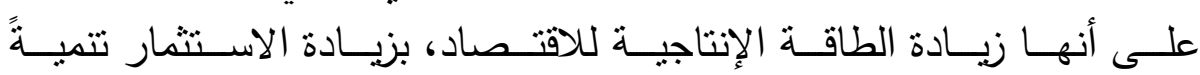
للإمكانات المادية والبشرية لإنتاج الدخل الحقيقي للمجتمع (؟).

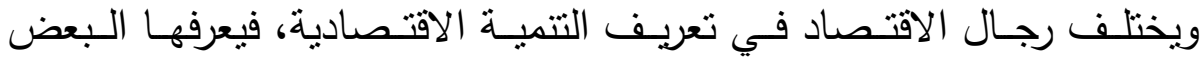

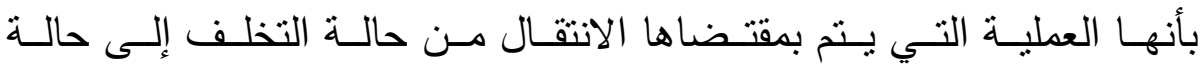

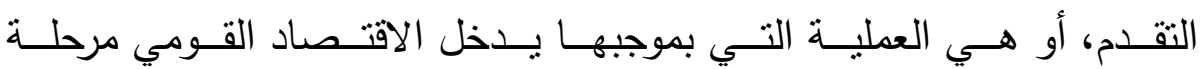

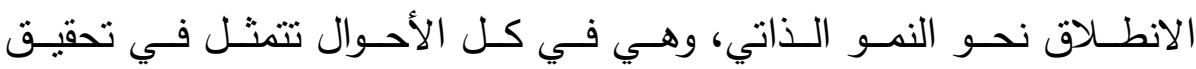

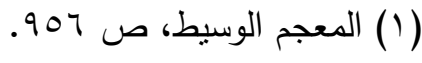

(ץ) د. محمد عبد العزيز عجيية، د. إيمان عطية ناصف، د. على على عبد الوهاب نجا، التتمية

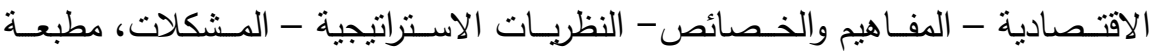

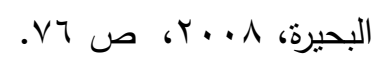




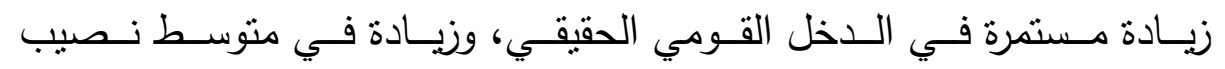

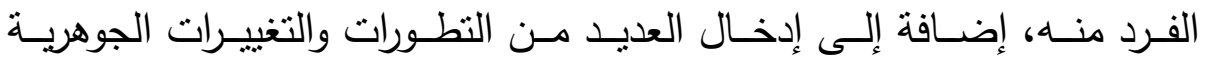

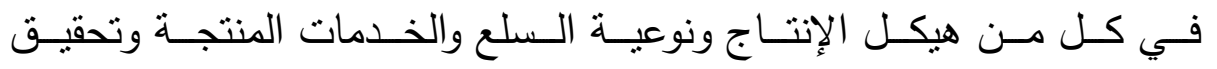
العدالة في توزيع الدخل القومي (').

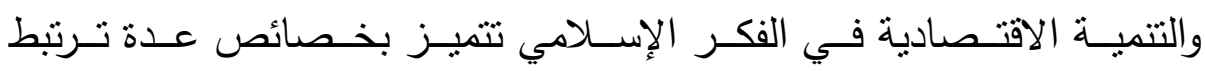

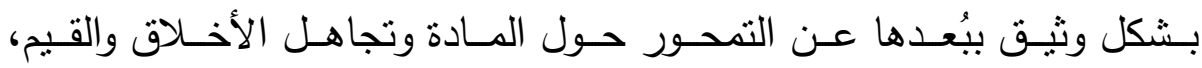

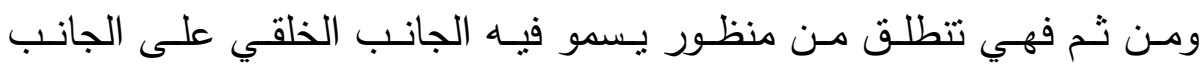

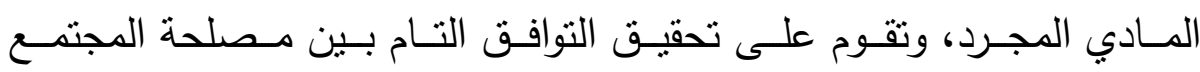

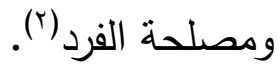

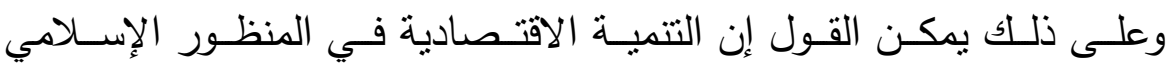

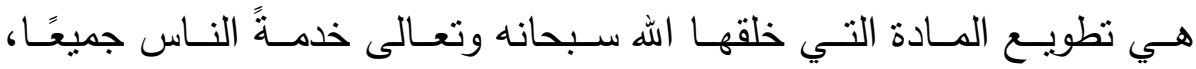

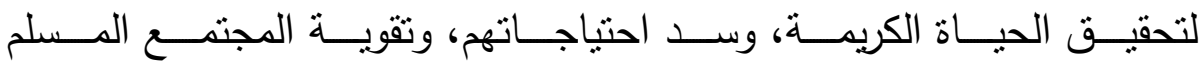
ونهضته.

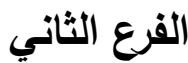

\section{أثر الوقف في التنمية الاقتصادية للمجتمع المسلم}

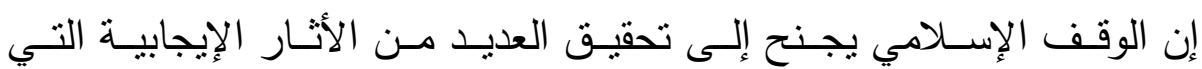

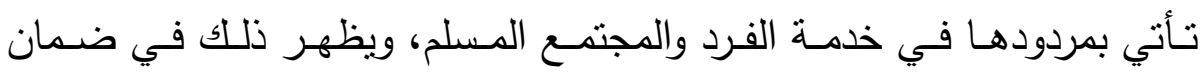

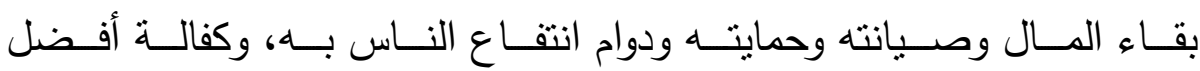

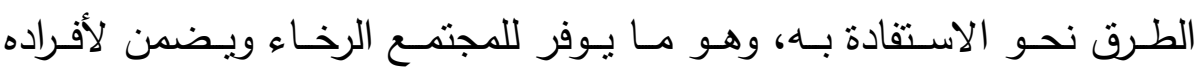

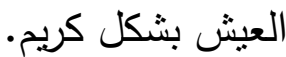

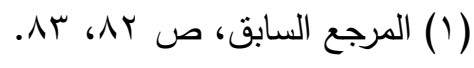

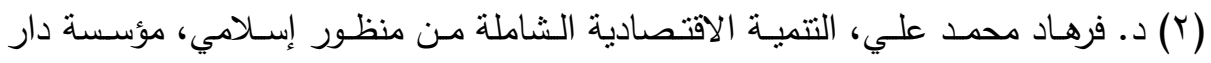

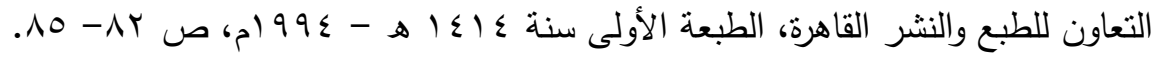




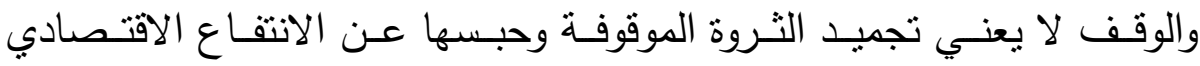

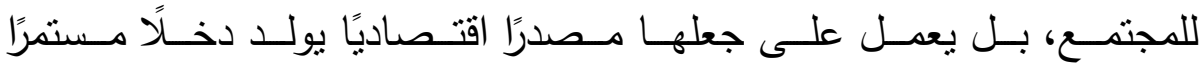
ومضطردًا يعمل على توفير حاجات المستقيدين منه حالاً واستقبالاً (1).

ويـنهض الوقـف بالناحيـة الاقتــصادية للمجتــع مـن خـلال العديــــــن مـن

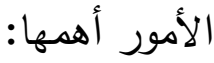
- - - دعم وتثجيع نمو العملية الإنتاجية وزيادة الاخل:

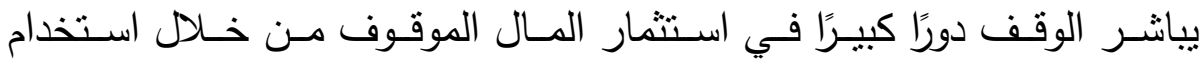

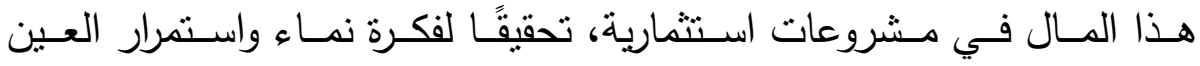

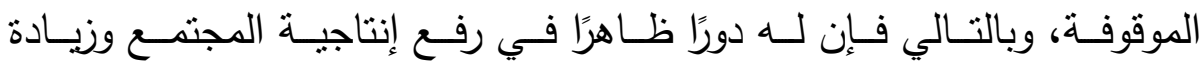

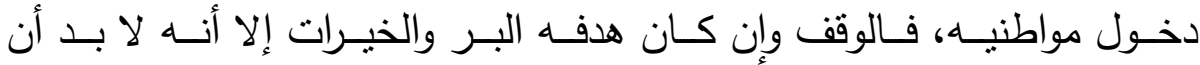

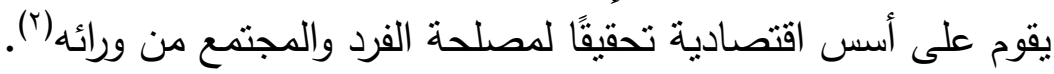

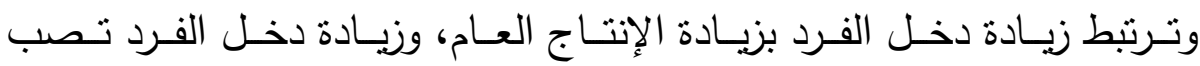

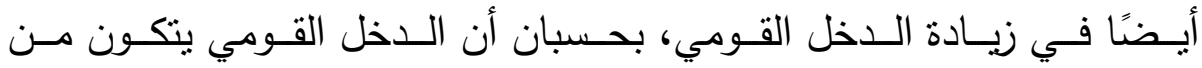
مجموع دخول أفراد المجتمع. ولا شـك أن زيـادة الإنتاج - ومـن ثم زيـادة الـدخل الفـردي والقومي - يـرنبط

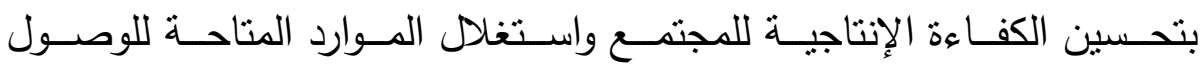

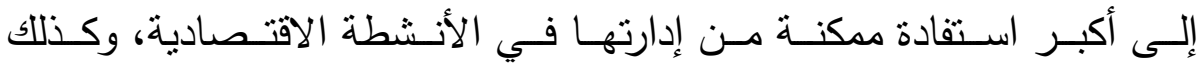

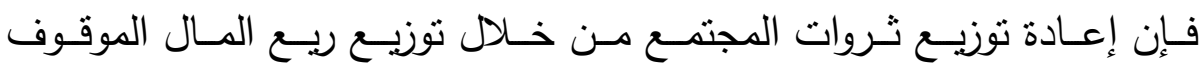

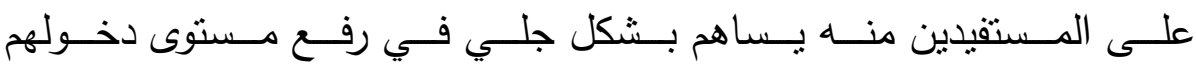

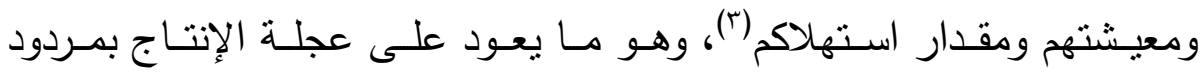

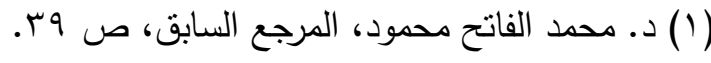

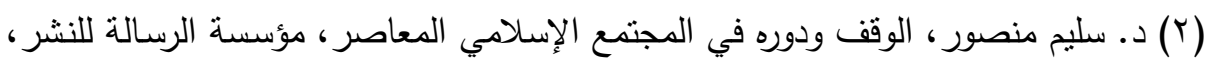

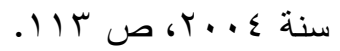

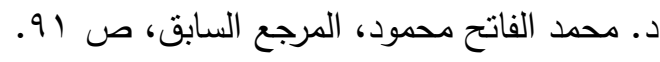


إيجابي يتمثل في زيـادة الإنتاج لتوفير السلع والخدمات لهم ولغيرهم وهـو ما يسهم بشكل ظاهر في حركة اقتصادية مضطردة.

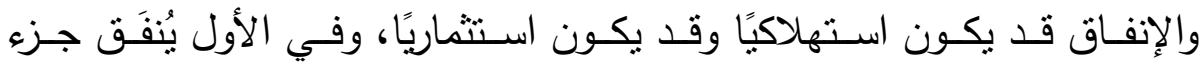

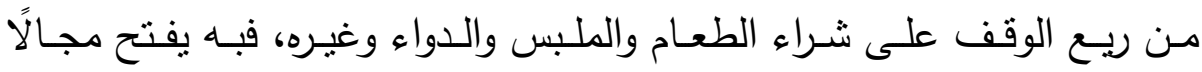

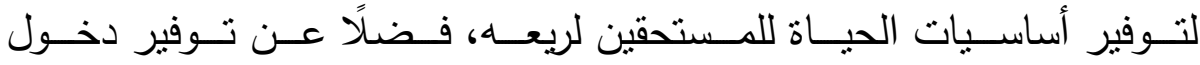

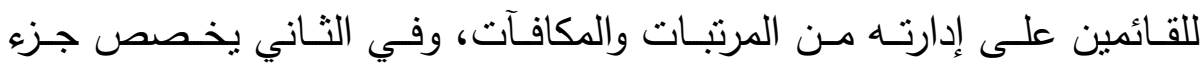

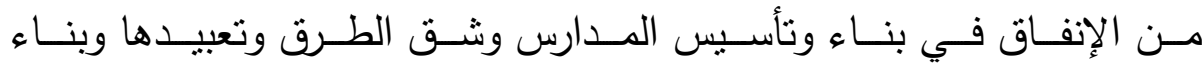

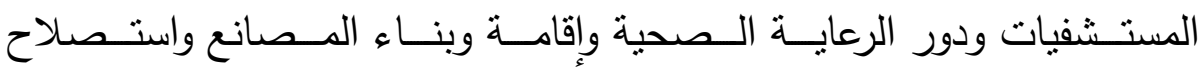

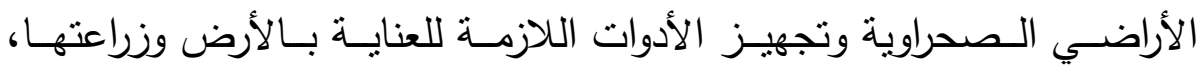

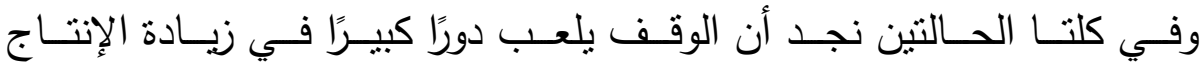
وبالتالي زيادة دخول الأفراد.

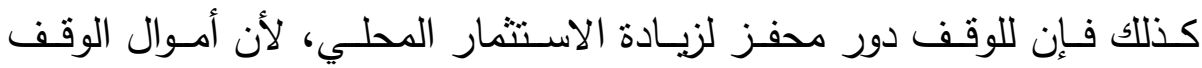

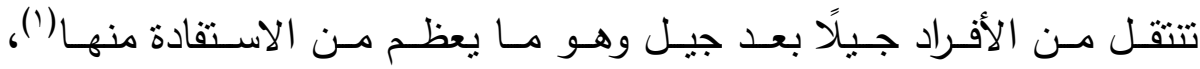

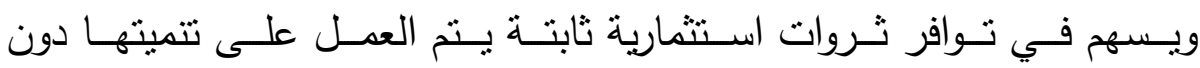

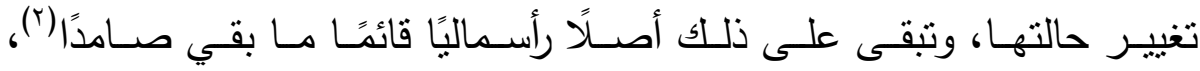

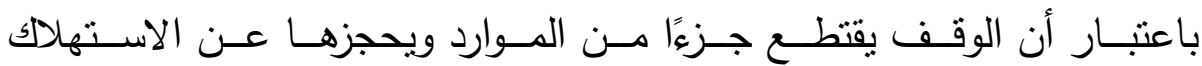

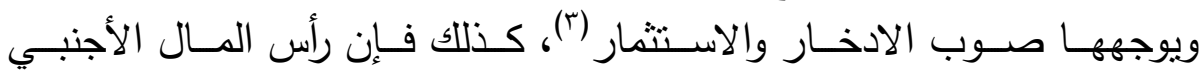

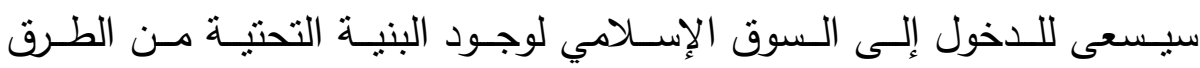

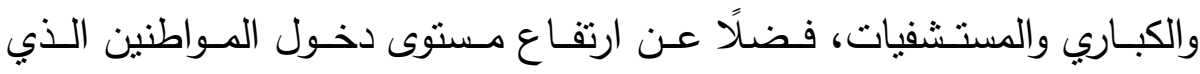

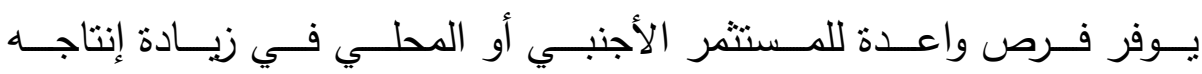

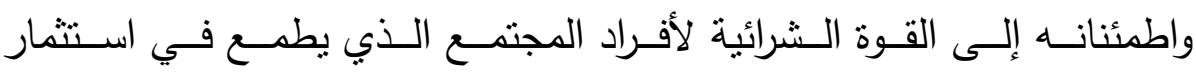

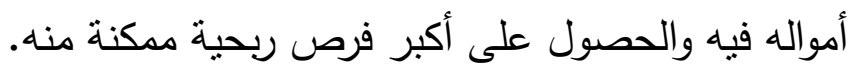

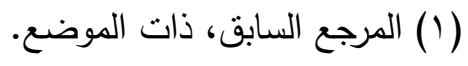

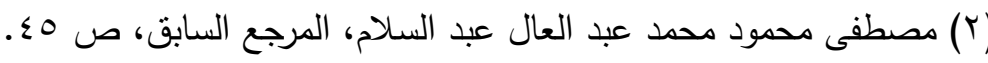

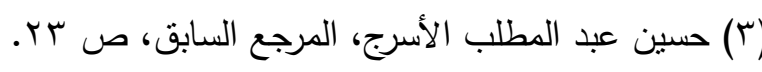




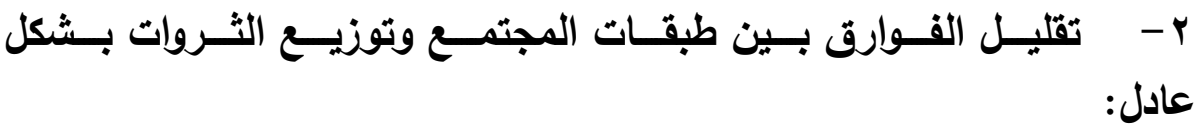

الفـرد في المجتـع المسلم هـو حجـر الزاويـة، ويُنظـر إليـهـ على أنسه ثـروة

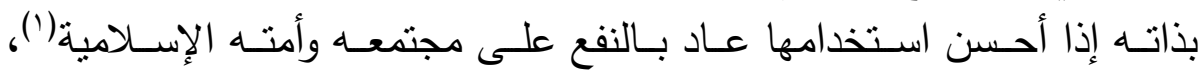

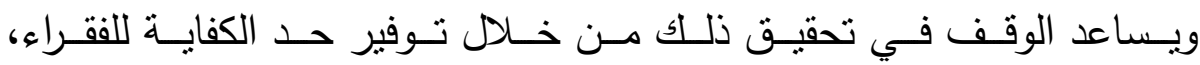

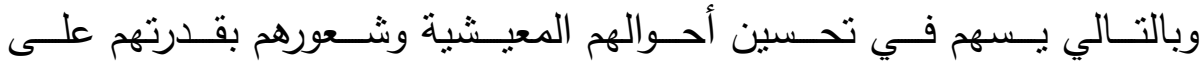

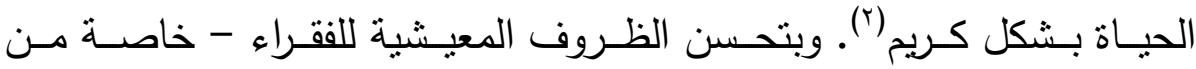

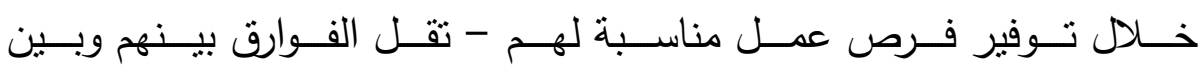

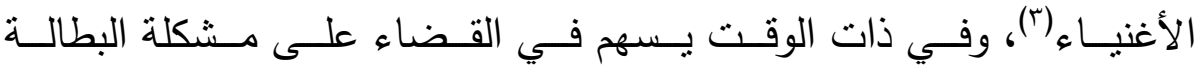
بحسبانها مشكلة كبرى تؤرق المجتمعات المسلمة وغيرها.

وكذللك يساهم الوقف بـورة كبيـرة في منـع ظـاهرة تركـز ثـروات المجتهـع

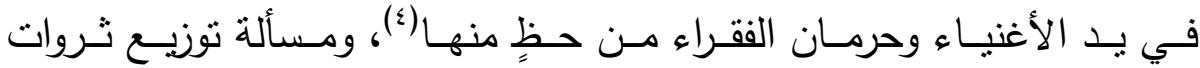

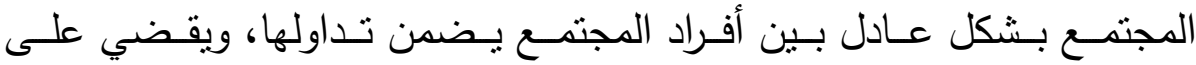

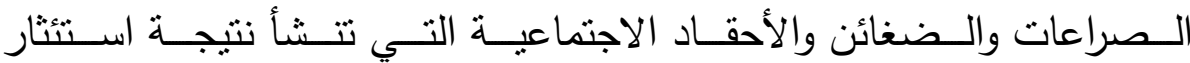

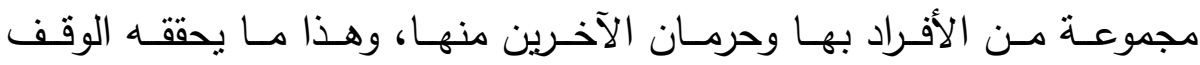

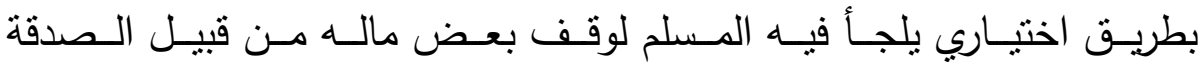

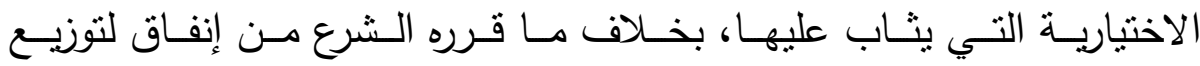

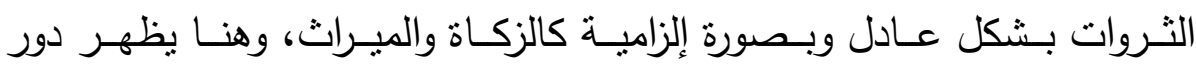

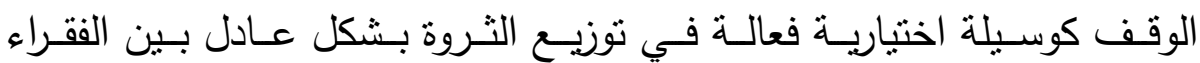
والأغنياء.

(1) د. عبد الهادي النجار ، الإسلام والاقتصاد، عالم المعرفة، المجلس الأعلى للثقافة والفنون

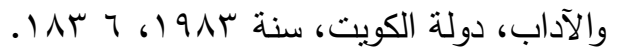

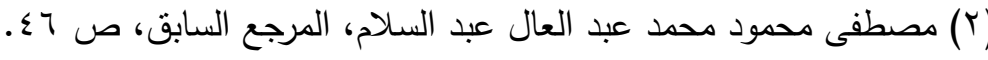

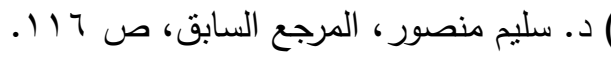

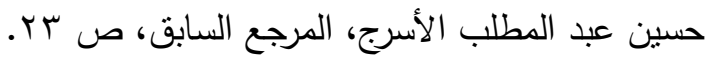


r-دور الوقف في تثجيع حركة التجارة الداخلية والدولية:

لقد كـان للوقف الإسـلامي أثنرًا ملموسًا في ازدهـار واضطراد حركـة التجـارة

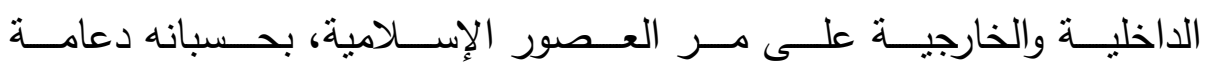

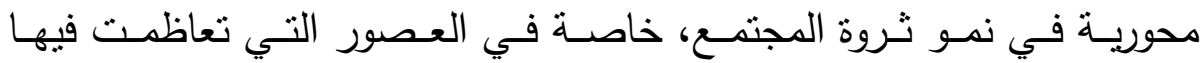

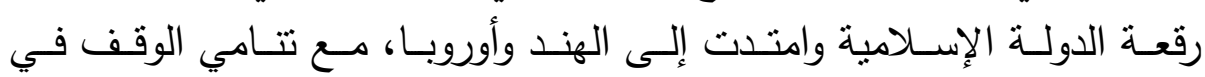
هذه العصور (')

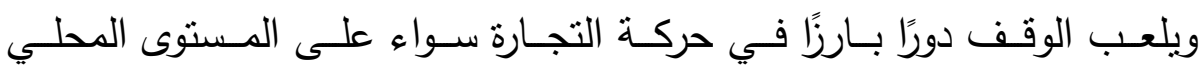

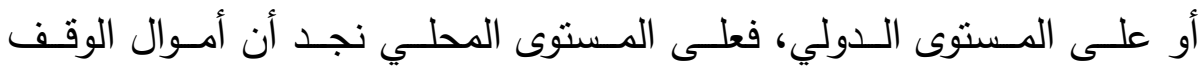

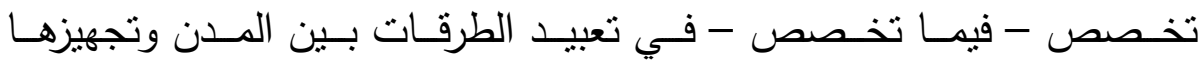

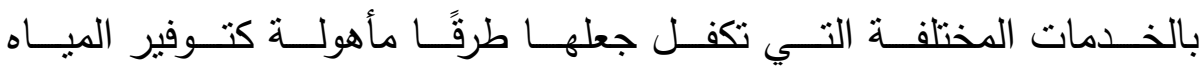

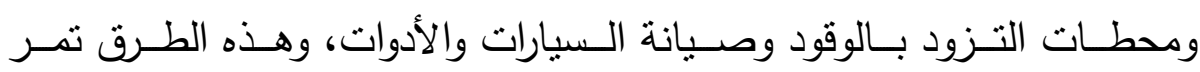

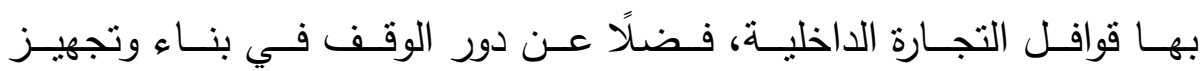

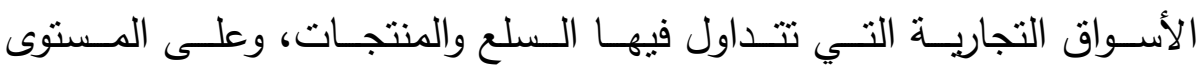

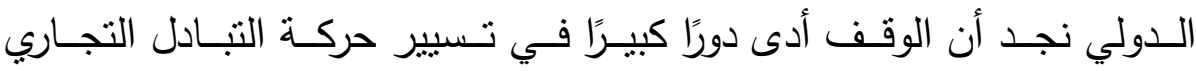

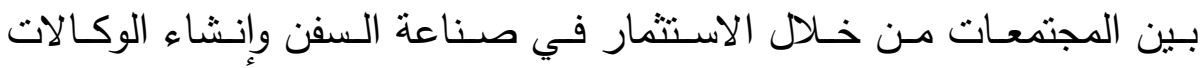
التجارية وتداول السلع بين الأقطار المختلفة (r).

المطلب الثاني

\section{الوقف والنهضة التعليمية وإلثقافية}

العلم هـو عمـاد نهضة الأمـم وأسـاس ازدهارهـا وتقدمها، وهـو سبيلها نحـو

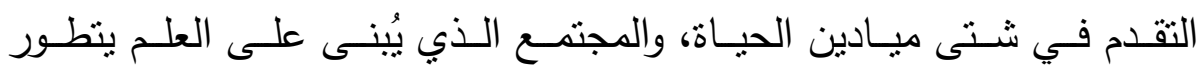

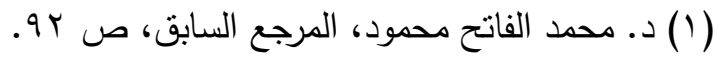

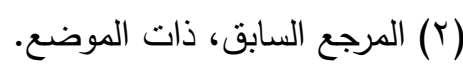




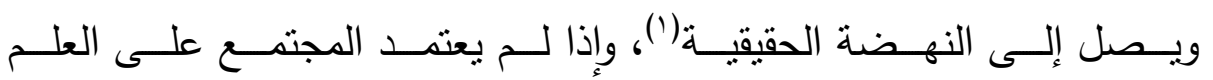

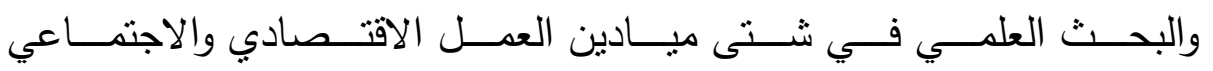
والصحي والهندسي والتقني لن يجني شينًا وسيهدر جهوده بلا طائل (؟).

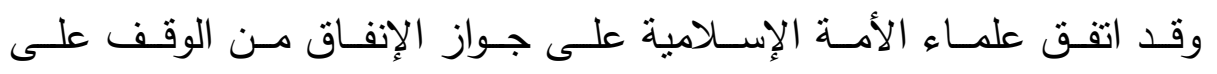

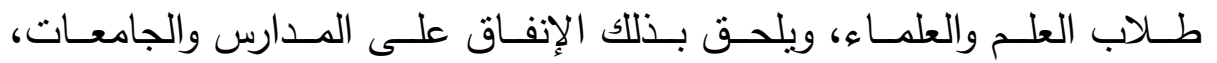

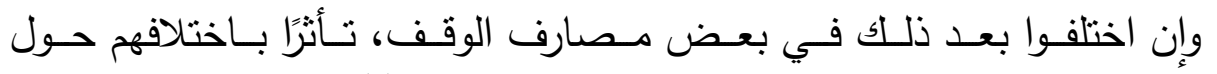

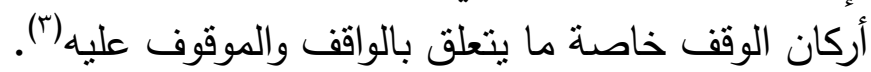

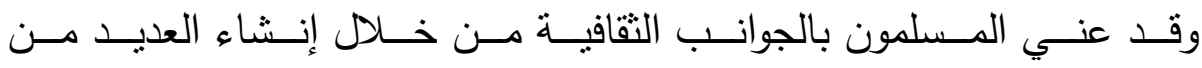

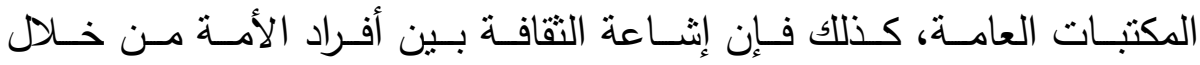

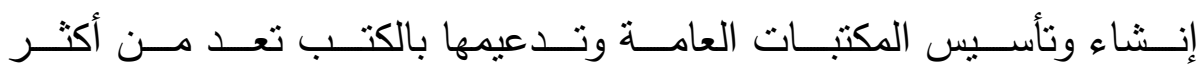

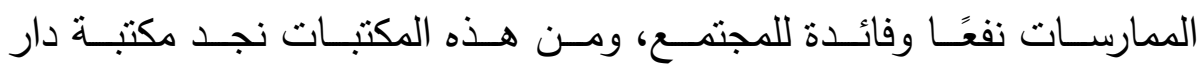

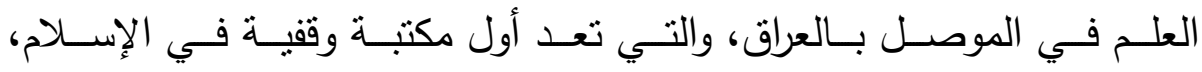

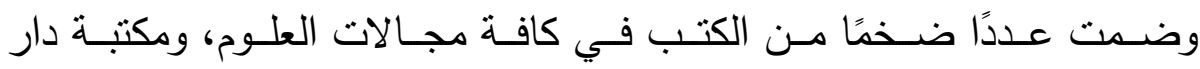

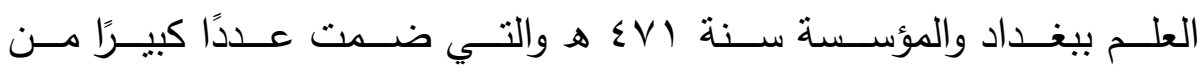
الكتب، ومكتبة القرويين التي ضمت العونة العديد من المخطوطات النادرة(أ).

(1) د. دلالـي الجيلالـي، دور الوقف في النهضة العلميـة والنقافيـة- قـراءة في التجربتين الإسلامية والغربية، مجلة الأكاديمية للاراسات الاجتماعية والإنسانية، قسم العلوم القانونية

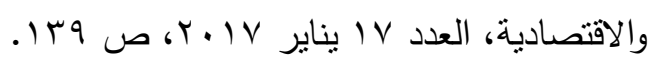

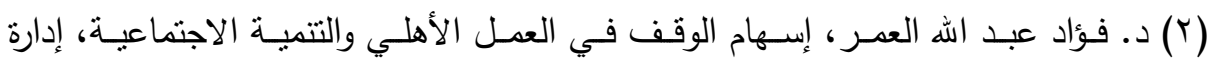

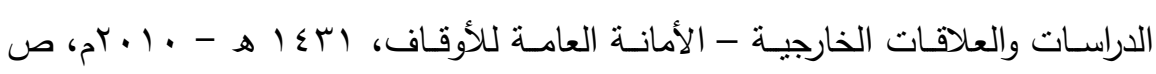

(r) وفي تفاصيل هذا الخلاف والحالات التي أجاز فيها الفقهاء الإنفاق من مال الوقف على

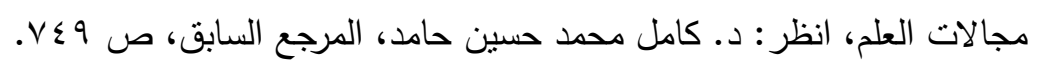

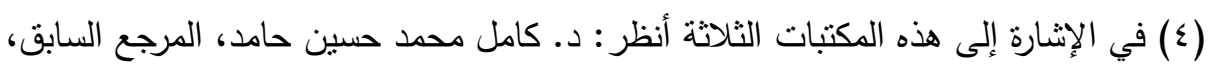




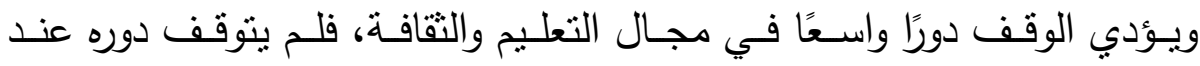

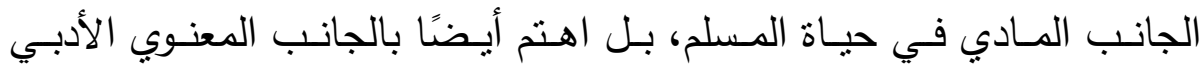

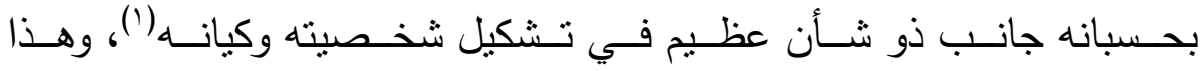

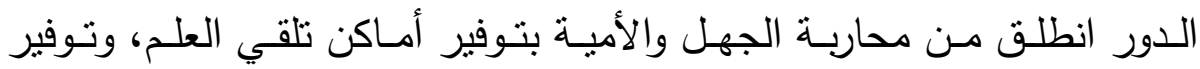

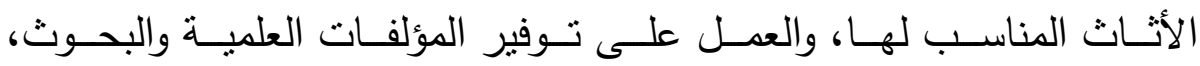

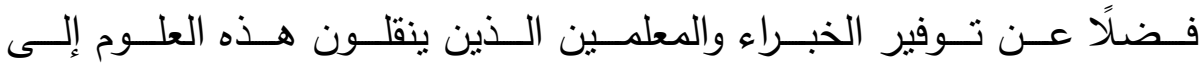

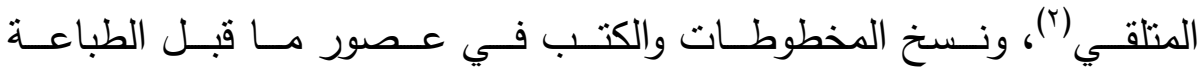

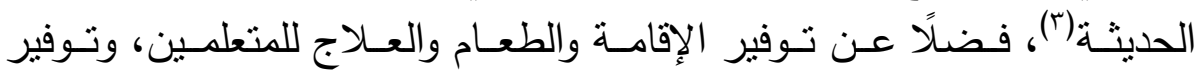

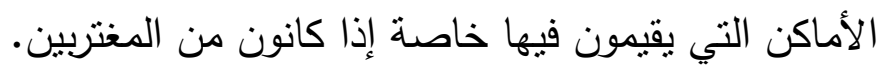

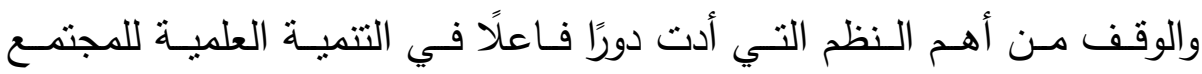

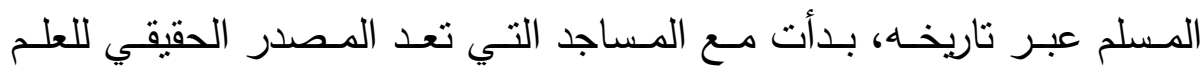

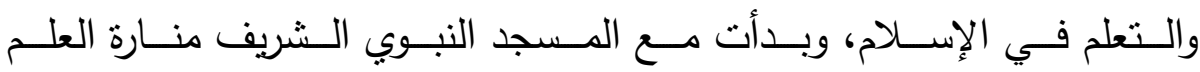

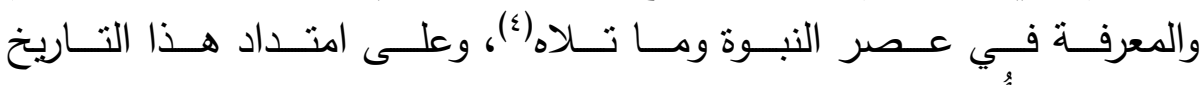

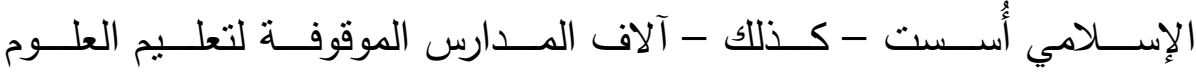

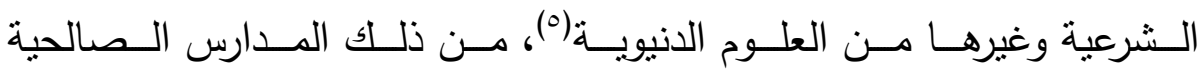

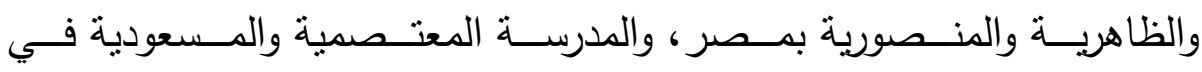

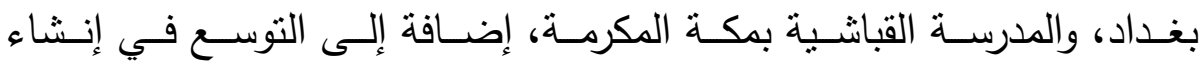

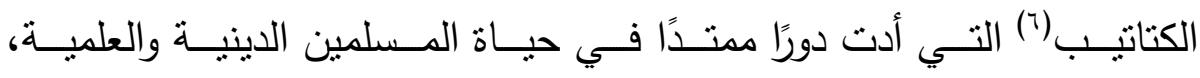

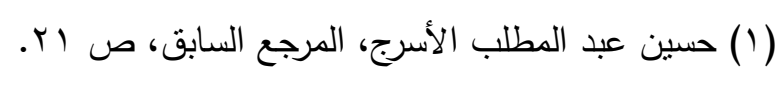

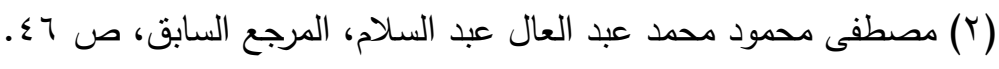

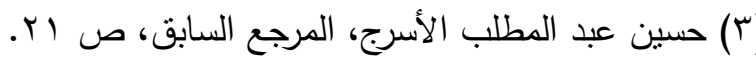

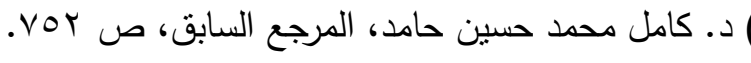

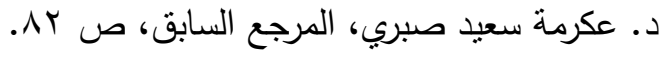

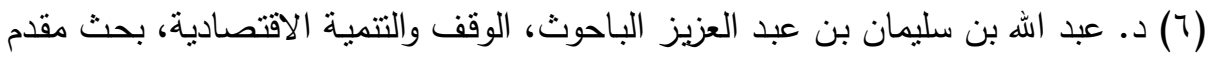

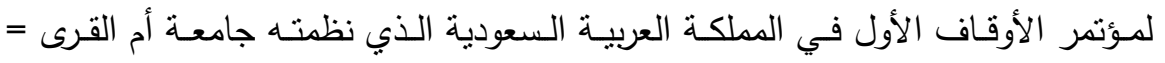


وفي مـصر لـدينا أنسشئت جامعـة الأزهـر ، وجـامع عمـر بـن العـاص وتـم تمويلهما من أموال الأوقاف (').

ولا يقف الوقف في المجـال التعليمسي والثقافي عند علم معين، بـل تنوعت

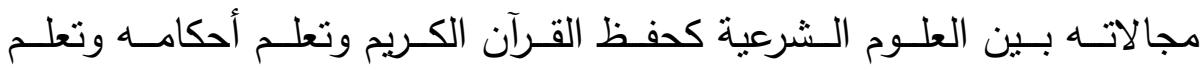

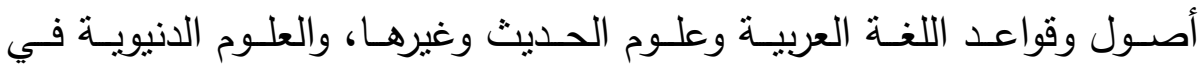
شتى مجالات الحياة الاقتصادية والطبية والهندسية وغيرها.

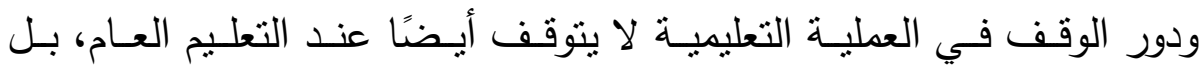

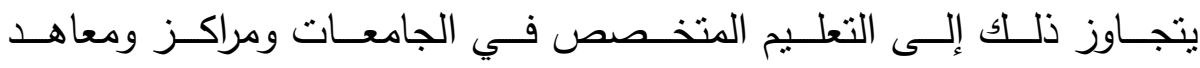

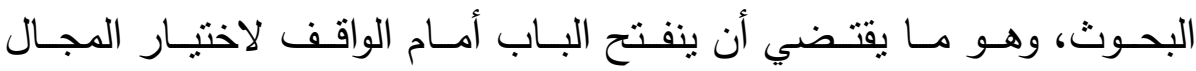

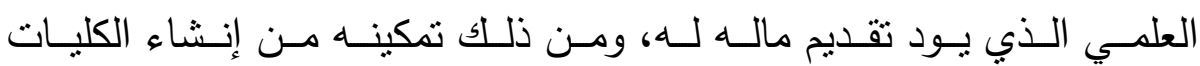

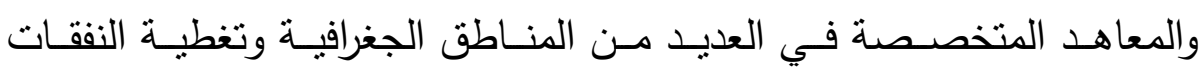

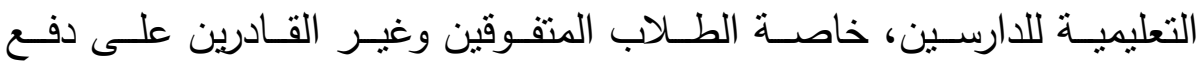

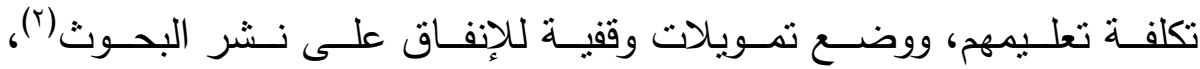

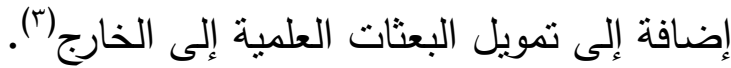

وفي مجـال البحـث العلمسي معـروف أن البحـث العلمي مكلف ماديًا بدرجـة

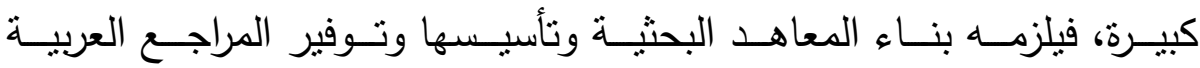

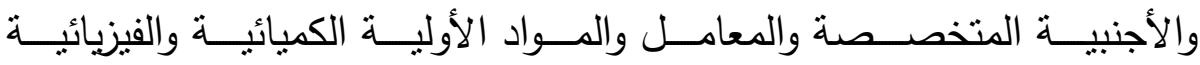
ونحوهـا، فضضلً عـن تـوفير نفقـات ضـخهة لـسفر البـاحثين للاسـتزادة مـن

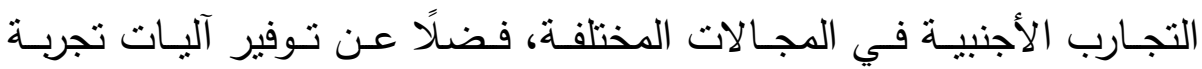

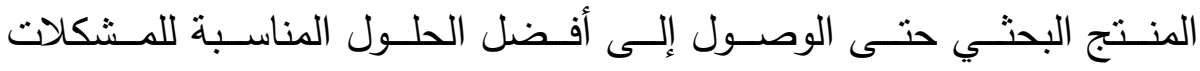

$=$

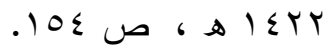

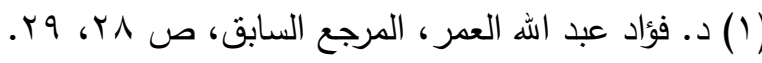

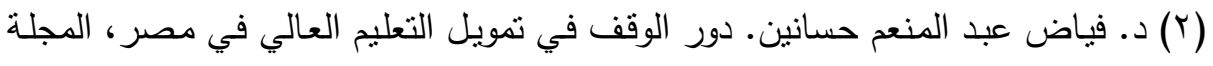

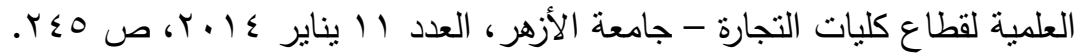

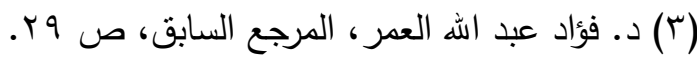




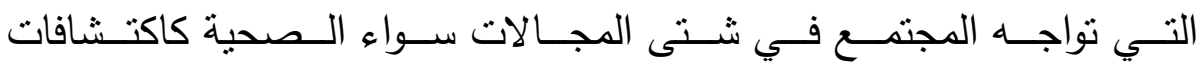

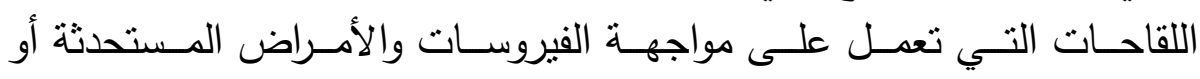

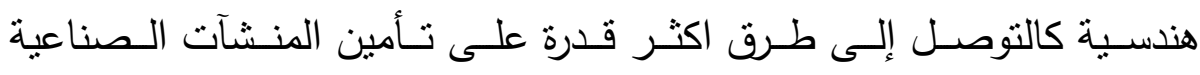
كالمنشآت النووية وغيرها.

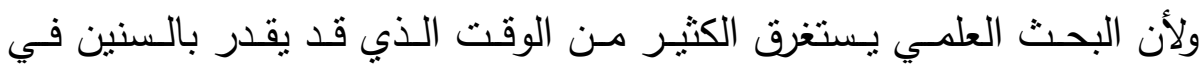

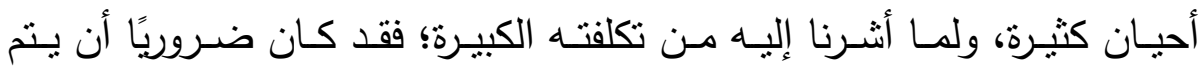

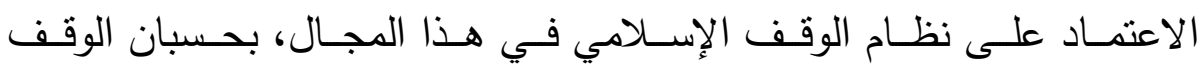
يمثل مصدر دائم ومستمر للتمويل ('). ولهـذه المنــافع المتعـددة والتـي تعـود علـى المجتمـع المسسلم فـي المجــال

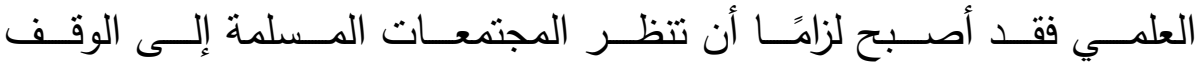

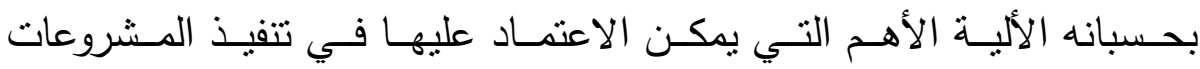

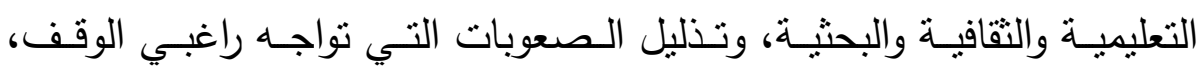

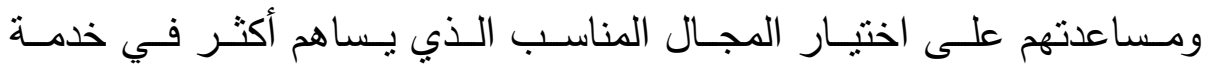

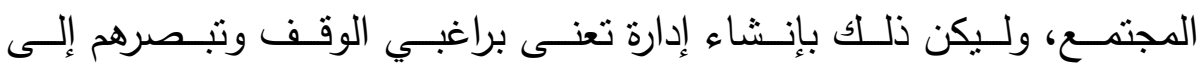

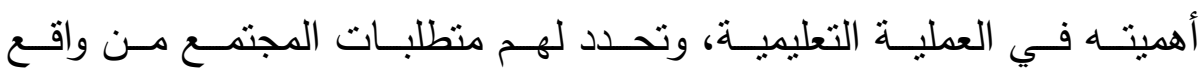

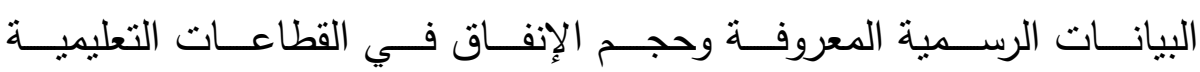

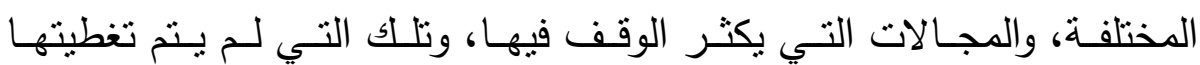
من المواطنين بعد. 


\section{المطاب الثالث}

\section{الوقف والنهضة الاجتماعية}

إن غايـة الإســام هـي الارتقاء بالإنسان في الـنبا والآخـرة، ومـن هنـا كـان

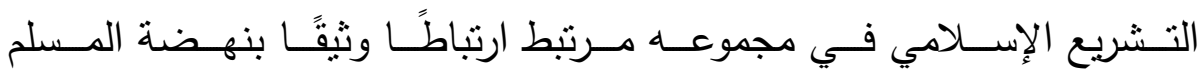

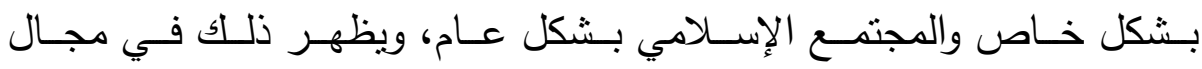

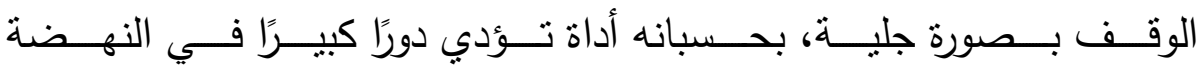

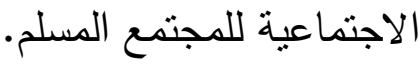

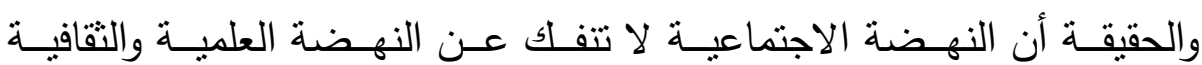

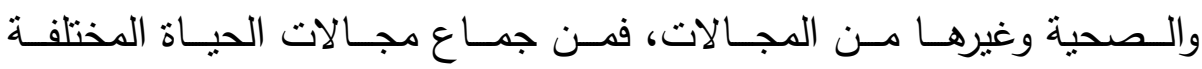

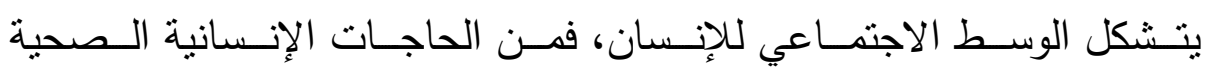

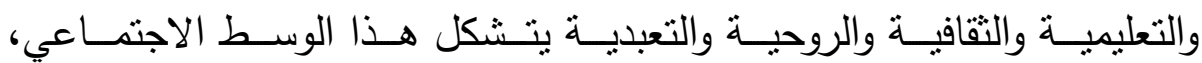

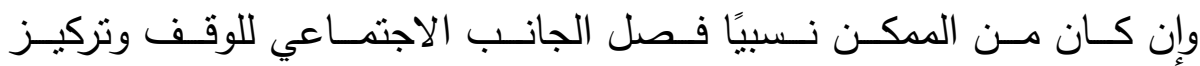

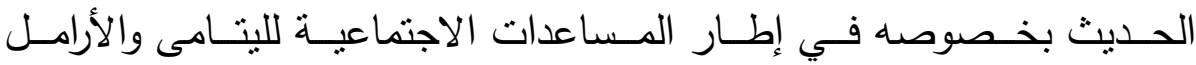

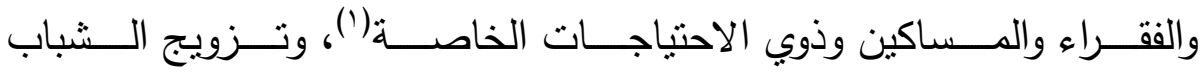

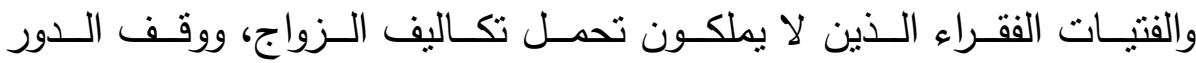
الخاصة لإقامة أعراسهم ودور إيواء المسنين والعجزة(†)، وما إلى ذلك. للك.

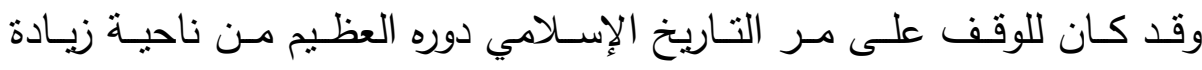

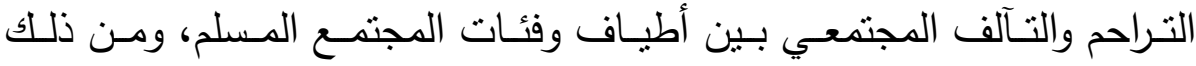

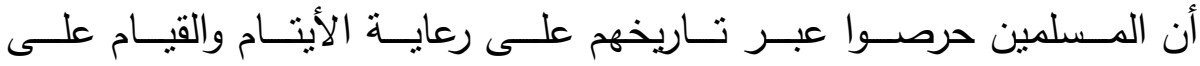

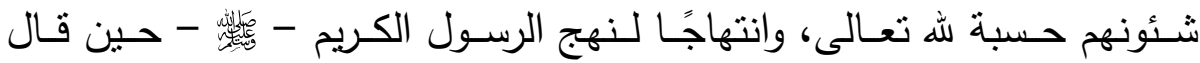

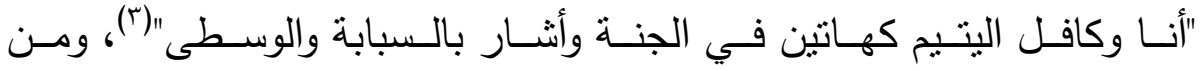

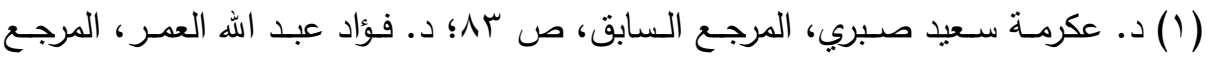

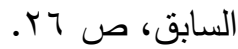

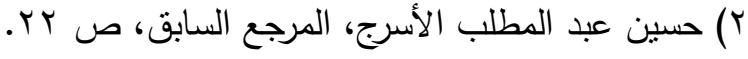

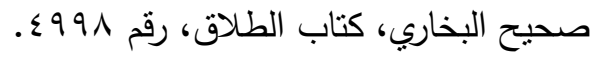


صـور رعايـة الأيتام إنشاء مكاتب تعليم الأيتام ورعايـة شـئونهم مـن مأكل

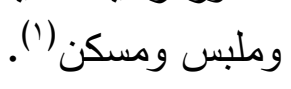

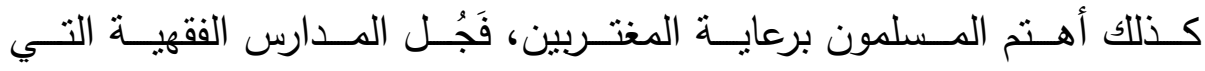

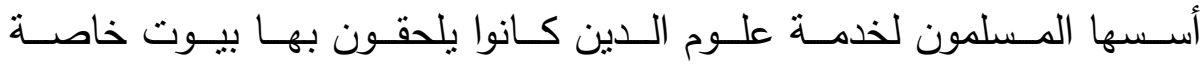

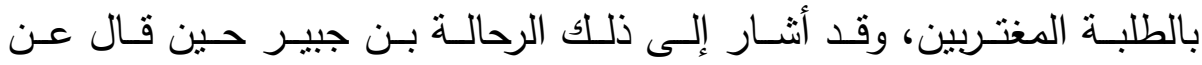

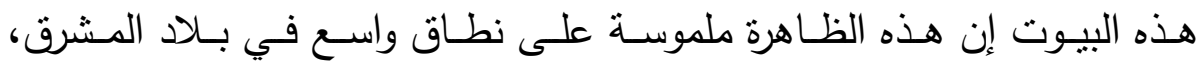

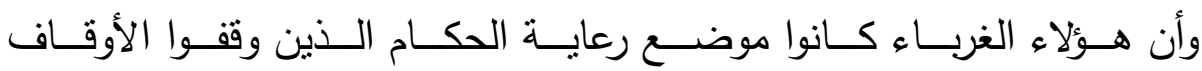

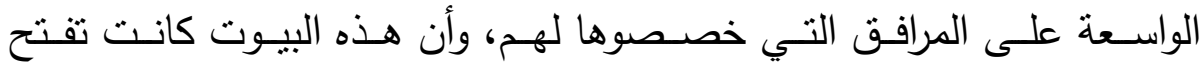

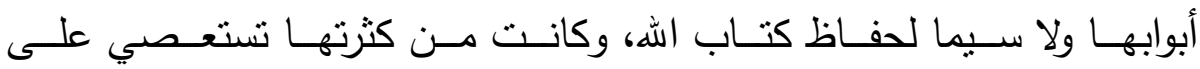

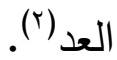

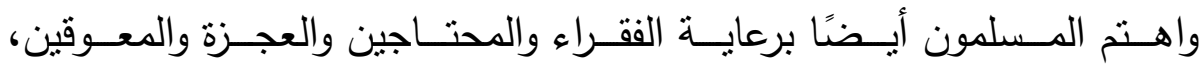

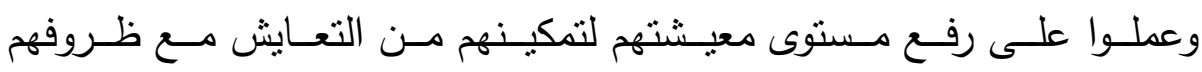

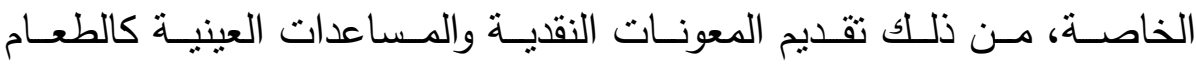

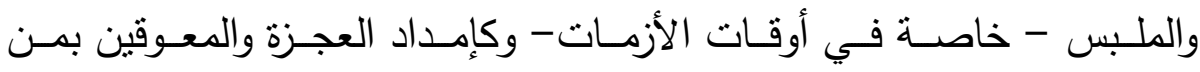

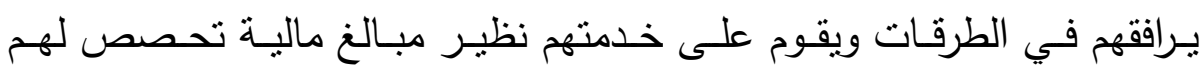
كرواتب تصرف من ريع الأوقاف ().

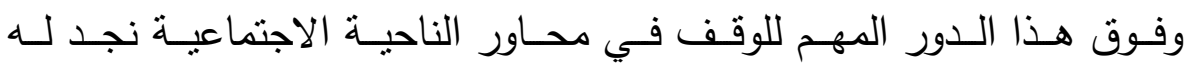

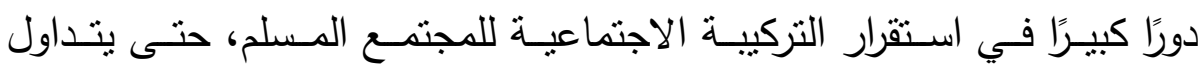

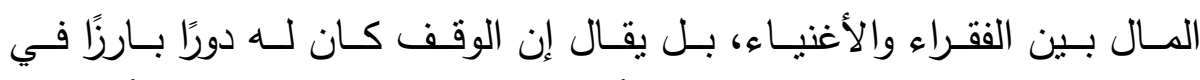

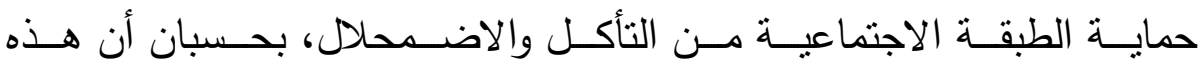
الطبقة تساعد على استقرار المجتمع وتساعد على تتميته اقتصاديًا (ई).

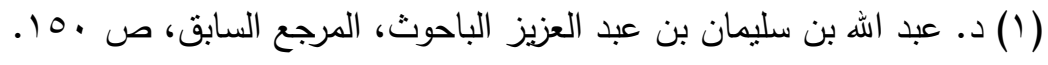

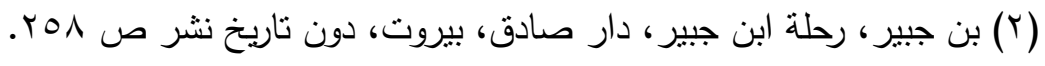

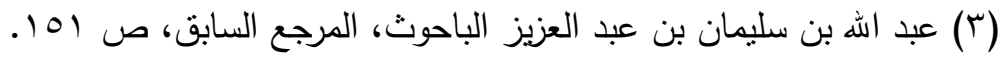

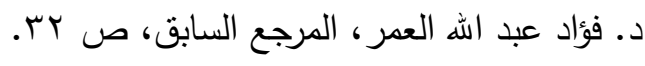




\section{الإطلب الرابع}

\section{دور الوقف في توفير الرعاية الصحية}

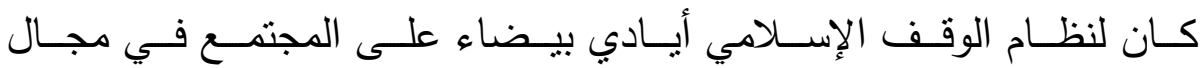

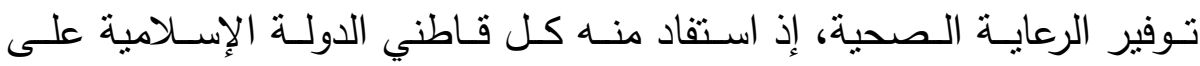
اختلاف مشاربهم وأصولهم وعقائدهم.

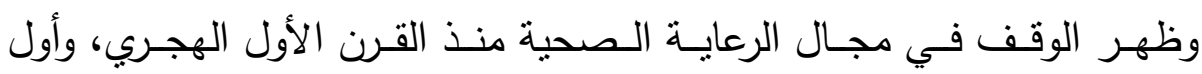

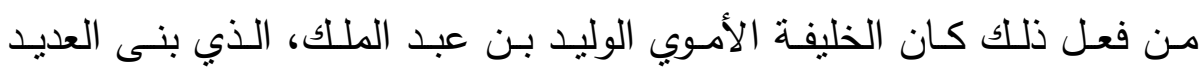

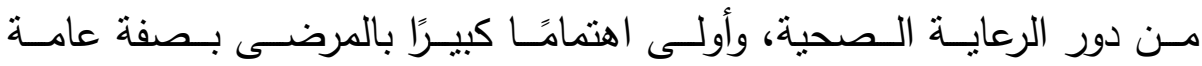

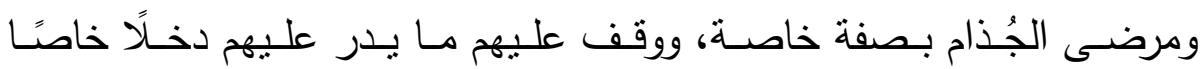

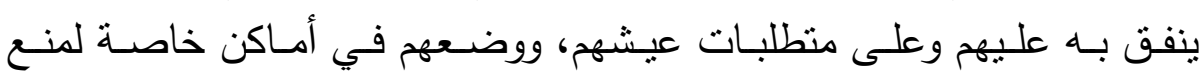
خروجهم ونشرهم العدوى بين غيرهم (').

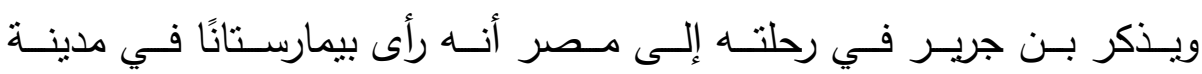

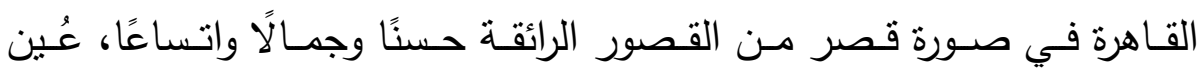

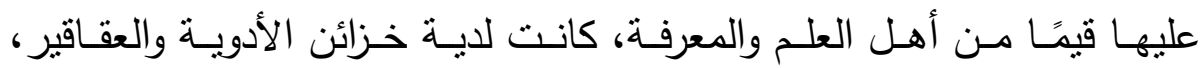

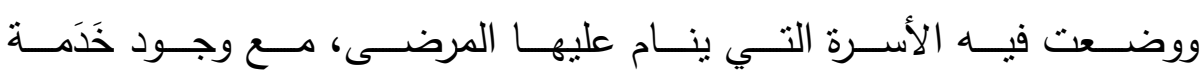

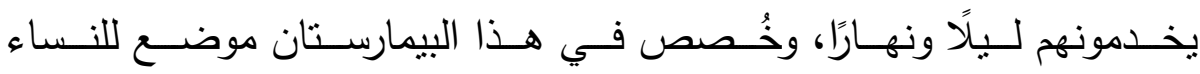

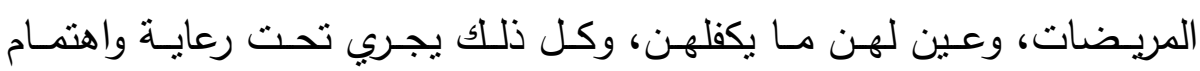

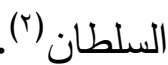

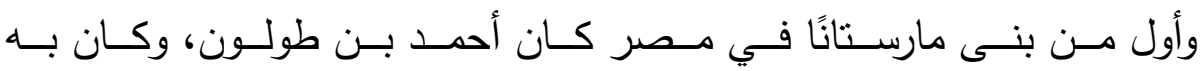

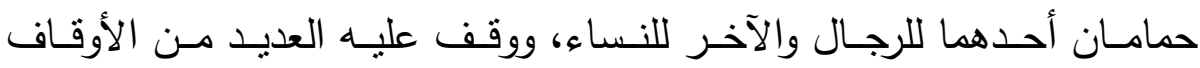

( (1) محمد بن محمد بن عبد الكريم بن عبد الواحد الثيباني (ابن الأثير)، الكامل في التاريخ،

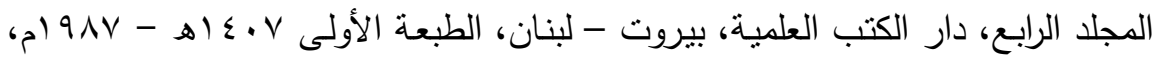

$$
\text { ص ص T Y وما بعدها. }
$$

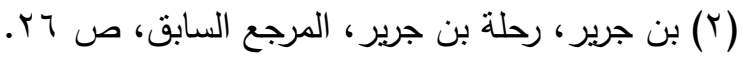

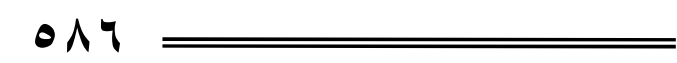




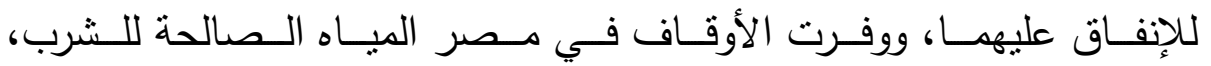

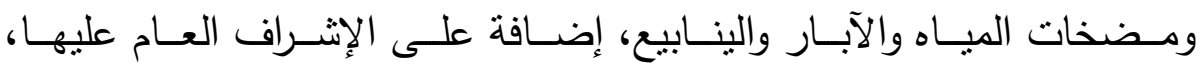

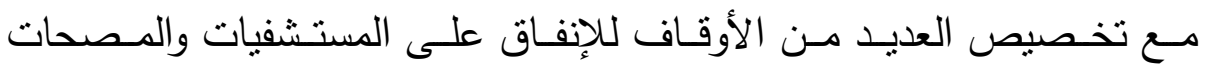

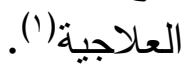

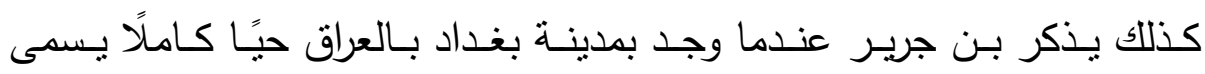

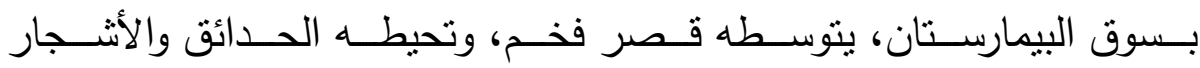

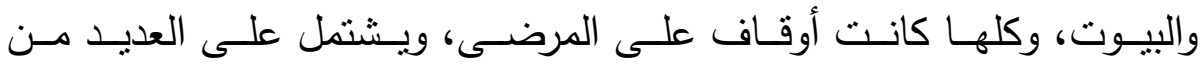

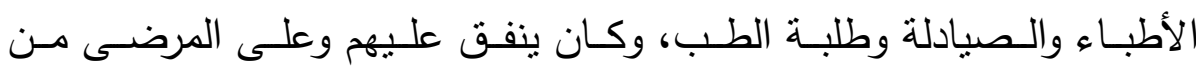
أموال الوقف المنتشرة ببغداد (؟).

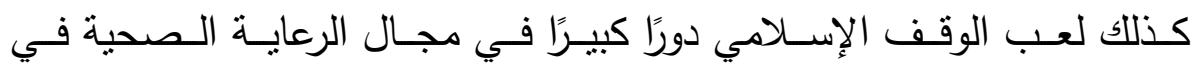

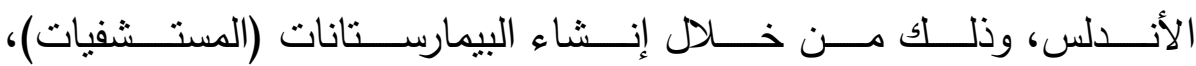

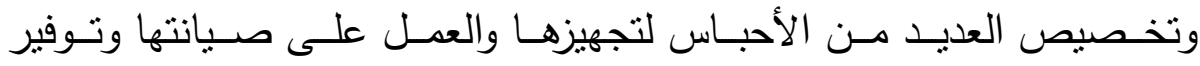

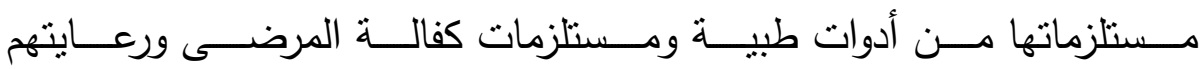

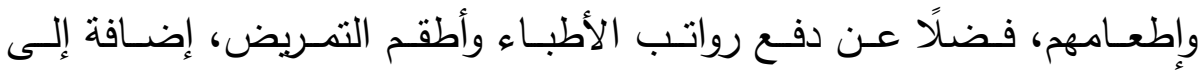

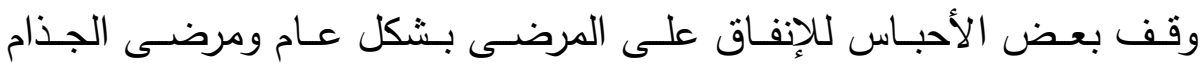

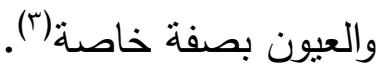

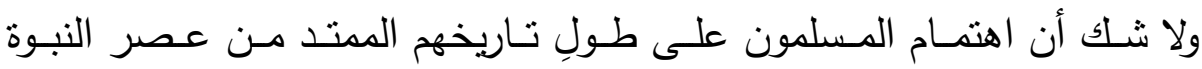

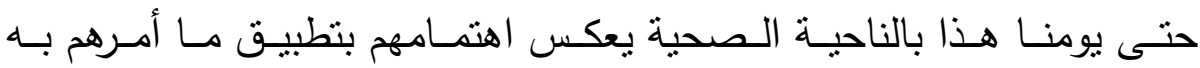

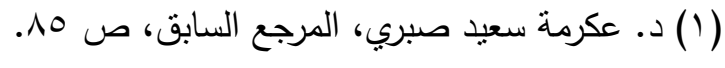

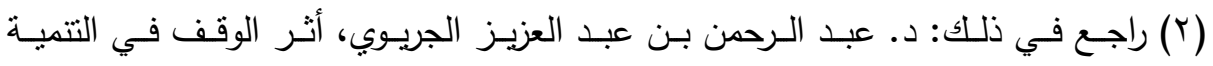

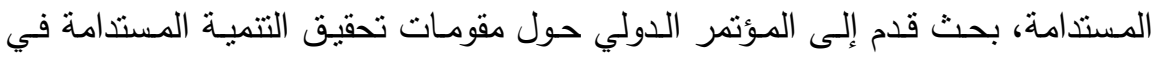

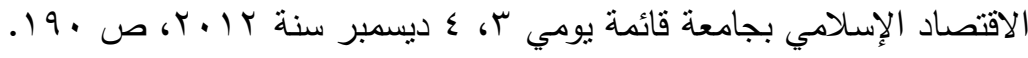

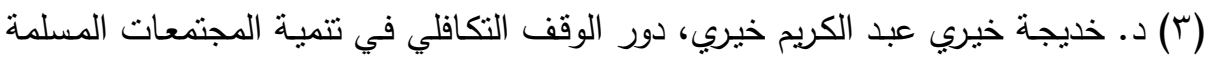

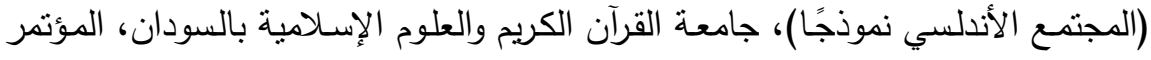

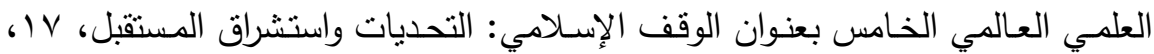




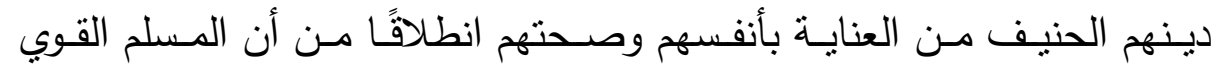

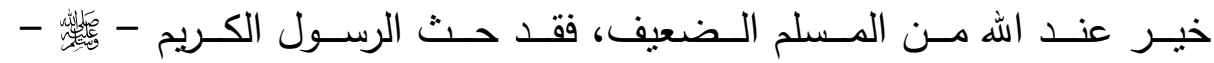

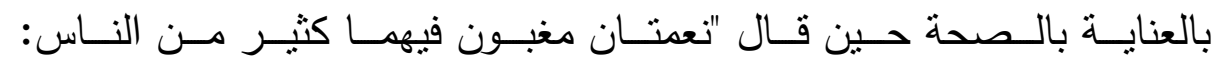

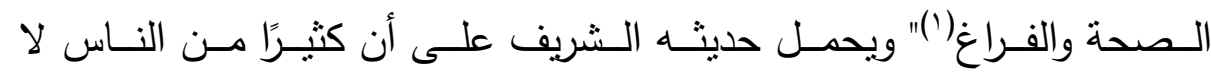

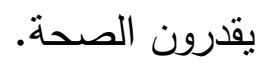

وعلى مـا تقدم اهتن المسلمون ببنـاء المستشفيات وأمـاكن الرعايـة الـصحية

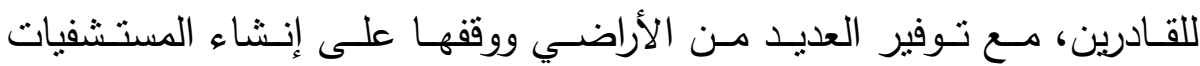

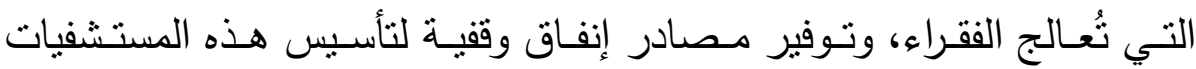

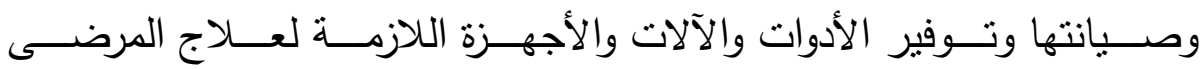

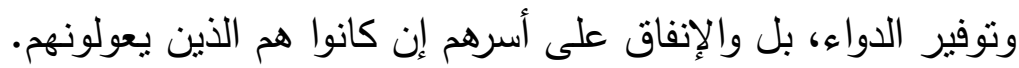

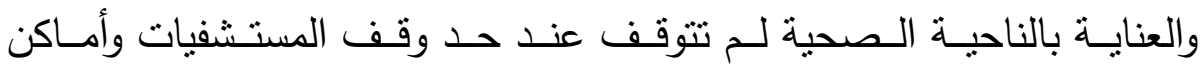

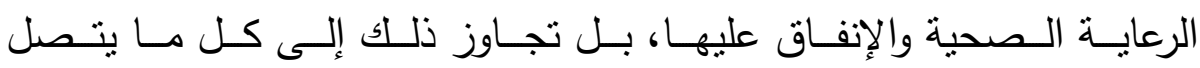

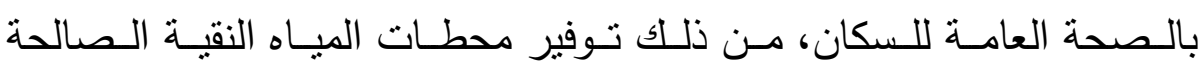

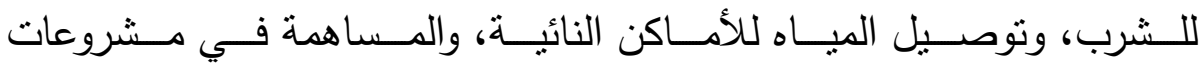
الصرف الصحي للقرى والنجوع الأقل دخلًا. 


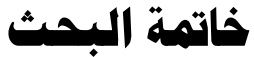

\section{(النتائج والتوصيات)}

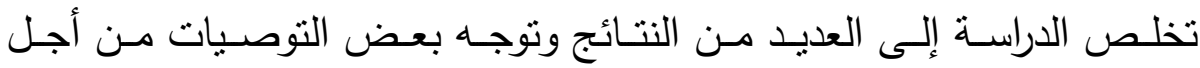

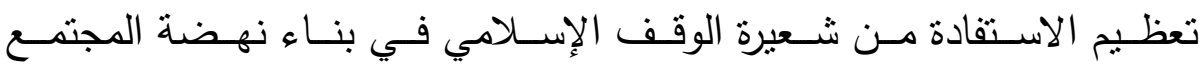

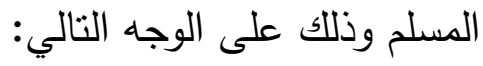

\section{أولاً النتائج:}

يخلص البحث إلى العديد من النتائج المهمة أهمها:

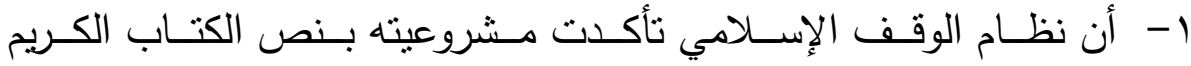

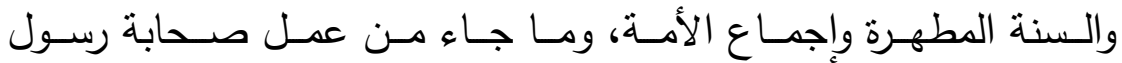

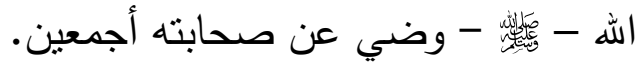

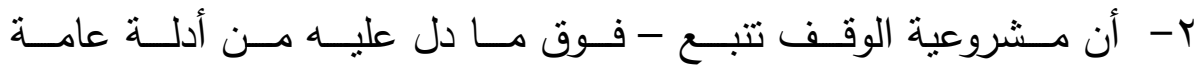

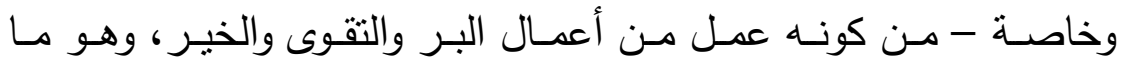

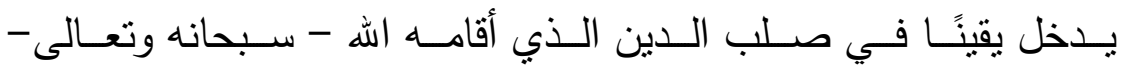
على فعل الخيرات وتجنب الثرور والمعاصي.

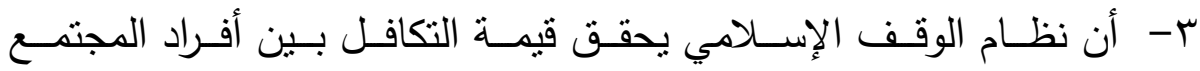

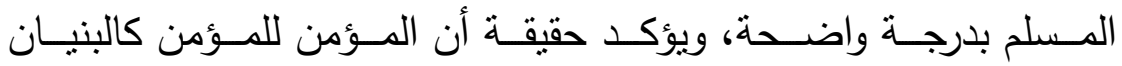

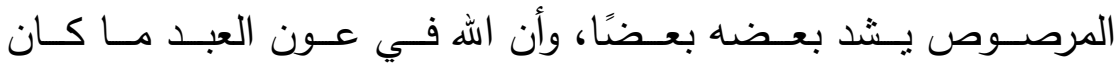

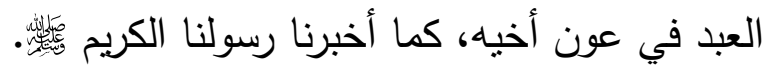

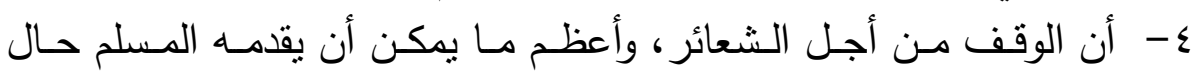

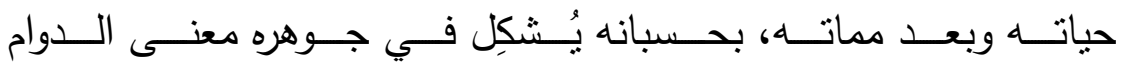

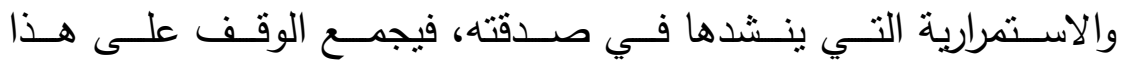

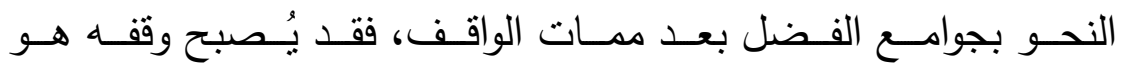

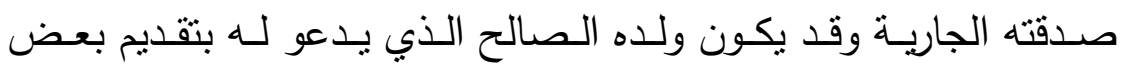

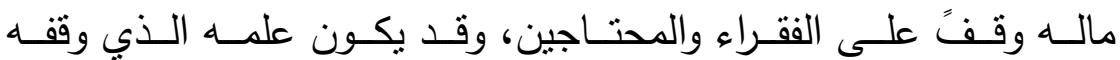
بمدرسته أو جامعته أو مكتبته كي يُنتفع به بعد ماءله وماته. 


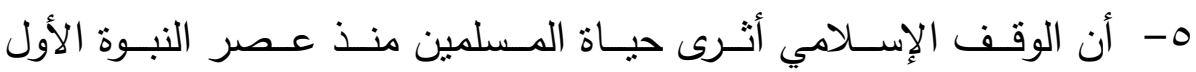

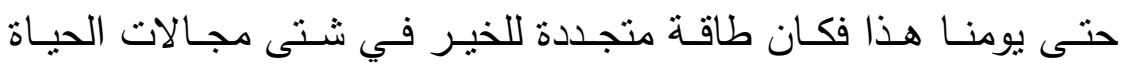

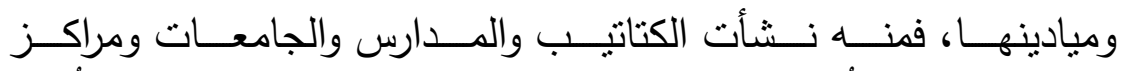

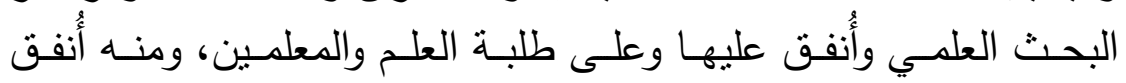

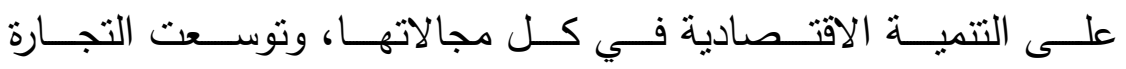

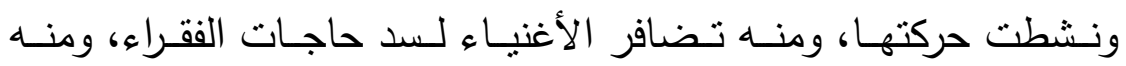

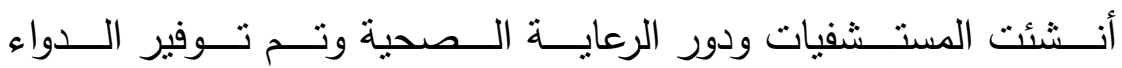
للمرضى من المحتاجين.

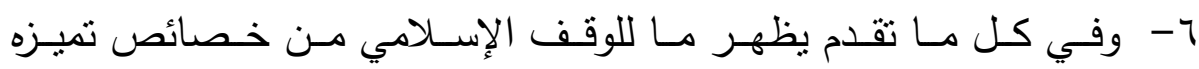

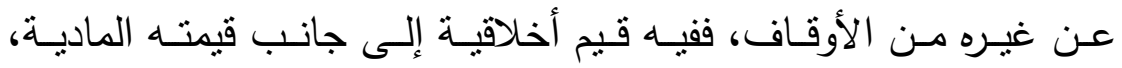

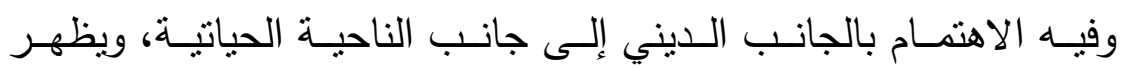

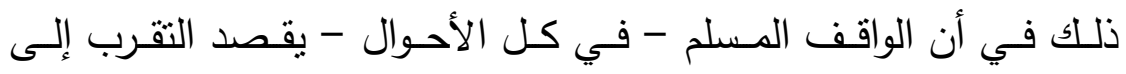
الله بعمله ووقفه الذي يقدمه حسبة له.

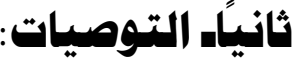

يمكن أن نوصي في هذا المقام ببعض التوصيات ومنها:

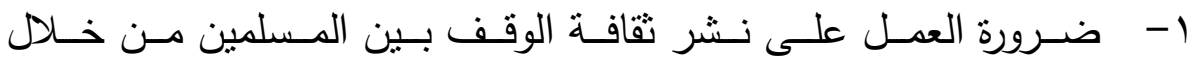

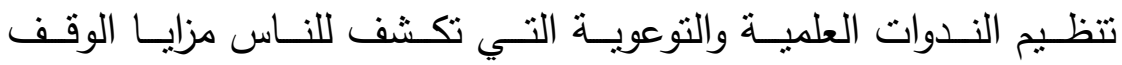

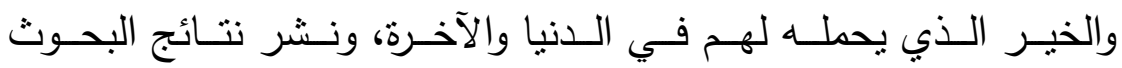

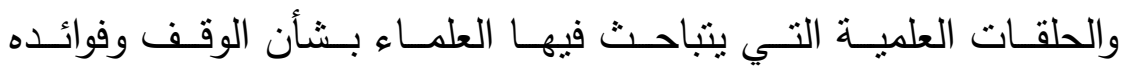

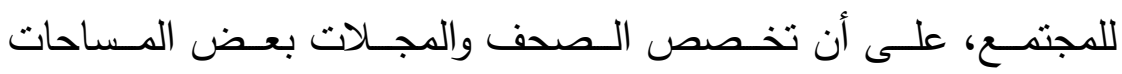

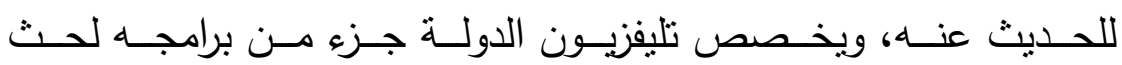

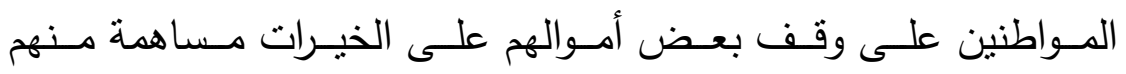

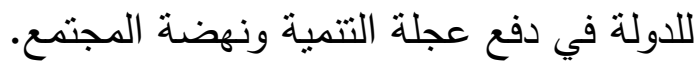

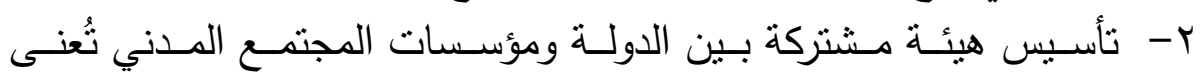

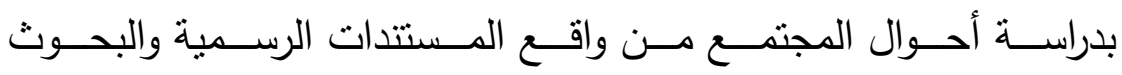


الواقعيـة لتحديـد الجوانـب الاقتــصادية والـصحية والاجتماعيـة والعلميـة

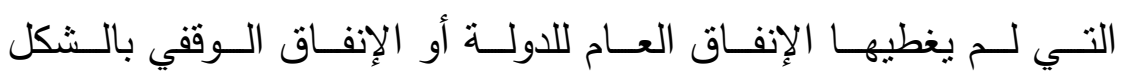

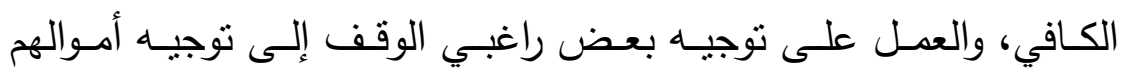

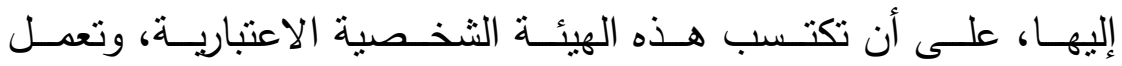

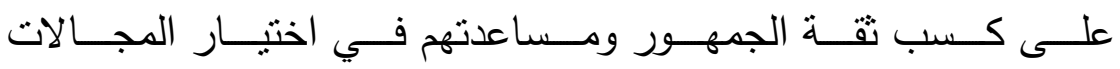
المجتمعية الأوفق لتمويل مشروعاتها.

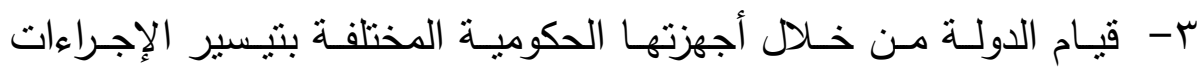

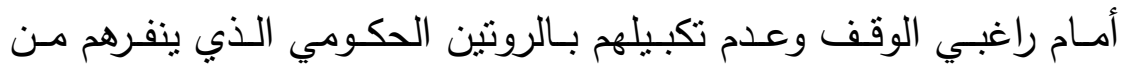

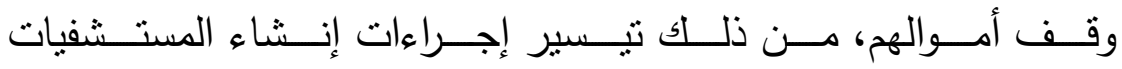

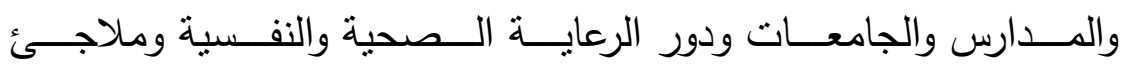
الأيتام ودور المسنين، وتوفير الأثناث والأدوات اللازمة لها.

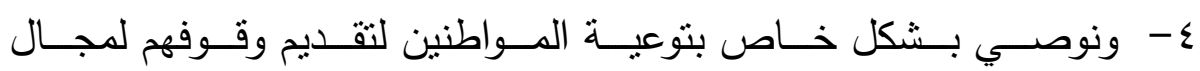

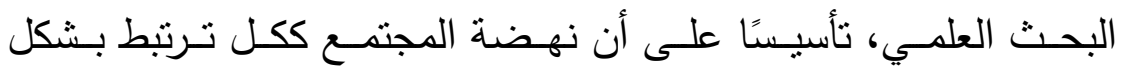

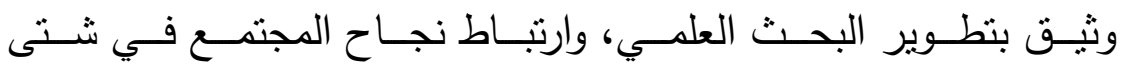
ميادين الحياة بإقامة العمل فيها على العلم والأخذ بأدواته ونتائجه.

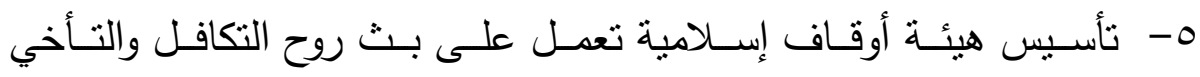

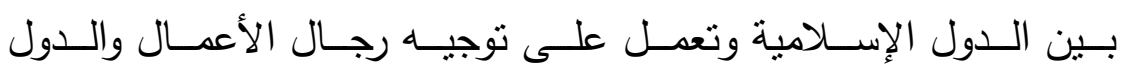

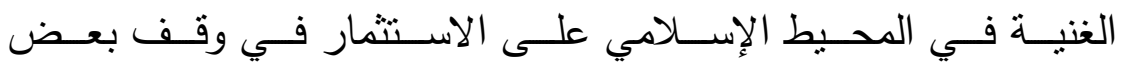

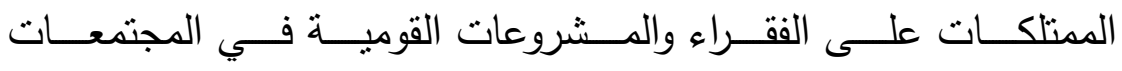
المسلمة خاصة الفقيرة منها.

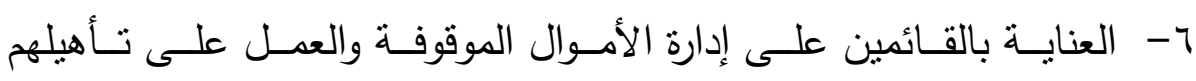

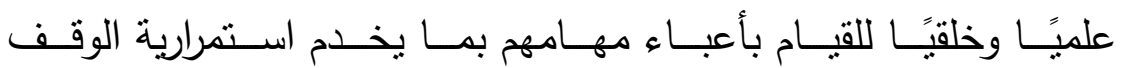

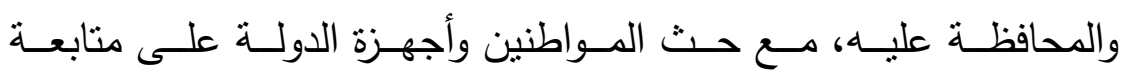
عملهم وتثجيعهم على الجد والاجتهاد فيه.

\section{ill}




\section{(قائسمة المراجع)}

\section{أولًا القرآن الكريم.}

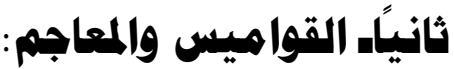

- محمد بن مكرم ابن منظور، معجم لسان العرب.

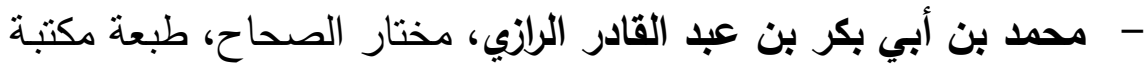

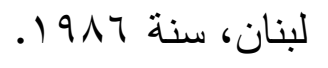

- محمــ بـن يعقـوب الفيـروز آبـادي، القاموس المحيط، دار الحديث

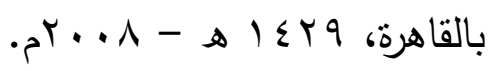

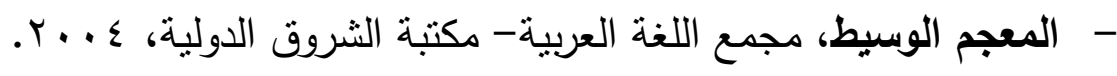

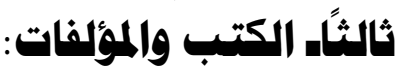

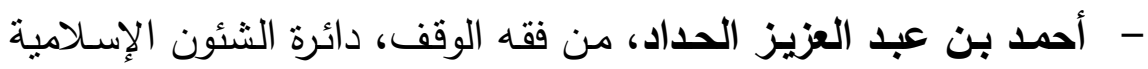

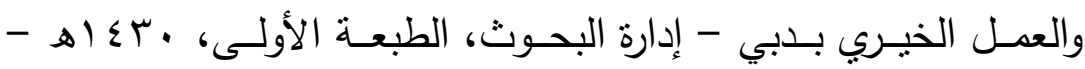

$$
\text { . } 9
$$

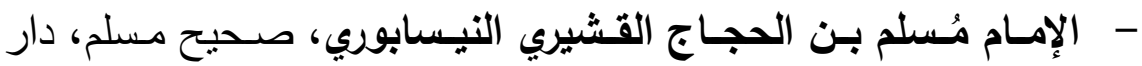

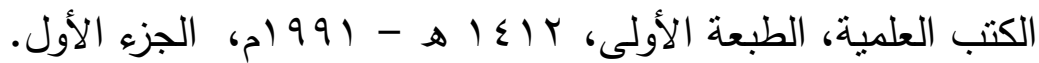

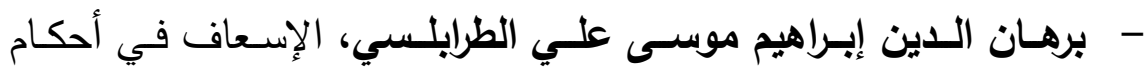

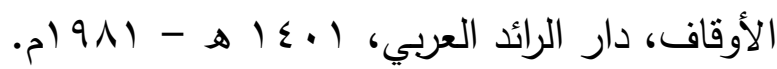

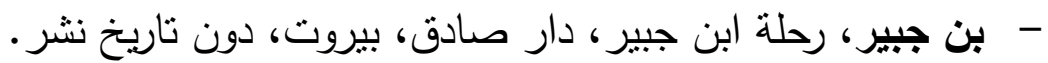

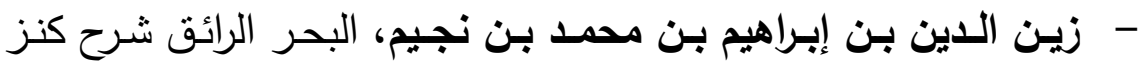

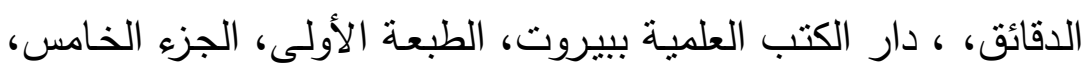

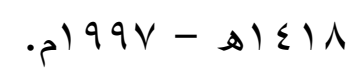

- سليم منصور، الوقف ودوره في المجتمع الإسلامي المعاصر، مؤسسة

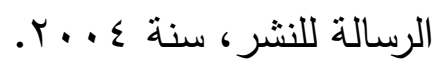

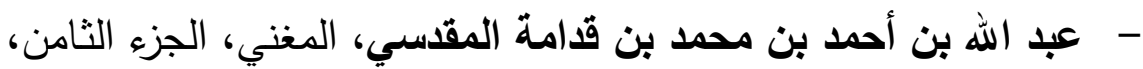

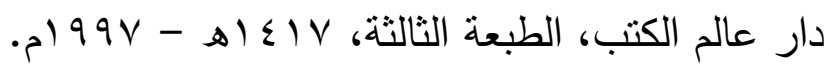


-

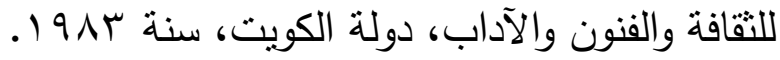

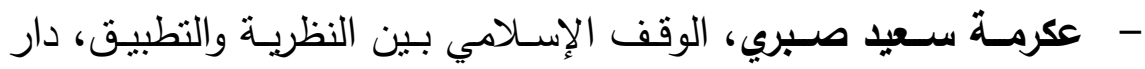

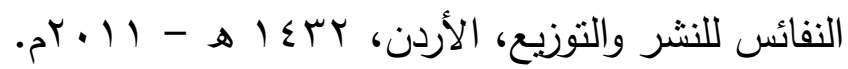

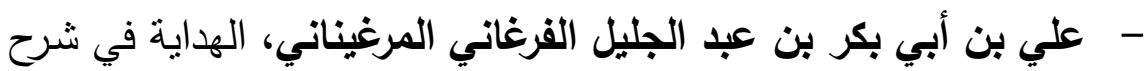

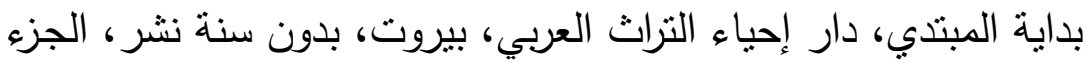

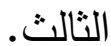

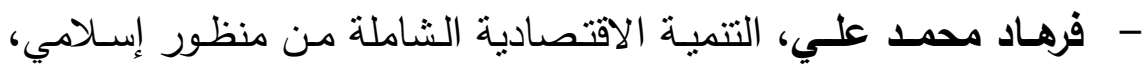

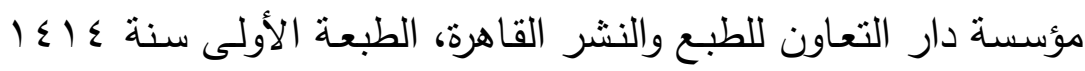
.

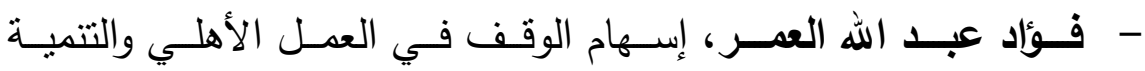

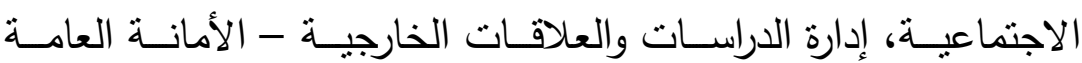

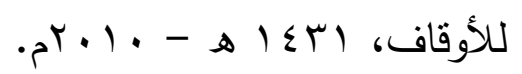

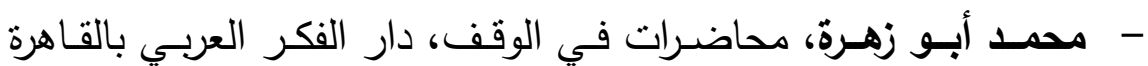
$.19 \times 1$ - محمد الفاتح محمود، اقتصاديات الوقف، دار الجنان للنشر والتوزيع، $. r \cdot 1 \leqslant$ - محمد بن أحمد بن أبي بكر القرطبي، الجامع لأحكام القرآن (تحقيق د.

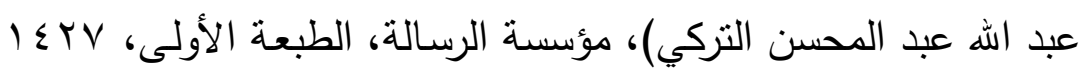
هـ - ؟ . . بام، الجزء الخامس.

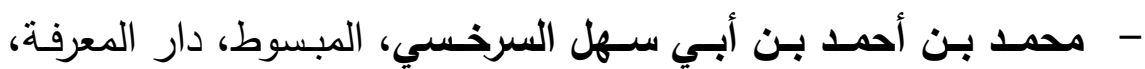

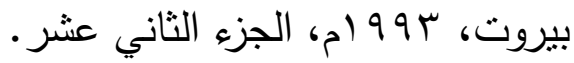

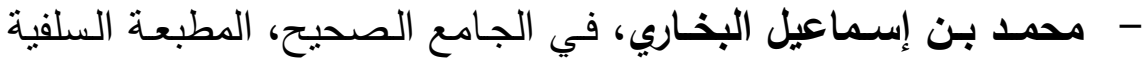

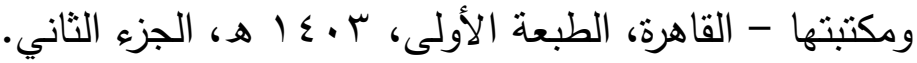

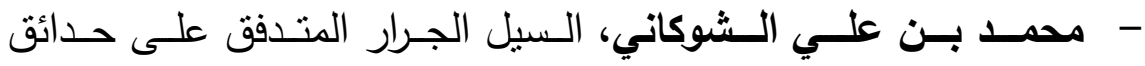

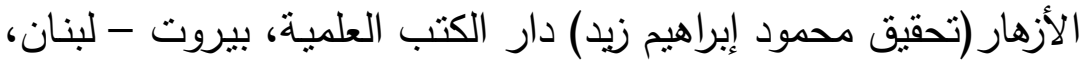

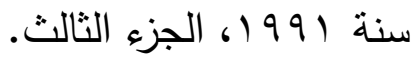


- محمد بن محمد بن عبد الكريم بن عبد الواحد الثيياني (ابن الأثير)،

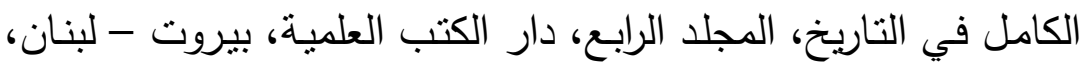

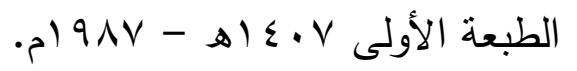

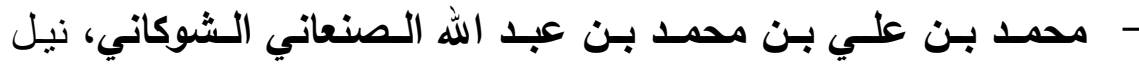

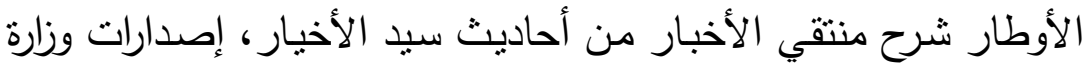

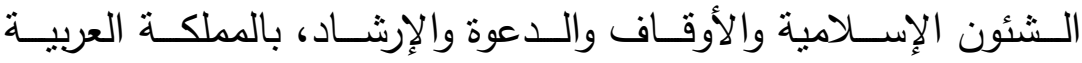

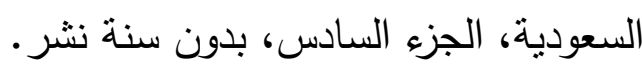

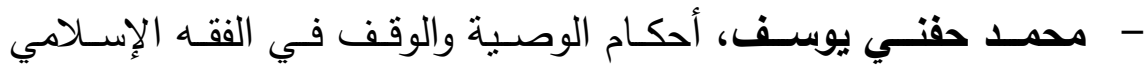

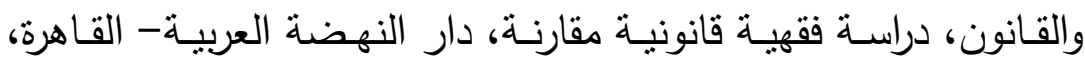

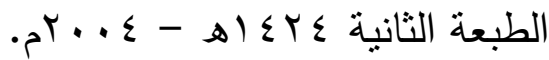
- محمد عبد العزيز عجيبة، إيمان عطية ناصف، على عبد الوهاب نجا،

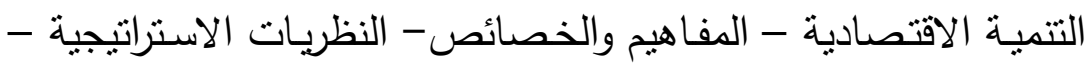

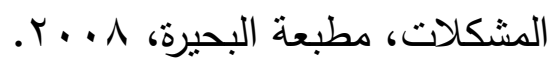

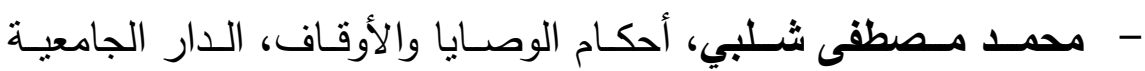

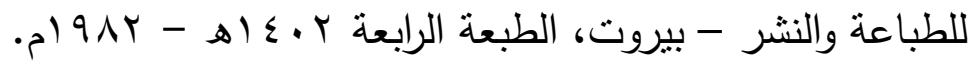
- - المرداوي، الإنصاف في معرفة الراجح من الخلاف، الجزء السابع.

- حسين عبد المطلب الأسـرج، الوقف الإسـامي كآلية لتمويل وتتميـة

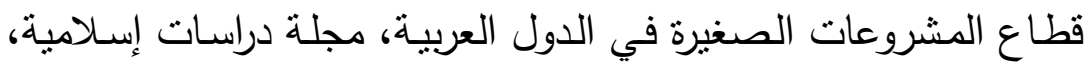

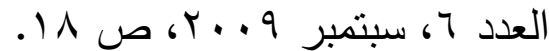

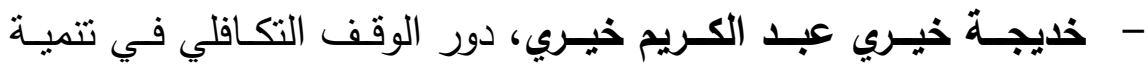

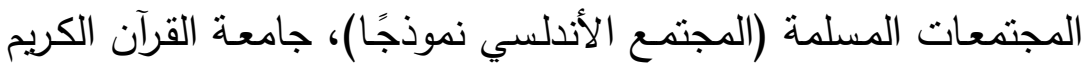

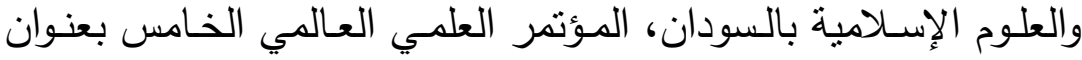

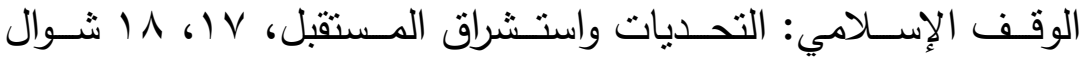

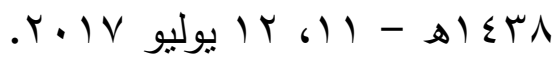


- دلالـي الجيلالـي، دور الوقف في النهضة العلمية والثقافية- قراءة في

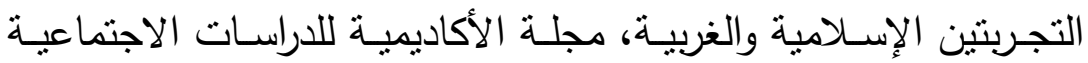

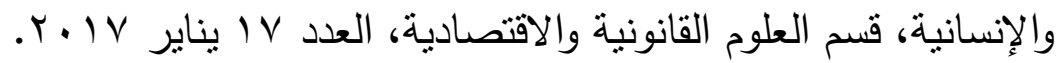

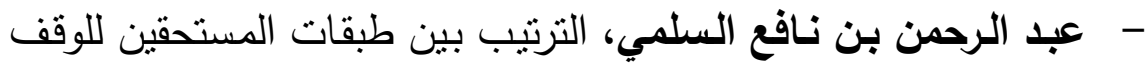

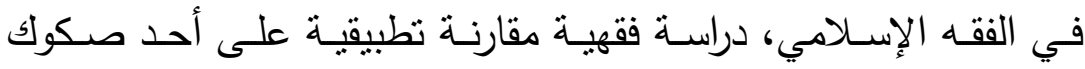

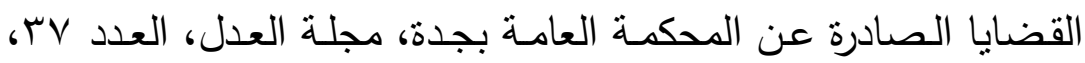

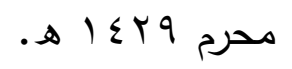

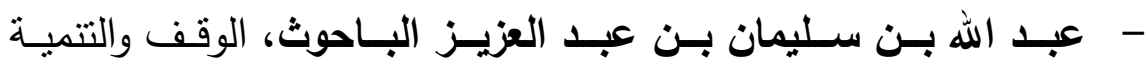

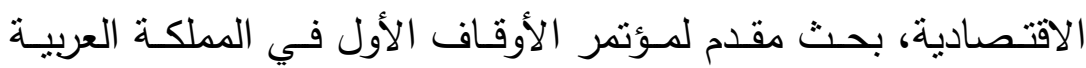

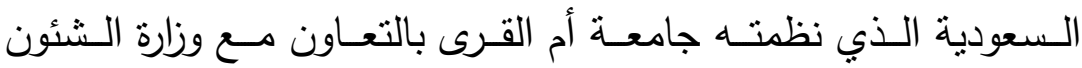

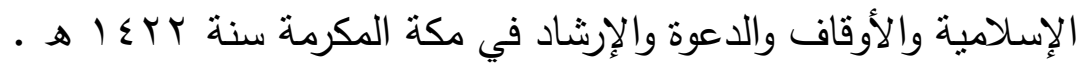

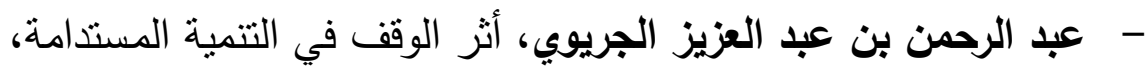
بحث قدم إلى المؤتمر الدولي حول مقومات تحقيق التنمية المستدامة في

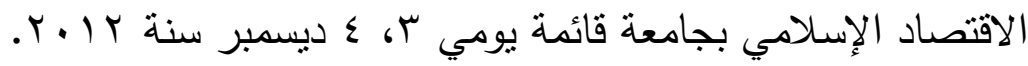

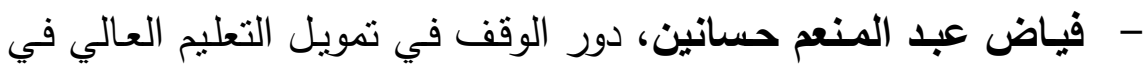

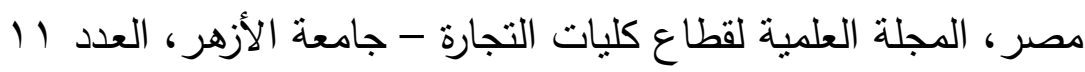

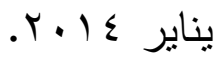
- كامل محمد حسين حامد، اثر الوقف في دعم وتطوير التعليم الشرعي

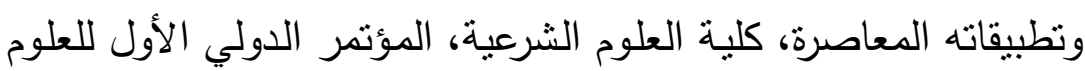

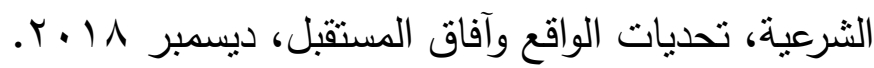

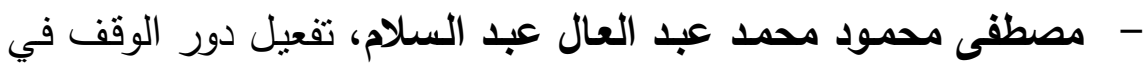

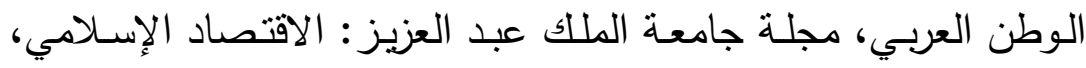

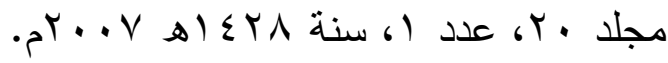

